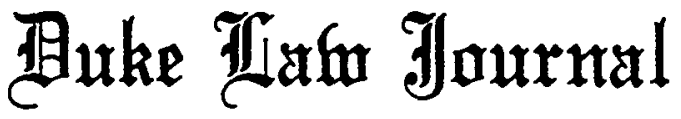

\begin{tabular}{lll}
\hline VOLUME 1983 & February & NUMBER 1 \\
\hline
\end{tabular}

\section{THE STATUS OF DEFRAUDED SECURITYHOLDERS IN CORPORATE BANKRUPTCY}

\author{
KENNETH B. DaVIS, JR.* \\ INTRODUCTION
}

Suppose an investor, six months ago, bought a block of shares in a public offering by a booming high technology firm. The firm's pubhished financial reports and its registration statement depicted strong past and potential earnings growth. The reports were largely fabrications, however, and yesterday, as the firm filed for reorganization under the bankruptcy laws, it became obvious that its assets would not satisfy ordinary creditors' claims, much less leave any residual equity for shareholders. Consequently, the investor files a class action against the firu and its management ${ }^{1}$ seeking rescission and damages under the federal securities laws.

Even if the investor were to win in court or obtain a settlement, ${ }^{2}$ he

- Assistant Professor of Law, University of Wisconsin Law School.

Support for this research was provided by the Antone L. Sinongeski Bequest, administered by the University of Wisconsin Foundation. The author wishes to thank Professor William C. Whitford, who provided valuable comments on an earlier draft, and Professor Ronald J. Coffey, who generated the author's interest both in the general area of securities regulation and in the specific topic of this article and who has provided invaluable assistance and encouragement along the way. The author also expresses his appreciation to the staff of the Washington \& Lee University Law Library for its help in researching Bankruptcy Code legislative history materials included in the papers of Congressinan $M$. Caldwell Butler.

1. Possible defendants include directors, officers, outside lawyers and accountants. See generally \& II(a) of the Securities Act of 1933, 15 U.S.C. \& 77k(a) (1976); \& 10(b) of the Securities Exchange Act of 1934, 15 U.S.C. $\$ 78 \mathrm{j}(\mathrm{b})$ (1976), as implemented by Rule 10b-5, 17 C.F.R. \$240.10b-5 (1982).

2. Actual hitigation of the securities law claims against the firm will be suspended as a result of the automatic stay in bankruptcy. See Bankruptcy Code $\$ 362(a)(1),(7)$, 11 U.S.C. \$362(a)(1),(7) (Supp. V 1981). The investor may petition to have the stay lifted, however, and may participate in the reorganization proceedings in the hopes of obtaining provision for his claims in the reorganization plan. 
may face great difficulty in recovering any money from the firm itself. The firm's general creditors will argue that, as a shareholder, the investor accepted the risks of an equity position in return for an opportunity to participate in profits. The creditors will contend that it is unfair to let the investor shed this risk and seek general creditor status because of bankruptcy. The investor will argue that general maxims of bankruptcy give a debtor's unsecured creditors equal footing in recovery, whether their claims sound in tort, breach of contract, or some other cause of action; therefore, why should shareholder fraud victims receive different treatment from that accorded other tort claimants, such as a pedestrian hit by the bankrupt's delivery truck? This latter argument has been advocated on behalf of the investor by the Securities and Exchange Commission. ${ }^{3}$

Given the recurring nature of problems resembling those presented in this hypothetical, ${ }^{4}$ it is not surprising that Congress sought to resolve these problems by statute when it enacted the coinprehensive Bankruptcy Reform Act of 1978.5 The congressional solution 6 was to

3. See, eg., Memorandum for the Securities \& Exchange Commission, at 19 n.19, Protective Comm. v. Anderson, 390 U.S. 414 (1968); Securmties \& Exchange Comm., Report on S.235 AND S.236, reprinted in The Bankruptcy Reform ACt, Hearings on S.235 and S.236 Before the Subcomm in Improvements in Judicial Mach of the Senate Comm on the Judiclary, 94th Cong., Ist Sess. $738-79$ (1975). [hereinafter cited as SEC REPORT ON BANKRUPTCY REvISION, 1975 Senate Hearings]. The latter report represented the SEC's views on the legislation eventually enacted as the Bankruptcy Reform Act of 1978, Pub. L. No. 95-598, 92 Stat. 2549 (1978). The House of Representatives received a similar report, reprinted in Bankruptcy Act Revision: Hearings on H.R. 31 and H.R. 32 Before the Subcomm on Civil and Constitutional Rights of the House Comm. on the Judiciary, 94th Cong., 2d Sess. 2164-2208 (1976) [hereimafter cited as SEC REPORT ON BANKRUPTCY REVISION, 1976 House Hearings]. The discussion of securities law claims subordination is identical in the two reports. See SEC REPORT ON BANKRUPTCY REviSION, 1975 Senate Hearings, supra, at 759-60; SEC REPORT ON BANKRUPTCY REVISION, 1976 House Hearings, supra, at 218486.

4. Examples include the reorganizations of Westec Corp., Four Seasons Nursing Centers of America, Inc., and Equity Funding Corp. of America; the liquidation of Stirling Homex Corp.; and two of the largest bank failures in the country's history, Franklin Nat'l Bank in New York and United States Nat'1 Bank in San Diego. Securities law class actions are currently pending in connection with the reorganizations of AM Int'l Inc., Itel Corp., Lionel Corp., Saxon Industries and Wickes Companies. In 1975 the SEC noted that $40 \%$ of the Chapter X reorganizations in which it entered an appearance between 1972 and 1974 involved a concurrent or antecedent SEC action under the securities laws. See SEC Report ON BANKRUPTCY REvision, 1975 Senate Hearings, supra note 3, at 760 n.48; SEC REPORT ON BANKRUPTCY REVISION, 1976 House Hearings, supra note 3 , at $2185 \mathrm{n} .48$ (22 of 55 reorganizations).

5. Pub. L. No. 95-598, 92 Stat. 2549 (1978). In general the act applies to proceedings coinmenced on or after October $1,1979$.

6. Congress accepted the recommendation of the Commission on the Bankruptcy Laws of the United States on this point. The Commission, created by Congress in 1970 to undertake a comprehensive reform of the bankruptcy laws, issued its final report on July 30, 1973. REPORT OF the COMmission ON the BANKRUPTCY LAWS OF tHe UNITED STATES, H.R. DOC. No. 93-137, 93d Cong., 1st Sess. (1973). Part II of the report sets forth the text of the Commission's proposed 
mandate a blanket subordination of securitics laws claims in section 510(b) of the new Bankruptcy Code:

Any claim for recission [sic] of a purchase or sale of a security of the debtor or of an affiliate or for damages arising froin the purchase or sale of such a security shall be subordinated for purposes of distribution to all claims and interests that are senior or equal to the claim or interest represented by such security. ${ }^{7}$

In the reorganization of a large, publicly held corporation, the allocation of millions of dollars may turn on whether securities law claimants can participate as general creditors. In terms of the goals of contemporary securities regulation, the subordination doctrine goes to the heart of the compensatory objective enbodied in the various securities law remedies. Although such remedies have proven valuable to securityholders in a great many cases in which the issuer was solvent, it is the bankruptcy cases in which the fraud is likely to be the most acute and the fraud-caused losses to sccurityholders the greatest. ${ }^{8}$

This article criticizes Congress' decision in favor of subordination. Part I traces the historical developinent of the subordination doctrine and examines the events leading to its codification in the Bankruptcy Reform Act of 1978. Part II considers both traditional and new arguments supporting the doctrime and concludes that these rationales do not justify subordination of a shareholder's otherwise valid claim for loss in investment value attributable to the fraud. Part III then considers how to allocate the total fraud-caused loss in the investment value of the firm between its debt and equity claimants. It concludes that a rule of parity-that is, permitting securities law claimants to participate

statute [hereinafter cited as Commission Proposal], entitled the "Bankruptcy Act of 1973," which provides the basis for the Bankruptcy Reform Act of 1978. Section 4-406(a)(1) of the Commission Proposal provided for subordination of securities law claims. See infra note 43 and accompanying text.

The Commission's recommendation regarding securities law claims appears to have generated little outside interest during the legislative consideration of the Bankruptcy Reform Act. This comes as something of a surprise given the recurring nature of the issue and the amount of money typically at stake. Other than the SEC, there were no strong critics of the subordination proposal. Several groups made comments on the proposal, but it is a fair conclusion from a review of their statements and testimony that these groups did not attach a particularly high priority to it. The typical treatment of $84-406$ (a)(1) was one sentence in a multi-page statement, submitted by an imterested group, saying without elaboration that the group favored subordination.

7. 11 U.S.C. $\$ 510$ (b) (Supp. V 1981). Throughout this article, the new bankruptcy law, codified at 11 U.S.C. \$8101-151,326 (Supp.V 1981), will be referred to as the "Bankruptcy Code." The predecessor bankruptcy law, codified at 11 U.S.C. \$81-1103 (1976), will be referred to as the "Bankruptcy Act."

8. Furthermore, in bankruptcy cases the issuer is inore likely to be the sole viable defendant for recoveries. It is easier to recover a judgment from the officers of a solvent company than from the officess of Equity Funding, Stirling Homex, or Four Seasons. See infra note 150 and accompanying text. 
on a par with other unsecured creditor claimants-produces allocations that are better for public policy and fairer than the allocations produced by the subordination doctrine. This conclusion is qualified, however, by the requirement that the ineasure of the securities law claims entitled to parity should be limited to the amount of fraud-caused loss. ${ }^{9}$

\section{BaCkground of THE SUbordination Doctrine}

\section{A. The Development of an American Rule.}

In adopting section 510 (b) Congress did not write on a clean slate; for over one hundred years judges have directed considerable attention to the conflict between an insolvent issuer's creditors and defrauded shareholders. Early cases typically involved shareholders' attempts to rescind in order to escape liability on their shares, as opposed to the efforts of modern shareholders to rescind so as to participate in the allocation of the issuer's assets. In these early cases, the British courts held-based in part on language in the then applicable companies statute ${ }^{10}$ - that a shareholder lost any right to rescind his subscription for fraud once winding-up proceedings began. ${ }^{11}$ In effect, wimding up "crystallized" the fraud victim's status as a shareholder. ${ }^{12}$

The earhest American cases followed this British lead and regularly denied relief to the shareholder. ${ }^{13}$ As Judge Dillon, later a prominent New York corporate lawyer, concluded in one of these cases, "[t]hese [British] decisions are doubtless in some degree infiuenced by the special provisions of the compamies' act, particularly that of 1862 , but the general course of reasoning therein is applicable to cases of insolvent or bankrupt corporations in this country."14 Thus, lacking the statutory authority available to their British counterparts, American judges resorted to general principles of equity and then-developing conceptual notions about the fundamental-relationship between share-

9. This article is intended as the first part of a two-part project dealing with the treatment of securities law claims in bankruptey. The planned second part will examine the practical workings of section 510(b) and how to possibly implement the conclusions reached herein. For now, it should be noted that although the legal arguments presented in this article depict subordination and parity as black-or-white alternatives, the more realistic view is that they are cndpoints on a spectrum of potential results that may be produced through the bankruptcy reorganization bargaining process.

10. Companies Act, 1862, 25 \& 26 Vict., ch. 89.

11. The decision of the House of Lords settling this issue was Oakes v. Turquand, 2 L.R.-E. \& I. App. 325 (1867). See also Henderson v. Royal British Bank, 119 Eng. Rep. 1279 (Q.B. 1857) (similar result under earlier statute).

12. Hornby, Book Revicw, 71 Law Q. Rev. 415, 416-17 (1955).

13. It is difficult, but possible, to find a stray exception. See, e.g. , Litchfield Bank v. Peck, 29 Conn. 384 (1860).

14. Upton v. Englehart, 28 F. Cas. 835, 838 (C.C.D. Iowa 1874)(No. 16,800). 
holder and creditor in disallowing rescission. For exainple, many courts held that the shareholder had failed to prove his diligence in detecting the fraud or, upon discovering it, in repudiating his subscription. ${ }^{15}$ Other opinions seein sinuply to hold that after insolvency, as a matter of law, a shareholder could not invoke the fraud to avoid hability to the corporation's creditors. ${ }^{16}$

This early solicitude for creditors arose in part from the then-accepted theory that corporate capital comprised a "trust fund" for the payment of corporate debts. The iniplications of this theory were that creditors obtained solnething akin to an equitable charge against the "fund" represented by the shareholders' capital and could, therefore, limit withdrawal of the "fund" froin the corporation. ${ }^{17}$ Thus applied, the trust fund analogy represented a strong judicial reluctance to perinit intracorporate controversies or arrangeinents, such as the fraud of a corporate agent, to compromise the integrity of the firm's stated capital.

By the turn of the century, however, courts had begun to discard the broad trust fund analogy, focusing instead on creditor reliance. ${ }^{18}$ If the expectations of individual creditors deserved primary protection, the defrauded shareholder's right to relief needed limiting only to accommodate those expectations; only those creditors who could have rehed on the particular shareholder's subscription-generally creditors whose claims arose after the subscription-deserved a superior claim

15. See, e.g., Oglivie v. Knox Ins. Co., 63 U.S. (22 How.) 380, 390-91 (1860); Farrar v. Walker, 8 F. Cas. 1076, 1078 (C.C.E.D. Mo. 1875)(No. 4,679); Upton v. Englehart, 28 F. Cas. 835 (C.C.D. Iowa 1874)(No. 16,800); Howard v. Tumer, 155 Pa. 349, 26 A. 753 (1893); Weisiger v. Richmond-Ice Mach. Co., 90 Va. 795, 20 S.E. 361 (1894).

16. See, eg., Michener v. Payson, 17 F. Cas. 259 (C.C.E.D. Pa. 1875)(No. 9,524); Howard v. Glenn, 85 Ga. 238, 11 S.E. 610 (1890); Dettra v. Kestner, 147 Pa. 566, 23 A. 889 (1892).

17. See, eg., Sanger v. Upton, 91 U.S. 56, 60 (1875):

The capital stock of an incorporated company is a fund set apart for the payment of its debts. It is a substitute for the personal liability which subsists in private copartnerships. When debts are incurred, a contract arises with the creditors that it shall not be withdrawn or applied, otherwise than upon their demands, until such demands are satisfied. The creditors have a lien upon it in equity. If diverted, they may follow it as far as it can be traced, and subject it to the payment of their claims, except as against lolders who have taken it bona fide for a valuable consideration and without notice. It is publicly pledged to those who deal with the corporation, for their security.

Credit for originating the principle belongs to Justice Story, writing as Circuit Justice in the case of Wood v. Dummer, 30 F. Cas. 435 (C.C.D. Me. 1824)(No. 17,944), in whicls a bank distributed assets equal to three-quarters of its capital stock to shareholders. The distribution rendered the bank insolvent. Adopting the trust analogy, the court permitted creditors to follow the assets into the hands of shareholders and recover from them. For discussions of the trust-fund doctrine in fraud cases see Upton v. Tribilcock, 91 U.S. 45 (1875); Fear v. Bartlett, 81 Md. 435, 32 A. 322 (1895) (doctrine does not apply unless corporation dissolved or insolvent).

18. The doctrinal. vagaries of the trust fund analogy led to its ultimate rejection. See generally B. Manning, A Concise Textbook on Legal. Capital 46 (2d ed. 1981); Hunt, The Trust Fund Theory and Some Substitutes For It, 12 YALE L.J. 63 (1902); Warren, Safeguarding the Creditors of Corporations, 36 HARv. L. REv. 509, 544-46 (1923). 
on the capital contributed by that shareholder. ${ }^{19}$ Thus, by the 1930s, the dominant rule in this country allowed the shareholder to rescind, even after insolvency. The courts then simply deferred his claim to any claims by persons who extended credit after, and presumably in reliance on, his subscription..$^{20}$ Usually, however, the claims of subsequent creditors consumed the corporation's remaming assets, so the sharelolder often fared no better under the einerging American doctrine than under its English predecessor. ${ }^{21}$

Nevertheless, various procedural niceties made possible by this doctrinal change aided the American shareholder. One leading opinion suggested that, at least in the case of trade creditors whose relationship with the corporation predated the subscription at issue, additional evidence of reliance in combination with subsequent credit was necessary to establish reliance on the subscription. ${ }^{22}$ Moreover, the courts of several jurisdictions held that because the basis for deferring the shareholder's claim was creditor reliance, a matter peculiar to individual creditors, a receiver, who theoretically stood in the shoes of the corporation, could not assert the creditor's position. ${ }^{23}$ Thus, the American

19. Probably the most influential decision was Newton Nat'l Bank v. Newbegin, 74 F. 135 (8th Cir. 1896). In a review of prior law, the court noted that every case denying a right to rescind had involved either a shareholder failing to act diligently, a shareholder actively participating in management of the corporation, or debts contracted by the corporation after the subscription. Thus the court held that when no considerable amount of corporate indebtedness had been created since the subscription had been made, rescission should be allowed even after insolvency. Id. at 140. This focus on subsequent creditors and departure from the trust analogy closely paralleled the more celebrated rejection of the trust fund doctrine in the context of hability for watered stock. See Hospes v. Northwestern Mfg. \& Car Co., 48 Minn. 274, 50 N.W. 1117 (1892).

20. See, eg., MacNamee v. Bankers' Union for Foreign Commerce \& Fin., Inc., 25 F.2d 614 (2d Cir. 1928); Jagels v. Cox, 50 Idaho 67, 294 P. 515 (1930); Burningham v. Burke, 67 Utah 90, 245 P. 977 (1926); Atwood v. McKenzie-Waterhouse Co., 120.Wash. 214, 206 P. 978 (1922). For comprehensive collections of American cases on the question, see Annot., 41 A.L.R. 674 (1926); Annot. 46 A.L.R. 484 (1927); 4 W. FletcheR, CyClopedia of the LAW of Private CoRporaTIONS \$\$1707-1721 (perm. ed. 1965).

21. See, e.g., In re Morris Bros., Inc., 282 F. 670 (D. Ore. 1922), affd, 293 F. 294 (9th Cir. 1923); Lex v. Selway Steel Corp., 203 Iowa 792, 206 N.W. 586 (1925).

22. Burningham v. Burke, 67 Utah 90, 111-15, 245 P. 977, $985-86$ (1926). Professors Dodd and Baker have noted that this case was settled upon remand; thus, the quantun of additional evidence necessary was presumably never litigated. E. M. DODD \& R. BAKER, CASES AND MATERIALS ON CORPORATIONS 760 ( $2 \mathrm{~d}$ ed. 1951).

23. The doctrine applied whether the receiver sought to collect an unpaid subscription or to resist restitution of the paid purchase price. See Florida Land \& Improvement Co. v. Merrill, 52 F. 77 (5th Cir. 1892); People v. California Safe Deposit \& Trust Co., 19 Cal. App. 414, 126 P. 516 (1912); Marion Trust Co. v. Blish, 170 Ind. 686, 84 N.E. 814 (1908); Kentucky Mut. Ins. Co.'s Assignee v. Schaeffer, 120 Ky. 227, 85 S.W. 1098 (1905); Harn v. Smith, 85 Okla. 137, 204 P. 642 (1921). See generally S. Hioh, A TREATISE ON THE LAW OF ReCEIVERS $\$ \$ 245,315$ (4th ed. 1910); RESTATEMENT OF RESTITUTION $\& 173$ comment $j$ (1937). Sone courts did adopt a contrary rule allowing the receiver to assert the rights of individual creditors as well as those of the corporation. See Lex v. Selway Steel Corp., 203 lowa 792, 206 N.W. 586 (1925); Grand Rapids Trust Co. v. 
rule not only provided the defrauded shareholder an opportunity to litigate the merits of his fraud claim in the bankruptcy proceeding, it also allowed him to raise procedural obstacles that may have significantly improved his settlement position. And in the few cases in which corporate assets could pay general creditor claims in full, it gave him priority over his nonvictimized counterparts. ${ }^{24}$

\section{B. The Oppenheimer decision .}

By the first part of this century, the American rule had achieved acceptance in most United States jurisdictions. Because of eventual economic prosperity and rising stock markets, and because of the long dry spell in private actions under the federal securities laws, ${ }^{25}$ the rule was not directly relitigated for five decades. During these quiet years, however, one case, Oppenheimer v. Harriman National Bank and Trust Co. ${ }^{26}$ is worth noting because it provides the most recent Supreme Court language on the subordination question, language relied on by the Securities and Exchange Commission for its position prior to the enactment of section $510(\mathrm{~b})$.

Before 1937, shareholders in national banks were personally liable for bank obligations up to the par value of their shares. ${ }^{27}$ Accordingly, when the Harriman Bank failed in 1933, Oppenheimer, a shareholder of the bank, was assessed the full par value of his shares, which he duly paid into the receivership. He then sued to rescind his share purchase for fraud. ${ }^{28}$ The Court of Appeals for the Second Circuit reversed a

Geer, 233 Mich. 577, 207 N.W. 883 (1926); Burningham v. Burke, 67 Utah 90, 245 P. 977 (1926). There would seem to be little doubt concerning a trustee in bankruptcy's power to assert the rights of the subsequent creditors. See Bankruptcy Act $\$ \$ 70$ c, 70e, 11 U.S.C. $\$ 110(\mathrm{c})$,(e) (1976); Bankruptcy Code \$ 544, 11 U.S.C. \$ 544 (Supp.V 1981); In re Desnoyers Shoe Co., 210 F. 533, 539 (S.D. Ill. 1914), affd, 224 F. 373 (7th Cir. 1915); Grand Rapids Trust Co. v. Nichols, 199 Mich. 126, 165 N.W. 667 (1917).

24. As to the last point, see MacNamee v. Bankers' Union for Foreign Counmerce \& Fin., Inc., 25 F.2d 614 (2d Cir. 1928); Stalnaker v. Gum, 87 W. Va. 283, 104 S.E. 730 (1920). For an indication that the British rule was to the contrary see In re Hull \& County Bank (Burgess's Case), 15 Ch. D. 507 (1880).

25. See 3 L. Loss, Securmies Regulation $1684-92$ (2d ed. 1961).

26. 301 U.S. 206 (1937).

27. National Bank Act, ch. 106, § 12, 13 Stat. 102 (1864); Federal Reserve Act, ch. 6, § 23, 38 Stat. 273 (1913). Both statutes were repealed by Act of Sept. 8, 1959, Pub. L. No. 86-230, $\$ 7,73$ Stat. 457.

28. Oppenheimer chose this procedural course because the Supreme Court had earlier settled that a bank shareholder could not escape his statutory liability by pleading fraud. Lantry $v$. Wallace, 182 U.S. 536 (1901); Scott v. Deweese, 181 U.S. 202 (1901). For a comparable result with respect to a state statutory hability provision see Commissioner of Banks v. Cosmopolitan Trust Co., 253 Mass. 205, 148 N.E. 609 (1925). Consequently, Oppenheimer did not contest the statutory assessment and sought to recover only the amount paid for his shares. Brief for Petitioner at 4, Oppenheimer v. Harriman Nat'l Bank \& Trust Co., 301 U.S. 206 (1937). 
district court judgment which denied the rescission, but also held that Oppenheimer could collect his claim only from assets remaining after full payment of the bank's pre-insolvency creditors ${ }^{29}$-a result contrary to the law of two other circuits. ${ }^{30}$

In a unanimous opinion, the Supreme Court reversed the Court of Appeals for the Second Circuit on the subordination issue. Without alluding to the vast body of subordination case law outside of the national bank context, the Court disposed of the issue in less than one paragraph. ${ }^{3 i}$ Two special circumstances apparently influenced its decision. First, Oppenheimer had paid for his shares out of funds deposited at the bank, so that but for the purchase of the shares he would have remained a general creditor. Second, by paying both the par value for his shares and his statutory assessment, Oppenheimer had, in effect, acknowledged and fully discharged his entire liability to other Harriman Bank creditors. ${ }^{32}$ These circumstances and the general tenor of the Court's opinion leave little rooin for reading Oppenheimer as a general rejection of the American rule of subordination.

\section{The SEC, Slain and Kripke, and the Rebirth of Absolute Subordination.}

At about the same time as the Harriman Bank failure and Oppenheimer's suit, Congress enacted the federal securities laws which provide the principal source of modern shareholders' remedies. $^{33}$ Congress seemed to ignore, however, the subordination question-a point not lost on contenuporary commentators. ${ }^{34}$ Moreover, the ques-

29. Oppenheimer v. Harriman Nat'l Bank \& Trust Co., 85 F.2d 582 (2d Cir. 1936), rev'd, 301 U.S. 206 (1937).

30. Both the First and Third Circuits had permitted the bank shareholder to participate ratably with the bank's general creditors. Clark v. Boston-Continental Nat'1 Bank, 84 F.2d 607 (1st Cir. 1936) (claimant had been defrauded into accepting bank stock as collateral for a loan to a third party); Salter v. Williams, 244 F. 126 (3d Cir. 1917), oppeal dismissed, 250 U.S. 653 (1919).

31. Oppenheimer v. Harriman Nat'l Bank \& Trust Co., 301 U.S. 206, 208 (1937). The Court cited six cases in this portion of its opinion. These included the Salter and the two Clark cases referred to in supra note 30, as well as the Florida Land \& Improvement case mentioned in supro note 23 in connection with the receiver's power to assert the rights of individual creditors. The others were Richardson v. Oliver, 105 F. 277 (5th Cir. 1900), holding that a bank depositor-even though also a bank shareholder-could recover from the bank's receiver a deposit unade when the bank's officers knew of its insolvency, and Williams v. Green, 23 F.2d 796 (4th Cir. 1928), holding that in an action by a bank's receiver on a note given in payment of bank stock, the inaker could defend on the ground that $a$ bank officer had fraudulently induced the purchase and thus the bank had received the note with notice of the fraud.

32. See 301 U.S. at 214-15.

33. See Securities Act of 1933, 15 U.S.C. $\$ 877 a-77 a a$ (1976); Securities Exchange Act of 1934, 15 U.S.C. $\$ 878 \mathrm{a}-78 \mathrm{kk}$ (1976).

34. For example, one writer included in his list of criticisms of the Securities Act of 1933 that "bona fide bondholders, inerchandise creditors, and commercial bank creditors may have to share 
tion apparently was not actively litigated in the courts, at least in terms of producing reported opinions, until the late 1970s. ${ }^{35}$ Tle issue, however, did arise occasionally. A review of the Securities and Exchange Commission's Annual Reports reveals the presence of the issue, prior to the 1970s, in several corporate reorganizations under Chapter $\mathrm{X}$ of the former Bankruptcy Act. Under Chapter X the SEC played an active role in reorganizations; 36 it had the right to be heard on all matters arising in the proceeding, ${ }^{37}$ and if the claims against the debtor exceeded three million dollars, the judge was required to refer the plan of reorganization to the SEC for an advisory report prior to approving it. 38

Exercising its authority under these provisions, the SEC took the position that shareholder claims based on violations of the securitics laws had to be given parity with other unsecured claims ${ }^{39}$ and con-

the company's assets with common stockholders just because there was an unavoidable mistake in the [prospectus]." Seligman, Amend the Securities Act, 153 ATLantic Monthly 370, 379 (1934). Another suggested that the British unwillingness to extend statutory liability for inaccuracies in prospectuses to issuers, see Companies Act, 1929, 19 \& 20 Geo. 5, ch. 23, \& 37(1), stemined from a concern for the intervening rights of creditors. Barnett, The Securities Act of 1933 and the British Companies Act, 13 HaRv. Bus. Rev. 1, 8 (1934). In an article written the next year, Professor Kessler surveyed continental legal systems and noted a similar tendency to limit the shareliolder's right to rescission and damages against the corporation in the interests of corporate creditors. Kessler, The American Securities Act and its Foreign Counterparts: A Comparative Study, 44 Y ALE L.J. 1133, 1156-62 (1935). In contrast, section 11 of the American Securities Act of 1933, 15 U.S.C. 877k (1976), which was otherwise closely modeled on the British statute, see Companics Act, 1929, 19 \& 20 Geo. 5, ch. $23, \& 37$, not only included the issuer among a long list of prospective defendants, including directors, certain officers of the issuer, underwriters and various experts, see 15 U.S.C. \& 77k(a)(1)-(5) (1976); of. Companies Act, 1929, 19 \& 20 Geo. 5, ch. 23, \& 37(1) (liability only for directors, promoters, and persons who authorize the issue of the prospectus), but also made the issuer's liability the strictest of all by denying it "due diligence" and other defenses, Securities Act \& 11(b), 15 U.S.C. \$77k(b) (1976). In addition, section 12 of the Act, 15 U.S.C. $\$ 77 l$ (1976), allows a purchaser of securities to recover from his immediate seller, which in a given case may be the issuer.

35. The lone exception is SEC $v$. Insurance Investors Trust Co., [1971-1972 Transfer Binder] FED. SEC. L. REP. (CCH) 93,259 (W.D. Ky. 1971), involving the receivership of an unregistered investment coinpany. Relying on the Oppenheimer decision and influenced in part by the apparent indifference of the investment coinpany's other creditors, the court held that purchasers of the company's shares, if successful on the merits of their claims under the securities laws, could participate in the assets of the receivership as general creditors.

36. Relying on the Suprenne Court's opinion in SEC v. American Trailer Rentals Co., 379 U.S. 594, 613 (1965), the SEC had also occasionally participated in arrangement proceedings under Chapter XI of the Bankruptcy Act when public investors were involved.

37. Bankruptcy Act \$207, 11 U.S.C. \& 608 (1976).

38. Otherwise, referral to the SEC was discretionary. Bankruptcy Act $\$ \$ 171-173,11$ U.S.C. $\$ \$ 571-573$ (1976).

39. See Memorandum for the Securities \& Exchange Commission, at 19 n.19; Protective Comm. v. Anderson, 390 U.S. 414, 437 n.19 (1968). 
tested plans that denied participation to such shareholder claims. ${ }^{40}$ More frequently the trustee-perhaps influenced by the prospect of SEC challenge-would compromise the defrauded shareholders' claims for a fraction of their face value. On this basis, shareholder fraud victims were permitted to share in the bankrupt corporation's assets despite its insolvency. ${ }^{41}$

In July 1973, the publication of the Report of the Commission on the Bankruptcy Laws of the United States abruptly reversed this trend of shareholder participation. ${ }^{42}$ As part of a sweeping provision on the subordination of claims, the Commission proposed that investor claims based on federal and state securities legislation, and similar laws, be subordinated in payinent to all general creditor claims. ${ }^{43}$ The Commission's Report contained no explanation for this proposal, but the impetus is likely to have come froin a law review article written during the Commission's tenure by Professors John J. Slain and Homer Kripke.44

40. See e.g., SEC v. Templar, 405 F.2d 126 (10th Cir. 1969) (reorganization of General United Corp.); Protective Comm. v. Anderson, 364 F.2d 936 (5th Cir. 1966) (reorganization of TMT Trailer Ferry, Inc.), rev'd on other grounds, 390 U.S. 414 (1968). In neither case did the court reach the merits of whether successful shareholder fraud claimants could share as general creditors, and in its opinion in Anderson the Supreme Court found it unnecessary to consider the claims. 390 U.S. at 453 . One year earlier the Court had also declined to consider questions regarding the priority of rescission claims by securitylolders-that time, holders of withdrawable capital shares in a savings and loan association-on grounds of prematurity. Tcherepnin v. Knight, 389 U.S. 332, 346 (1967).

41. The cases of Four Seasons Nursing Centers of America and Equity Funding Corp. of America provide examples. Four Seasons went public in the "hot issue" days of May, 1968. Its stock soared from $\$ 11$ per share to the equivalent of $\$ 181.50$ per share in 18 months before collapsing nine months later. In reorganization, the fraud claimants received one-third of the new common stock, valued at approximately 10.5 million dollars. In the Equity Funding reorganization, the largest case of securities fraud in American history, the claimants received $24 \%$ of the new equity, or approximately 20.9 million dollars. In both cases the fraud claimants were principally shareholders. Other rcorganizations in which shareholders were permitted to share in the debtor's assets because of their claims under the securities laws include American Loan \& Fin. Co., No. 508-72-N (E.D. Va.), noted in 39 SEC AN.. ReP. 123 (1973); Farrington Mfg. Co., No. 17-71-A (E.D. Va.), noted in 39 SEC ANN. REP. $123-24$ (1973); and Clute Corp., No. 32895 (D. Colo.), noted in 36 SEC ANN. REP. 187 (1970).

42. For background on the Commission and its Report see supra note 6.

43. Commission Proposal $\$ 4-406(a)(1)$. Section 4-406 also mandated the subordination of claims by officers, directors, and affiliates of the debtor, \$ 4-406(a)(2), and of claims representing fines, penalties, forfeitures, and punitive damages, $\$ 4-406(a)(3)$. Subsection (c) was intended to preserve the courts' "equitable powers" to subordinate other claims and to enforce voluntary subordination agreements. \& 4-406(c).

44. Slain \& Kripke, The Interface Between Securities Regulation and Bankruptcy-Allocating the Risk of Illegal Securities Issuance Between Securityholders and the Issuer's Creditors, 48 N.Y.U. L. REv. 261 (1973). The authors stated that they had submitted a draf of their article to the Commission and "of course hope that our analysis will be reflected in their proposals." Id. at 299. 300 . 
In their article, Slain and Kripke cited precedent for handling shareholder fraud claims in three different ways. First, under the Supreme Court's decision in Oppenheimer, the shareholder could share equally with general creditors.45 Second, the shareholder who purchased his shares directly from the issuer might, at least technically, be preferred over general creditors to the extent that he could trace the specific consideration representing his claim. ${ }^{46}$ Finally, the law could estop the shareholder from asserting a claim, or at least subordinate his claim to those of general creditors.

The final alternative obviously resembles the positions taken by English and American courts throughout the time the subordination issue was actively litigated, ${ }^{47}$ and was the alternative Slam and Kripke thought most appropriate. They argued that the problem involved an allocation of two distinct risks: the risk of business failure and the risk of illegal securities issuance. Both the creditor and the equityholder face the first of these risks, but the equityholder consents to a greater exposure in return for his greater opportunity to participate in the busi-

During the Bankruptcy Commission's deliberations, it was apparently Harold Marsh, Jr., a Los Angeles corporate lawyer and Chairman of the Commission, who first proposed that subordination of securities law claims be included among the Commission's recommendations:

Chairman Marsh said that in any event there was need for some new priority or subordination provisions, and he mentioned stockholders' $\& 10 \mathrm{~b}(5)$ actions which in bankruptcy may permit stockholders to come in on a parity with creditors. He cited the decision of a case down in Kentucky or Tennessee [SEC v. Insurance Investors Trust Co., discussed at supra note 35], where the judge said he had the pistol all cocked to shoot down the stockholders and then said to himself, "Now wait a minute." He did find that the stockholders could come in on a parity with the creditors if the claims were provable. Chairman Marsh said he didn't know whether a \& $10 \mathrm{~b}(5)$ claim is presently provable as it is a tort claim in a sense, but it could also be a sort of contract claim or perhaps a rescission of an original purchase. He felt that to allow classes of claimants for damages for statutory causes of actions to come in and to compete with trade creditors of an insolvent debtor for huge amounts was wrong.

Minutes of the Bankruptcy Commission, Sept. 11-12, 1972, at 12.

The minutes of the Commission ineetings reveal that Chairman Marsh was the primcipal advocate of subordination. Federal district judge Edward Weinfeld initially dissented from the proposal as it applied to the claims of small shareholders, but ultimately agreed to go along with the other Commission members. Id, Jan. 15-16, 1973, at 26-28, Feb. 22-24, 1973, at 37-38. (The minutes of the Bankruptcy Commission are contained among the papers of Congressman $\mathbf{M}$. Caldwell Butler, on file at the Law Library of Washington and Lee University.)

45. 301 U.S. at 215.

46. This preference might occur because, under a general thcory of property transfers voidable by fraud, the transferee holds the property in constructive trust for the transferor, and this trust defeats the rights of the transferee's unsecured creditors. Slain and Kripke found support for this alternative in In re Rhine, 241 F. Supp. 86 (D. Colo. 1965), a case involving the bankruptcy of an unincorporated oil and gas operator. Purchasers of working interests in the enterprise were permitted to reclaim the amounts of their investments from the trustee in bankruptcy. Professor Countryman finds this alternative "a little farfetched" given the unsuccessful attempts of litigants to establish constructive trusts in other areas. Countryman, 'Problem Areas in Chapter $X$ and $X I$ Cases, in Bankruptcy and the Chapter Proceedings 271 (1976).

47. See supra notes 10-24 and accompanying text. 
ness's success. Slain and Kripke saw no reason to reallocate this risk, particularly because the asset cushion provided by the equityholder at least partially motivates the creditor to assuine his share of the risk. Similarly, Slain and Kripke found it "difficult to conceive of any reason for shifting even a sinall portion of the risk of [illegal securities issuance] from the stockholder, since it is to the stockholder, and not to the creditor, that the stock is offered." 48 Consequently, they proposed to subordinate the defrauded shareholder to all subsequent creditors and to any prior creditors who could prove reliance on the shareholder's investment.

Slain and Kripke's position, although different in its exact formulation, was essentially a restatement of the traditional turn-of-the-century arguments for subordination, but it apparently convinced the Bankruptcy Commission. The Commission went even one step further and proposed, in its section 4-406(a)(1), to extend the benefits of the subordination to all of the issuer's general creditors, whether prior or subsequent to any particular securities issue. ${ }^{49}$

Following the Bankruptcy Commission's report in July 1973, legislation embodying the Commission's proposals was introduced in both houses of Congress. ${ }^{50}$ The National Conference of Bankruptcy Judges and the National Bankruptcy Conference both prepared alternatives to

48. Slain \& Kripke, supra note 44 , at 288.

49. See supra note 43. The most important result of the suggestions made by Slain and Kripke and the Bankruptcy Commission was the codification of the subordination doctrine in the Bankruptcy Reform Act of 1978. No doubt their proposals also affected the outcone of proceedings under pre-1978 law. See Kelce v. U.S. Fin. Inc., 648 F.2d 515 (9th Cir. 1980) (absolute priority rule, discussed infra note 81 , coinpelled demial of defrauded preferred shareholder's claims for rescission and reclanation of property exchanged for his shares or for status as a general creditor), cert. denied, 451 U.S. 970 (1981); In re Stirling Homex Corp., 579 F.2d 206 (2d Cir. 1978) (subordination of defrauded shareholders upheld, denying them participation altogether), cert. denied, 439 U.S. 1074 (1979); In re Weis Securities, Inc., 605 F.2d 590 (2d Cir. 1978) (subordinated lenders to a securities broker-dealer estopped, upon the broker-dealer's liquidation, from rescinding the subordination agreements on the grounds of fraud; whether the brokerdealer's customers had relied on the agreeinents irrelevant), cert. denied, 439 U.S. 1128 (1979); In re Cartridge Television, Inc., 535 F.2d 1388 (2d Cir. 1976) (upholding a denial of shareholder fraud claims in bankruptcy as too reinote and contingent, citing Slain \& Kripke with approval).

50. H.R. 10792, 93d Cong., 1st Sess. (1973); S. 2565, 93d Cong., 1st Sess. (1973). The sponsors of these bills, Representatives Edwards and Wiggins and Senators Burdick and Cook, were all meinbers of the Bankruptcy Commission. Their bills were reintroduced in the next Congress. See H.R. 31, 94th Cong., 1st Sess. (1975); S. 236, 94th Cong., 1st Sess. (1975).

For concise narratives of the legislative history of the Bankruptcy Reform Act of 1978, sec H.R. REP. No. 595, 95th Cong., 1st Sess. 2-3 (1977), reprinied in 1978 U.S. CODE CoNo. \& AD. NEWs 5963, 5963-65; S. REP. No. 989, 95th Cong., 2d Sess. 1-2 (1978), reprinted in 1978 U.S. CODE CONG. \& AD. NEws 5787, 5787-88; see also Klee, Legislative History of the New Bankruptcy Law, 28 DePAul L. Rev. 941 (1979). 
the bills based on the Commission's proposals, ${ }^{51}$ but neither proposed any changes in the Commission's provision for subordination of securities law claims. ${ }^{52}$ After extensive hearings on the bankruptcy legislation during the ninety-fourth Congress, however, a subcoinmittee of the House Judiciary Committee drafted a new bill that was eventually introduced in the House of Representatives on January 4, 1977, as H.R. 6.53 Unlike previous alternative proposals, this bill eliminated the mandatory subordination of securities law claims, insider claims and claims based on fines, penalties, forfeitures and punitive damages. ${ }^{54}$ Instead, H.R. 6 provided that a court could subordinate any allowed claim or interest "on equitable grounds" after notice and hearing.s5 The change in the treatınent of securities law claims presumably reflected the advocacy of the SEC, which, as the principal critic of the Bankruptcy Commission's section 4-406(a)(1) in the House and Senate hearings, had argued for subordmation on a case-by-case basis. ${ }^{56}$

During the markup sessions on H.R. 6 held in the spring of 1977, ${ }^{57}$

51. The Bankruptcy judges' proposals were introduced as H.R. 32, 94th Cong., 1st Sess. (1975); S. 235, 94th Cong., Ist Sess. (1975); H.R. 16643, 93d Cong., 2d Sess. (1974); S. 4046, 93d Cong., 2d Sess. (1974). The proposals of the National Bankruptcy Conference, a private organization of law professors, bankruptcy judges, and lawyers are set forth in Bankruptcy Act Revision: Hearings on H.R. 31 and H.R 32 Before the Subcomm on Civil and Constitutional Rights of the House Comm on the Judiciary, 94th Cong., Ist \& 2d Sess. app. pt. 2333 (1976) [hereinafter cited as BANKRUPTCY ACt Revision, 1976 House Hearings]. This appendix also reproduces and compares the language of H.R. 31, 94th Cong., 1st Sess. (1975) (Bankruptcy Commission's proposal) and H.R. 32, 94th Cong., Ist Sess. (1975) (bankruptcy judges' proposal).

52. At its 1974 annual meeting the National Bankruptcy Conference considered the Commission's and the bankruptcy judges' proposals. With respect to section 4-406(a)(1) it concluded that "as a matter of principle, the Conference favors subordination in these cases of claims of both debt and equity securityholders." Summary of Proceedings, National Bankruptcy Conference, 1974 Annual Meeting 3-4 (1974); see also BankRUPTCY ACT Revision, 1976 House Hearings, supro note 51, at 1890 (statement of Harvey R. Miller, William J. Rochelle, Jr. and J. Ronald Trost on behalf of the National Bankruptcy Conference).

53. H.R. 6, 95th Cong., Ist Sess. (1977). See Klee, supro note 50, at 945-46. Subcoininittee Chairman Edwards described this bill as "not a final product. It is a codification of a loose consensus of the subcommittee." 123 CONG. REC. 217 (1977).

54. Both the Bankruptcy judges' and the National Bankruptcy Conference proposals eliminated the inandatory subordination of insider clains but preserved the subordination of the other two classes. BAnKRuptCY ACt Revision, 1976 House Hearings, supra note 51, app. pt. 1, at 142, app. pt. 2, at 355.

55. H.R. 6 § 101, 94th Cong., 1st Sess. (1977) (proposed 11 U.S.C. § 510(b)).

56. SEC Commissioner Loomis, accoinpanied by ineinbers of the SEC staff, appeared at both the House and the Senate hearings to present the SEC's views on the proposed legislation, including its criticism of section 4-406(a)(1). BANkRUPTCY ACT REvISION, 1976 House Hearings, supra note 51, at 2152; The Bankruptcy Reform Aet: Hearings on S. 235 and S. 236 Before the Subcomm. on Improvements in Judicial Machinery of the Senate Comm on the Judiciary, 94th Cong., 1st Sess. pt. II 707 (1975). In addition to the Loomis testimony, the SEC subminted a detailed report on the proposed legislation. See supra note 3.

57. See H.R. Rep. No. 595, 95th Cong., 1st Sess. 3 (1977), reprinted in 1978 U.S. CodE CoNG. \& AD. News 5963, 5964; Klee, supra note 50, at 946. 
however, mandatory subordination of securities law clains was reinstated, with the requirement that the subordination be preceded by notice and hearing. This requirement, apparently carried over from the "equitable grounds" subordination provisions of H.R. 6 as initially drafted, was of doubtful continued effect once the subordmation was made mandatory. With the subordination requirement in substantially this form, the full judiciary committee reported out the bill, renumbered as H.R. 8200,58 in September 1977.59 The committee's report suggested that part of the reason for reinstating inandatory subordination was the concern, raised by Professor Kripke, that case-by-case subordimation-at least under the traditional standards for equitable subordination-would not be available against innocent clainants, such as defrauded shareholders. 60

The House passed H.R. 8200 in February 1978.61 Meanwhile, the

58. The result of the subcommittee's markup was a clean bill which was introduced as H.R. 7330, 95th Cong., 1st Sess. (1977). Section 101 set forth the revised subordination provisions of that bill as proposed 11 U.S.C. $\$ 510$ (a)(2). The subcommittee bill was revised further and a new clean bill, H.R. 8200, 95th Cong., 1st Sess. (1977), was prepared and introduced for consideration by the full House Judiciary Committee on July 11, 1977. See H.R. REP. No. 595, 95th Cong., ist Sess. 3 (1977), reprinted in 1978 U.S. CODE CONG. \& AD NEws 5963, 5964; Klee, supra note 50, at 946-47.

59. H.R. 8200, 95th Cong., 1st Sess. (1977), accompanied by H.R. ReP. No. 595, 95th Cong., ist Sess. (1977), reprinted in 1978 U.S. CODE CONG. \& AD. NEws 5963.

60. As stated in the committee report:

Unfortunately, the SEC's desire to leave the issue to the courts on a case-by-case basis is not as clear cut as it may seem. Professor Kripke has made clear that leaving the issue to the courts to resolve on a case-by-case basis in effect ineans that rescission claims will not be subordinated because the doctrine of equitable subordination is inapplicable as between two innocent third parties.

H.R. REP. No. 595, 95th Cong., lst Sess. 196 (1977), reprinzed in 1978 U.S. CODE CONG. \& AD. NEWS 5963, 6156.

The House subcommittee staff had raised the possibility of continuing to deal with securities law claims through case-by-case subordination-as had been initially provided in H.R. 6notwithstanding Professor Kripke's objections, by providing an appropriate legislative history: "[I]f the Subcommittee intends to permit the court to subordinate on a case-by-case basis then the legislative history accompanying $\S 510($ b) will have to distinguish the concept of subordination on equitable grounds from the classical concept of equitable subordination." Memorandum entitled "Subordination of Security Rescission Claims," prepared for members of the Subcomm. on Civil and Constitutional Rights of the House Comm. on the Judiciary, 95th Cong., Ist Sess., 6 (1977). (This memorandum is contained among the papers of Congressman M. Caldwell Butler, ranking minority member of the House subcommittee, on file at the Law Library of Washington and Lee University. It reveals the inupact of the Bankruptcy Commission and the Slain and Kripke article on the subcommittee's resolution of the subordination issue. The meinorandum outlines the alternative positions regarding subordination and restates the Slain and Kripke article's arguments. Across the top of Congressinan Butler's copy is a handwritten note-presumably that of the congressman himself-which states."(a) HR6 has one view-case by case, (b) Experts have anothermandatory subordination, (c) courts-a third. I go with experts!").

61. Two substantive changes in the provisions subordinating securities law claims occurred between the time they were first reinstated in H.R. 7330 and the passage of H.R. 8200 by the House. First, during subcommittee revision of the bill, the general equitable subordination provi- 
Senate had begun consideration of S. $2266,{ }^{62}$ a bill based on H.R. 8200 , which included section $510(a)(2)$, a mandatory subordination provision identical to that in the House legislation. ${ }^{63}$ In September 1978 the Senate passed its version of the bankruptcy legislation in the form of a substitute amendment to H.R. 8200. In the course of resolving their differences and adopting technical amendments, the requirement of notice and hearing was dropped. ${ }^{64}$ After some last-minute controversy, ${ }^{65}$ the legislation became law on November 6, 1978. With passage of the Bankruptcy Reform Act, Congress remjected the subordination doctrine into American bankruptcy law with a vitahty that it had not enjoyed since the earhest American decisions, if then. ${ }^{66}$

sion-proposed 11 U.S.C. \&510(b)-was amended to make it clear that it applied "[n]otwithstanding subsection (a)." H.R. 8200, 95th Cong., 1st Sess. (1977) (proposed 11 U.S.C. $8510(b))$. Thus, claims of participants in the fraud could be subordinated to the defrauded securityholders. Second, the full committee modified the ranking of the securities law claims by subordinating them to "all claims and interests that are senior or equal to the claim or interest represented by such security." H.R. 8200, 95th Cong., 1st Sess. (1977) (proposed 11 U.S.C. 8 S10(a)(2)) (emphasis added). The subcommittee bill had given only senior claims and interests the benefit of subordination.

62. S. 2266, 95th Cong., 1st Sess. (1977).

63. During hearings on S. 2266, SEC Commissioner Loomis again testified and submitted a statement by the SEC which reiterated its objection to the subordination scheme in section $510(a)(2)$. As before, the SEC argued to the Senate for case-by-case subordination "in accordance with the equities of the case." Bankruptcy Reform Act of 1978: Hearings on S. 2266 and H.R. 8200 Before the Subcomm on Improvements in Judicial Machinery of the Senate Comm. on the Judiciary, 95th Cong., 1st Sess. 620, 628 (1977). Nevertheless, the Senate Judiciary Committee reported out the bill with mandatory subordination unchanged. See S. 2266, 95th Cong., 2d Sess. (1978), accompanied by S. REP. No. 989, 95th Cong., 2d Sess. (1978), reprinted in 1978 U.S. CODE CoNG. \& AD. News 5787.

64. See 124 ConG. REC. 32,361 (1978) (setting forth the text of section $510(b)$ as included in the compromise amendment agreed to by the House and Senate floor managers of the legislation). Apparently the fioor managers viewed this change simply as a technical and clerical amendment and gave no explanation for it. See id. at 32,398; id at 33,998 (floor statements of Rep. Edwards and Sen. DeConcini, respectively, explaming the House-Senate compromise).

65. This principally related to the status of the bankruptcy courts. See Klee, supra note 50, at 954-57.

66. In the ninety-sixth Congress, as part of a series of technical amendments, proposals to make changes in the language and narrow changes in the substance of section 510(b) were introduced in both houses. The amendinent to section 510(b) adopted by the Senate Judiciary Committee appears in S. 658 \& 128, 96th Cong., 1st Sess. (1979), accompanied by S. REP. No. 305, 96th Cong., Ist Sess. (1979). The amendment adopted by the House Judiciary Committee appears in S. 6588 36, 96th Cong., $2 d$ Sess. (1980), accompanied by H. R. REP. No. 1195, 96th Cong, $2 d$ Sess. (1980).

Both versions modify the "senior or equal" provision in Section S10(b), see supra note 61, and thereby alter the precise ranking of securities law claims within the overall hierarchy of claims. Both versions, however, subordinate securities law claims to the claims of all scnior securities. Thus, shareholder securities law claims would, in all cases, be subordinated to contract creditors. Both houses ultimately passed bills eunbodying the House version of this change, 126 CONG. REC. S15,160, 15,163 (daily ed. Dec. 1, 1980); id. at H11,725, 11,729 (daily ed. Dec. 3, 1980). Agreement on various other provisions of the technical amendments package, principally those regarding 


\section{Traditional Justifications for: the Subordination DOCTRINE}

The judicial development of the subordination doctrine, the recent commentary of Slain and Kripke, and the legislative history of section 510(b) suggest four distinct arguments for subordinating the defrauded shareholder. First, corporate creditors rely on the equity cushion provided by the shareholder's capital; therefore, the law should not allow the shareholder to invoke remedies that would contravene creditors' legitimate expectations. Second, the shareholder accepts a position junior to general creditors, in part, as a quid pro quo for his right to sole participation in the corporate estate after the creditors' fixed claims have been satisfied. Allowing him to participate if the corporation succeeds but to renounce shareholder status and claim as a general creditor if the corporation fails gives him the best of both worlds and is unfair to the other creditors. Third, shareholder fraud reinedies against the issuer have developed with the implicit expectation that the economic burden of the remedy will fall on the issuer, who was involved in the wrongdoing and may have benefited by it. If the issuer's insolvency shifts the burden to the pockets of innocent creditors, many of the policies underlying the remedies would not apply. Fourtl, traditional principles of estoppel and laches should bar the shareholder from asserting a reinedy ${ }^{67}$ After briefly reviewing some general principles of bankruptcy law that support treating the defrauded shareholder as a general creditor, this part considers the first three subordination rationales in depth. 68

\section{A. Some General Principles in Support of Parity.}

Hornbook bankruptcy law dictates that, with limited exceptions, ${ }^{69}$

retireinent of bankruptcy judges, was not reached, so none of the technical amendments, including the subordination change, became law.

Bankruptcy amendments legislation was introduced in both houses of the ninety-seventh Congress. The Senate passed a coinprehensive set of amendments, including an amendment to section 51O(b) similar to that passed by the prior Congress, see S. 863 \& 36, accompanied by $S$. REP. No. 150, 97th Cong., 1st Sess. (1981) (passed July 17, 1981); 127 CONO. REC. S7907 (daily ed. July 17, 1981). The leadership of the subcommittee with responsibility for bankruptcy legislation in the House, however, did not include any substantive changes to section 510(b) in the technical amendments bill introduced in 1981. See H.R. 3705, 97th Cong., 1st Sess. (1981).

67. This overlaps to soine extent with the first and second rationales.

68. The concepts of estoppel and laches will be discussed in connection with the first and second rationales.

69. The principal exceptions are: (1) the statutory priority system set forth in Bankruptcy Code $\$ 507,11$ U.S.C. 8507 (Supp. V 1981); (2) the equitable subordination doctrine discussed in the ensning text; and (3) the subordmation of claims representing fines, penalties, and punitive damages pursuant to Bankruptcy Code \& 726(a)(4), 11 U.S.C. \& 726(a)(4) (Supp. V 1981). 
claims of all general creditors stand on the same footing. ${ }^{70}$ In general, the law does not discriminate on the basis of the nature of the claim, the nature of the claimant, or the nature of the claimant's relationship to the debtor. Instead, substantive law outside the bankruptcy process defines the elements necessary to give one person a claim against another and the bankruptcy system defers to that substantive law by treating all clains equally. A widow who loaned her last $\$ 5,000$ to the debtor shares in pari passu with the claim of a wealthy actress whom the debtor owes $\$ 750,000$ for doing nothing because it elected not to produce the inotion picture in which it had signed her to star. ${ }^{71}$ Further, a \$10,000 contract claim against the debtor, whether for money loaned, goods delivered, or service performed, generally stands on a par with a $\$ 10,000$ tort claim against the debtor resulting, for example, from the wrongful conduct of its employees. ${ }^{72}$ The equitable subordination doctrine provides the only general opportunity for a court to look behind a claim and discriminate against it on the basis of its underlying facts. A review of the cases applying this doctrine indicates its limited scope: ${ }^{73}$ the claims involved are usually asserted by a controlling shareholder or other insider of the debtor, and courts invoking the doctrine usually ${ }^{74}$ premise it on some element of fraud, wrongdoing, or mismanagement by those claimants-often unrelated to the claims themselves. ${ }^{75}$ Thus the doctrine does not provide blanket authorization for courts to discriminate against otherwise valid claims on the basis of

70. J. MCLAChLAN, HandbooK ON the LAW OF BANKRuptCY $\$ 256$ (1956).

71. The facts for the latter example are derived from Parker v. Twentieth Century-Fox Film Corp., 3 Cal. 3d 176, 474 P.2d 689, 89 Cal. Rpts. 737 (1970).

72. Under the Bankruptcy Act, some classes of tort claims were not provable in bankruptcy until reduced to judgment. This had no bearing on the parity of tort and contract claims, however, a provable tort claim stood on a par with a provable contract claim. The Bankruptcy Code essentially eliminates the concept of provability. See 11 U.S.C. \& 101(4) (Supp. V 1981).

73. See Herzog \& Zweibel, The Equitable Subordination of Claims in Bankruptcy, 15 VAND. L. REV. 83 (1961).

74. The exceptions involve "inadequate capitalization" cases, in which the controlling shareholders of a corporation structure most of their investment in the form of loans to the corporation rather than purchasing equity with the result that the corporation has an unusually high debt-toequity ratio. In bankruptcy, outside creditors object to the insiders' claims on the grounds that they actually represent a proprietary interest in the business and should be junior to other creditors. These situations should more properly be viewed as problems of disallowance rather than subordination. See Herzog \& Zweibel, supra note 73 , at $93-94$. The cases do not clearly reveal whether inadequate capitalization by itself warrants subordination. See Clark, The Duties of the Corporate Debtor 10 Its Creditors, 90 HARv. L. REv. 505, 534-36 (1977).

75. One recent article characterizes the equitable subordination doctrine as a functional substitute for conventional fraudulent conveyance law. Equitable subordination enjoys an advantage: it provides the trustee in bankruptcy with certain administrative and procedural conveniences and an expanded apphication not available under the latter doctrine. Clark, supra note 74 , at $517-36$. 
an equitable assessment of their worthiness; indeed, the cases applying the doctrine supply no support for subordinating the claim of a passive investor that arises solely from the wrongdoing of another. ${ }^{76}$

Even if bankruptcy law permitted discrimination between all classes of claims based on general notions of their equitable worthiness, it is far from clear that shareholder fraud claims should be or would be among those classes disfavored. An investor who pays an issuer $\$ 50$ for a share of stock worth only $\$ 20$ because the issuer's management has misrepresented its financial condition in order to drive up the stock price suffers a direct and immediate loss of value. In economic terins this value loss is no different from that incurred if $\$ 30$ were taken froin him by force. Moreover, unlike many tort claims the investor's $\$ 30$ loss creates a matching $\$ 30$ gain to the debtor. This increases the amount of the debtor's estate available to creditors by $\$ 30$. Not only is the inves- . tor economically injured but the debtor is unjustly enriched.

Even the principal proponents of subordination concede that, if anything, the general policy of the law is to favor the victim of fraud or mistake over the general contract creditor, ${ }^{77}$ presumably because the forner had no valid opportunity to consent to the true risks involved in dealing with debtor ${ }^{78}$ Consequently, in seeking to compel subordination of securities law claims, the proponents of section $510(\mathrm{~b})$ must conclude that circuinstances peculiar to the sharelolder-creditor relationship warrant a deviation from these general principles. The following sections consider the validity of this conclusion.

76. One of the reasons given for making specific provision for shareholder fraud claims under section $510($ b) was that traditional principles of equitable subordination were not applicable "as between two innocent third parties." See supra note 60 . These traditional principles of equitable subordination have been codified in section 510(c) of the Bankruptcy Code. The Senate report on this provision stated: "Any subordination ordered under this provision must be based on principles of equitable subordination. These principles are defined by case law, and have generally indicated that a claim nay normally be subordinated only if its holder is guilty of misconduct." S. REP. No. 989, 95th Cong., 2d Sess. 74 (1978), reprinted in 1978 U.S. CODE CONG. \& AD. NEWS 5787, 5860.

77. Slain \& Kripke, supra note 44 , at $284-85$. The equitable mechanism for preferring the fraud or mistake victim is to impose a constructive trust on the property transferred by the victim to the debtor. See Restatement of Restitution $\$ \$ 166,160$ comment $f, 173$ comment $j$ (1937). The constructive trust will survive in bankruptcy to permit the fraud or mistake victim to reclaim the property froin the bankruptcy estate. $4 \mathrm{~L}$. King, Collier on BanKruptcy I 541.13 (15th ed. 1982); U.S. Life Title Ins. Co. v. Lester (In re Fielderest Homes, Inc.), 18 Bankr. 678 (Bankr. N.D. III. 1982); Travelers Ins. Co. v. Angus (In re Angus), 9 Bankr. 769 (Bankr. Ore. 1981).

78. Of course, the same facts that cause the sharelolder's loss may cause many general contract creditors to be defrauded as well. Thus, in most cases no favoritism of one group over the other would be warranted. Cf. infra text accompanying note 187 (diseussing how subordination doctrine favors defrauded creditors over defrauded shareholders). 


\section{B. Reliance by Corporate Creditors.}

As Part I of this article demonstrates, the rationale imvoked most consistently and forcefully to support subordination has been that subordination is necessary to protect the creditor's legitimate expectation that his claim will be senior to the "investment" or "contract" claims of shareholders. ${ }^{79}$ American courts, relying on this rationale, have distinguished between relying and nonrelying creditors, extending the benefits of subordination only to the former. ${ }^{80}$ Professors Slain and Kripke also advocated this distinction, and the reliance rationale appears to form the core of their position as well..$^{81}$

1. The Two Dimensions of Creditor Reliance: Priority and Cushioning. In its purest terms, a corporate creditor's reliance on the subordination of equityholders involves two aspects: "priority" and "cushioning." Priority means simply that debt is senior to equity. If the corporation is liquidated, in bankruptcy or otherwise, debts-must be paid in full before any remaining assets are distributed to equityholders; if the corporation is reorganized, the "absolute priority" rule developed under Chapter X of the former Bankruptcy Act assures the creditor a comparable protection of his expectation of seniority. ${ }^{82}$

This structuring of the creditor-shareholder relationship leads to a second aspect of rehance referred to as the cushion factor. The cushion may be viewed as the portion of the balance-sheet assets attributable to the shareholders' paid-in capital or to earnings reinvested in the business that, at least in theory, enable the business to absorb losses over time without compromising its capacity to pay creditor claims in full. ${ }^{83}$

79. Throughout this article the terms "contract claims" and "investment claims" of shareholders refer to shareholders residual claims to the assets of the corporation under traditional corporate law, as opposed to any securities law claims they may have.

80. See supra notes 18-24 and accompanying text.

81. See supra notes $47-49$ and accompanying text.

82. The absolute priority rule required that each senior class of claimants against the debtor receive cash or securities equal to the full value of its claims before any junior class could participate. Thus, if the reorganized debtor had a going concern value of $\$ 10$ million and creditor claims totalled $\$ 12$ million, creditors would be entitled to receive the full interest in the debtor. Any creditor could attack a plan that provided equityholders any participation, no matter how small. The rule developed as an interpretation of the "fair and equitable" requirement for judicial approval and confirmation of the reorganization plan. See Consolidated Rock Prods. Co.v. DuBois, 312 U.S. 510 (1941); Case v. Los Angeles Luniber Prods. Co., 308 U.S. 106 (1939); Bankruptcy Act $88174,221(2), 11$ U.S.C. $\$ 8574,621(2)$ (1976). The new Bankruptcy Code has adopted a hybrid form of the absolute priority rule for application 'to reorganizations under Chapter 11. See 11 U.S.C. \& 1129 (b) (Supp. V 1981).

83. The statement in the text, phrased in terms of balance-sheet assets, describes the traditional characterization of the equity cushion. Modern financial theory holds, however, that the value of an ongoing business enterprise is determined not by its balance sheet assets but by the discounted present value of its future cash flows. This change in orientation does not alter the 
The cushion also serves to assure creditors that the shareholders, who elect management, have a substantial risk exposure in the business and will not gamble with the creditors' money.

The existence and size of the corporation's equity cushion no doubt often plays a major role in a prospective lender's decision to grant credit. ${ }^{84}$ Corporate law protects the creditor's rehiance on this cushion by limiting the amount of assets the corporation may distribute to its shareholders and by permitting creditors to impose additional distribution limitations by contract. Not surprisingly, some of the commentators on the bankruptcy subordination doctrine, including Slain and Kripke, phrase their reliance rationale largely in terns of the right of creditors to rely on the equity cushion. ${ }^{85}$ In bankruptcy, however, the cushion aspect of the debt-equity relation means less than it does in the setting of a loan decision. The fact of the corporation's bankruptcy often suggests that the cushion, whatever its past importance, has been exhausted and is no longer of much value to creditors. ${ }^{86}$ Instead, as a corporation approaches insolvency, creditors become concerned with the amounts and kinds of competing claims for the debtor's assets-in other words, the priority aspect of rehance.

Furthermore, if proponents of subordinating securities law claims really wish to protect the cushion, the subordmation doctrine, triggered only in bankruptcy, is a poor solution. Prior to bankruptcy, securities law claims erode the cushion, as does any other forn of business loss.

cushioning aspect of equity. The equity cushion becomes the excess of the present value of the term's future cash flows over the present value of the interest and primcipal payments due creditors.

84. The extent to which a prospective creditor will inquire into the corporation's financial condition (both present and prospective) as a basis for deciding to extend credit varies with the amount of the credit, the duration of the credit, and the nature of the creditor. Corporate creditors fall into three groups: (1) trade creditors who supply the corporation with goods or services; (2) banks, insurance companies, and other institutional lenders; and (3) public investors who purchase the corporation's debt securities. Because of the costs involved, trade creditors nay not find it worthwhile to make an individual credit assessment, although they might rely on information provided by companies like Dun \& Bradstreet. The trade creditor may, therefore, rely more on past experience with the corporation and its general reputation for paying its debts than on its balance-sheet financial condition. See infra note 110 (authorities cited). Institutional lenders, on the other hand, will typically make a detailed review of the corporate financial condition as a part of the loan negotiation process. Public investors in effect delegate this review process to others, specifically the investment bankers that underwrite the debt securities and the rating agencies (Moody's and Standard \& Poor's) that assign a rating to them.

85. See, eg., Jezarian v. Raichle (In re Stirling Hoinex Corp.), 579 F.2d 206, 214 (2d Cir. 1978), cert. denied, 439 U.S. 1074 (1979); Slain \& Kripke, supra note 44, at 286-89.

86. This will not necessarily be the case in all bankruptcies. In some, the corporation may have a positive equity cushion as ineasured by its net worth, and nonetheless be motivated to declare bankruptcy because of liquidity-based difficulties in ineeting its debts as they become due. The potential existence of these exceptions does not, however, alter the analysis that follows. 
The subordination doctrine only assures a bank making a corporate loan that if the company becomes bankrupt, the bank can recover the full amount of its loan before the shareholders may participate in the corporate asset pool on the basis of their securities law claims or otherwise. But this is all the doctrine assures. If the shareholders discover their claims and reduce them to judgment prior to bankruptcy, they are entitled to full payment froin the assets of the company. The bank can then invoke the subordination doctrine only if it can force the corporation into an involuntary bankruptcy. ${ }^{87}$ If the corporation is otherwise healthy financially the bank may be extremely reluctant to take this step. ${ }^{88}$ Thus, because assets representing securities law claims may be withdrawn from the corporation, thereby reducing its equity cushion, at any time short of bankruptcy, the subordination doctrine is not a logical adjunct to the creditor's legally protected rehiance interest with respect to the cushion aspect of the debt-equity relation. ${ }^{89}$

87. Under the Bankruptcy Code, any three creditors with total claims of $\$ 5,000$ or more may commence an involuntary case. Bankruptcy Code \& 303(b), 11 U.S.C. \& 303(b) (Supp. V 1981). The court must order involuntary relief unless the debtor controverts the petition; if the debtor does so, the court will dismiss the petition unless it finds, after a trial, that:

(1) the debtor is generally not paying such debtor's debts as such debts become due; or

(2) within 120 days before the date of the filing of the petition, a custodian, other than a trustee, receiver, or agent appointed or authorized to take charge of less than substantially all of the property of the debtor for the purpose of enforcing a lien against such property, was appointed or took possession.

Id $\& 303(\mathrm{~h})$. Thus, in order to force a corporation into bankruptcy, a creditor must persuade two other creditors to join it in a bankruptcy petition and inust be prepared to prove that the corporation is not meeting its debts as they become due.

88. One commentator, discussing the disadvantages of contractual subordination arrangements triggered only by bankruptcy lias noted that "[f]roun the practical point of view, probably one of the least successful ways for a creditor to collect money from a debtor is to put the debtor into bankruptcy." Calligar, Subordination Agreements, 70 YALE L.J. 376, 380 (1961).

89. There is a similar weakness in the estoppel argument for preventing sliarelolders from asserting securities law claims. This argument has been made and sometimes accepted in a few cases involving claims based on failure to comply with state blue sky laws. See Slain \& Kripke, supra note 44, at 281-82 (quoting from In re Racine Auto Tire Co., 290 F. 939 (7th Cir. 1923)); see also cases discussed at 3 L. Loss, Securities Regulation 1679-81 (2d ed. 1961). But conventional estoppel requires some representation or concealment by the party to be estopped on which the party asserting the estoppel relies to his detriment. See generally 3 J. POMERoY, TrEatisE ON EQUITY JURISPRUDENCE $\$ 805$ (5th ed. 1941). Thus an estoppel of shareholders' securities law remedies would logically depend on some representation by the shareholders that they would forego such remedies in favor of the corporate creditors. In the example in the text, until the shareholders detect the violations giving rise to their claims, no basis exists for inferring such a representation or for creditor relianee on it. The creditors continue to risk that the shareholders will learn of their claims and recover a judgment froin the corporation. Only after the shareholders acquire knowledge or notice of the existence of grounds for recovery and fail to act can such a representation be claimed. See Royal Air Properties, Inc. v. Smith, 333 F.2d 568, 570 (9th Cir. 1964); Regan v. Albin, 219 Cal. 357, 359-60, 26 P.2d 475, 476 (1933); R. Stevens, HandBooK of THe Law of Private Corporations 890 , at 411 (2d ed. 1949) (specifically discussing the question of rescission after insolvency); Note, Applicability of Waiver, Essoppel, and Laches Defenses to Private Suit Under the Securities Act and S.E.C. Rule 106-5: Deterrrence and Equity in Balance, 73 
The subordination doctrine's relation to the priority aspect of the debt-equity relationship permits, however, a stronger argument that subordination is consistent with creditor expectations. Assuining that a bank does place significant weight on a corporation's financial condition in deciding to make a loan, the bank will assess not only the corporation's immediate financial position but also the potential changes in that position over the course of the loan. For exainple, the bank will evaluate prospective cash flow and the coinpeting claims that may arise against it. If the corporation goes bankrupt, the bank unay properly assert a priority over the contract claims of the corporation's shareholders; therefore, the bank would not treat these as competing claims when Inaking its initial credit assessment.

What about any securities law claims by these shareholders? The bank probably could not project the creation and assertion of this whole new class of coinpeting claims. If this represents the more accurate and realistic view of why parity for securities law claims interferes with creditors" "reliance" interests, the problein really involves a larger question of the business risk resnlting froin any corporate borrower's exposure to large-scale class action judgenents. Is there any reason for immunizing a creditor froin this risk when it arises froin a securities law clain, if the creditor must accept the risk that a coinparable clainr inay arise froin an antitrust or products safety class action?

Suppose that Futurific Enterprises has recently raised $\$ 30$ million through a public offering of its stock underwritten by Buckett, Shoppe $\&$ Co., an investinent banking firm. The prospectus for the offering contained a materially inisleadimg statement and when the truth is discovered the price of Futurific stock falls froin $\$ 30$ to $\$ 5$. Both Futurific and Buckett, Shoppe then file for bankruptcy. Members of Futurific's inanagement and several Buckett, Shoppe principals knew that the stateinent was false at the time of the offering. One group of imvestors who purchased shares in the offering brings a class action for $\$ 12.5$ imillion against Futurific under section 11 of the Securities Act of $1933 ; 90$ another group brings a $\$ 12.5$ million class action against Buckett, Shoppe under the saine section. Under the Bankruptcy Code, the court inust subordinate the section 11 claims asserted against Futurific

YALE L.J. 1477, 1486-87 (1964) (by implication). Consequently, actions by the shareholders prior to this point, such as voting their shares, receiving dividends, or even participating in manageunent, are meaningless for purposes of estoppel theory because they communicate nothing about the shareholders' likely reaction when they discover the violations. Also, only those who become creditors after this discovery-with actual or presumed knowledge of the shareliolders' inaction after discovering the violation-can legitimately claim the reliance necessary to assert an estoppel.

90. 15 U.S.C. \$77k (1976). 
to the claims of Futurific's general creditors, ${ }^{91}$ but it will not subordinate the same claims against Buckett, Shoppe unless Buckett, Shoppe is an "affiliate" of Futurific.92 If Buckett, Shoppe is not an affiliate, the investor claimants will share equally with Buckett, Shoppe's general creditors. ${ }^{93}$ But is there any a priori basis for saying that the probable expectations of Futurific's creditors concerning the risk of these claims is any different from those of Buckett, Shoppe's creditors?

Proponents of the reliance rationale have failed to give a truly satisfactory answer to this apparently unreasonable discrimination between securities law claims against bankrupt issuers and securities law claims against bankrupt nornssuers. They also fail to explain the distinction between securities claims and antitrust or products liability cases. To explaim both distinctions, they essentially argue (1) that debtholders have a priority over the contract claims of equityholders, (2) that debtholders presumably rely on this priority in deciding to extend credit and in pricing that credit, and (3) that because participation by equityholders' securities law claims would produce similar economic consequences to participation by equityholders' contract claims, ${ }^{94}$ debtholders inust have priority over the securities law. claims

91. Bankruptcy Code § 510(b), 11 U.S.C. § 510(b) (Supp. V 1981).

92. By its terms, section 510 (b) subordinates securities law claims based upon the purchase or sale of a security "of the debtor or of an affiliate." The term "affiliate" is defined to include any:

(A) entity that directly or indirectly owns, controls, or holds with power to vote, 20 percent or more of the outstanding voting securities of the debtor, other than an entity that holds such securities-

(i) in a fiduciary or agency capacity without sole discretionary power to vote such securities; or

(ii) solely to secure a debh, if such entity has not in fact exercised such power to vote; (B) corporation 20 percent or more of whose outstanding voting securities are directly or indirectly owned, controlled, or held with power to vote, by the debtor, or by an entity that directly or indirectly owns, controls, or holds with power to vote, 20 percent or more of the outstanding voting securities of the debtor, other than an entity that holds such securities-

(i) in a fiduciary or agency capacity without sole discretionary power to vote such securities; or

(ii) solely to secure a debt, if such entity has not in fact exercised such power to vote; (C) person whose business is operated under a lease or operating agreeinent by a debtor, or person substantially all of whose property is operated under an operating agreement with the debtor, or (D) entity that operates the business or all or substantially all of the property of the debtor under a lease or operating agreenent. . . .

Bankruptcy Code $\$ 101(2), 11$ U.S.C. \& 101(2) (Supp. V 1981).

93. If a substantial portion of Buckett, Shoppe's business involves operating as a brokerdealer at the retail level, the claims of perhaps its largest class of general creditors-its brokerage customers-will, under either the Securities Investor Protection Act of 1970 or the Bankruptcy Code, have a priority over the section 11 claims. See Securities Investor Protection Act of 1970 \$ 6(c)(2), 15 U.S.C. \& 78ff(c)(2) (1976); Bankruptcy Code $\$ \$ 751,752,11$ U.S.C. $\$ 8751,752$ (Supp. V 1981). This result has no bearing on the analysis in the text, however.

94. The consequences of participation by equityholder securities law claims and by equityholder contract claims are similar but not identical. First, some equityholders will have no basis 
as well. 95

This reasoning involves significant bootstrapping. Few would seriously dispute that the claims of corporations' creditors should have priority over the contract claims of their shareholders. Even though the resulting rehance by creditors on this priority forms an important basis for enforcing it, the principal basis for enforcement is the implicit contract itself. ${ }^{96}$ A deal is, after all, a deal.

More to the point, the terns of any underlying deal between creditors and shareholders are, in the absence of express contractual provisions, whatever terms the law chooses to write. If Congress had provided in the Bankruptcy Code that securities law claims would participate on a par with general creditors, creditors-at least those who extended credit after the adoption of the Code-could not argue that parity violated their reliance interests. The real issue underlying the reliance rationale is, therefore, whether it is advisable from the standpoint of sound corporate law policy to provide creditors a limited immunity97 from the risk of securities law claims.

2. Possible Justifications Underlying the Reliance Rationale: Implicit Agreements and Costs of Capital. Two alternative views of the rehance rationale could provide the necessary justification for protecting creditors from this risk. The first is that subordination represents the existing implicit agrcennent between creditors and shareholders for

for recovery under the securities laws-they may have purchased their shares before the fraudu. lent activity commenced or after its disclosure. Second, some securities law claimants may no longer be equityholders, but former equityholders who have sold their shares. Third, the amount of the eqnityholders' participation under contract or securities law claims will differ both in individual cases and in the aggregate because the amount recoverable under the latter claims usually differs from the offering or trading price of the shares.

95. Some recent authorities frame this argument in terms of the absolute priority rule described supra at note 82 . That rule, so their argument runs, reflects the claimants' underlying expectations, which would be violated if securities law claims are given parity. Thus, they conclude, the absolute priority rule compels subordination. Kelce v. U.S. Fin., Inc., 648 F.2d 515, 519. 21 (9th Cir. 1980), cert. denied, 451 U.S. 970 (1981); see also Huff, The Defrauded Investor in Chapter X Reorganizations: Absolute Priority v. Rule 10b-5, 50 AM. BANkR. L.J. 197 (1976); Slain \& Kripke, supra note 44, at 262-63, 286-87 (first suggestion of this argument). This adds nothing to the argument in the text. The absolute priority rule concerns step (1), the debtholders' priority over the contract claims of shareholders. It adds no fresh support for the key point of the argument, step (3), regarding why this priority should also apply to securities law claims.

96. For example, courts have enforced contractual subordination arrangements even when proof of reliance by the senior classes is lacking. See In re Credit Indus. Corp., 366 F.2d 402, 407. 10 (2d Cir. 1966); see also Evereth, Subordinated Debt-Nature and Enforcement, 20 Bus. LAw. 953, 964-67 (1965) (discussing In re Aktiebolaget Kreuger \& Toll, 96 F.2d 768 (2d Cir. 1938), and In re Associated Gas \& Elec. Co., 53 F. Supp. 107 (S.D.N.Y. 1943), affd sub nom. Elias v. Clarke, 143 F.2d 640 (2d Cir.), cert. denied, 323 U.S. 778 (1944)).

97. This immunity is "limited" because it exists only if the corporation enters bankruptcy. See supra text accompanying notes $87-89$ \& infra note 119 . 
allocating the risk of securities law violations. If this is the case, Congress has no reason to upset this agreement by adopting a contrary rule of parity-particularly because many parties might act without specific knowledge of the statutory rule. There is hittle evidence, however, to suggest that creditors' and shareholders' expectations are well formed on this point, much less that their expectations coincide. A survey of creditors and shareholders concerning the rule in the context of a specific fact situation, such as the Futurific hypothetical, might well find that few knew of any rule and that among those who had views on this point, creditors favored a rule of subordination and shareholders favored a rule of parity.

The second formulation of reliance policy is more result-oriented: a rule of parity, by shifting a portion of the cost of securities law violations to creditors, would deter or increase the cost of beneficial lending and serve as a disincentive to corporate creditors generally. This forinulation acknowledges that no clear implicit agreement between creditors and shareholders concerning the participation of securities law claims exists, and asks instead what effect each rule-subordination and priority-would have on the credit and investment decisions inade by each party.

This formulation requires soine puzzling assumptions about the inadequacy of financial market forces. If prospective lenders regarded a rule of parity as materially reducing the expected payoff of a contemplated loan, their easy response would be to demand compensation for this greater risk in the form of a higher interest rate. Admittedly, this would increase the cost of debt financing, but at the same time by providing shareholders with a greater recovery in the event of securities law violations it would presumably reduce the cost of equity financing. Thus it is not clear that subordination of securities law claims would affect a corporation's total costs of capital: increases or reductions in the cost of equity financing might offset reductions or increases in debt costs. ${ }^{98}$

98. Clearly, the question of a distinction between subordination and parity rules as they affect the relative costs of debt and equity financing is a complex one, involving, among other considerations, the elasticity of the supply of business credit. $C$. Meckling, Financial Markets, Default, and Bankruptcy: The Role of the State, 41 LAw \& CoNTEMP. ProBs., Autumn 1977, at 13, 19-24; Weston, Some Economic Fandamentals for an Analysis of Bankruptcy, id at 47, 48-51 (discussing the general question of who bears the increased costs of lending resulting from changes in the bankruptcy law). A definitive answer to this question awaits an empirical study. The important point for present purposes, though, is that no a priori reason exists for believing that any increased risk to lenders-posed by the parity rule and passed on to corporate borrowers in the form of higher interest rates-would not be offset by a willingness on the part of the shareholders to accept the resulting decreased return as fair compensation for the greater protection they receive against security fraud losses. 
Furtherinore, the assumption that the distinction between the parity and subordination rules would have a material impact on prospective creditors is itself doubtful. The issue is not the impact of the rule on creditors at the time of bankruptcy, but its impact on creditor expectations at the time their lending decisions are made.

The impact of a subordination rule is different today from what it would have been during the last three decades of the nineteenth century, when American courts largely developed the rehance rationale for favoring contract creditors over defrauded shareholders. In the late nineteenth century, equity commitinents largely took the forn of subscriptions, ${ }^{99}$ shareholders were few and often insiders, ${ }^{100}$ and nominal capital was regarded as representing the principal, perhaps sole, basis for a corporation's credit. ${ }^{101}$ The courts of this period operated without benefit of modern financial or accounting theory. ${ }^{102}$ Understandably

\footnotetext{
99. As stated by one commentator:

It is a common saying and a well-recognized fact that the subscribers to certain corporate enterprises, especially railroads, rarely realize a profit from their investment, but, on the contrary, lose the whole amount of the subscription which they have inade. These subscriptions are generally not called in until after corporate insolvency has occurred. Then the reluctance of the subscriber to pay a subscription from which there is no hope of a return leads him to search out and build up all possible defenses to defeat any action for the collection of the amount due froin hin.
}

1 W. Cook, Treatise on the law of Corporations having a Capital Stock $§ 166$, at 314 (4th ed. 1898).

100. Throughout most of this period, businesses, with the exceptions of the railroads, cotton textile mills, and some large financial institutions and mining enterprises, were still closely held and their securities were just beginning to receive the attention of the investment banking community. See V. Carosso, Investment Banking in America 29-50 (1970); Navin \& Sears, The Rise of a Market for Industrial Securities, 29 BUs. Hist. REv. 105, 105-16 (1955); R. Foulke, PRACTICal Financlal Statement Analysis 25 (6th ed. 1968).

101. Justice Mitchell's opinion in the Hospes case provides the classic statement of this view:

The capital of a corporation is the basis of its credit. It is a substitute for the individual liability of those who own its stock. People deal with it and give it credit on the faith of it. They have a right to assume that it has paid-in capital to the amount which it represents itself as having....

... Inasmuch as the capital of a corporation is the basis of its credit, its financial standing and reputation in the commumity has its source in, and is founded upon, the amount of its professed and supposed capital, and everyone who deals with it does so upon the faith of that standing and reputation, although, as a matter of fact, he inay have no personal knowledge of the amount of its professed capital . . . .

Hospes v. Northwestern Mfg. \& Car Co., 48 Minn. 174, 197-98, 50 N.W. 1117, 1121 (1892). For examples of similar language from other court opimions of the period see D. DODD, STOCK WATERING 14-17 (1930); see also I W. CoOK, supro note 99, § 199, at 358, which after advancing this position, concludes: "The public has a right to assume that the capital stock has been or will be fully paid up, if it be necessary in order to ineet corporate liabilities. Accordingly, the American courts go very far to protect corporate creditors . . .."

102. See the comments of Bayless Manning on the lack of a cohesive theory of corporate finance by the courts of this period. B. MANnING, supra note 18, at 16, 17-39 passim.

On the early development of the accounting profession in this country see R. FouLKE, supra note 100, at 21-23; Hawkins, The Development of Modern Financial Reporting Practices Among American Manufacturing Corporations, 37 Bus. Hist. REv. 135, 153-55 (1963). 
they sought to ensure that nominal capital in the form of subscription habilities provided a true source of assets for the creditor-outsiders if the venture failed. ${ }^{103}$ Thus, nineteenth century courts viewed fraud as simply another defense a subscriber could not use to avoid hability for his portion of the full value of the equity fund.

Consider, for example, the situation behind the first federal court cases to consider the fate of the defrauded shareholder of an insolvent corporation. ${ }^{104}$ In the 1870 s, an agent for a newly reorganized fire and casualty insurance company, Great Western, called on prospective investors and offered them the opportunity to purchase shares of the company's $\$ 100$ par value common stock for a down payment of $\$ 20$ per share. The agent said that, although the investor was technically liable for the balance, no further assessment would be made. One year later Great Western, having made the unfortunate business decision to write fire insurance in Chicago in the early 1870 s, incurred claims well in excess of its assets and passed into receivership. When the receiver sought to collect the balance due on investors' shares, the investors raised the agent's "fraudulent" assurance of no hability as a defense.

It is easy to understand why the late nimeteenth century courts favored the receiver. The shareholders' collective obligation to pay the remaming $80 \%$ of the par value of their shares represented, in effect, the insurance company's reserve against the contingency that losses might

103. Providing this assurance was probably a high priority for a legal system still coming to grips with the notion of limited liability. The courts' methods of obtaining this assurance were the trust-fund metaphor, see supra notes 17-18 and accompanying text, and the "holding out" concept of the Hospes case. See Hospes v. Northwestern Mfg. \& Car Co., 48 Minn. 174, 50 N.W. 1117 (1892); see also supra text accompanying note 19. Hospes did not involve a defrauded shareholder but the liability of recipients of so-called "bonus" stock, that is, common stock given gratuitously to investors but nonetheless reflected in the corporation's capitalization at an amount equal to its par value. The court concluded that because the corporation had held itself out to creditors as having paid-in capital that included the bonus stock, the recipients of that stock should be liable to creditors for the amount of its par value.

104. Most of the cases arose from the failure of the Great Western Insurance Co. See Chubb v. Upton, 95 U.S. 665 (1877); Upton v. Tribilcock, 91 U.S. 45 (1875); Upton v. Englehart, 28 F. Cas. 835 (C.C.D. Iowa 1874) (No. 16,800); Upton v. Hansbrough, 28 F. Cas. 839 (N.D. II. 1873) (No. 16,801). Upton was the assignee for the benefit of Great Western's creditors. The company was originally organized in lllinois in 1857 with a capital of $\$ 100,000$, but its capital stock was increased to $\$ 5$ million in connection with a reorganization in 1870 . Of this, $\$ 1,188,900$ was subscribed and $\$ 223,000$ paid in. The company's finances were ruined by the great Chicago fire of October 8-9, 1871. Subscribers sought to escape hability on various grounds in addition to that of the agent's fraud. See also Webster v. Upton, 91 U.S. 65 (1876); Sanger v. Upton, 91 U.S. 56 (1875); Upton v. Jackson, 28 F. Cas. 844 (C.C.W.D. Mich. 1874) (No. 16,802) (involving defenses other than fraud). The courts upheld bability in every reported decision. See also Sawyer v. Hoag, 84 U.S. (17 Wall.) 610 (1873); Payson v. Withers, 19 F. Cas. 29 (C.C.D. Ind. 1873) (No. $10,864)$ (decisions on similar facts). 
exceed premium payments. ${ }^{105}$ The prospective policyholder's willingness to deal with the corporation probably depended largely on the existence and integrity of the reserve, and courts therefore attached a high priority to immunizing this reserve from shareholder defenses. ${ }^{106}$

The position of the prospective creditor in a contemporary business financing decision is different, however, from that of the Great Western policyholder. The sophistication in both financial practice and financial law that has evolved since the subordination doctrine originated has considerably undercut the policy arguments for assuring the business creditor protection from the prospect of securities law claims by shareholders. First, the characteristics of the parties have changed; the typical class of shareholders has shifted from a small group of entrepreneurs and local investors to a dispersed public body. Most contemporary shareliolders lack any means to familiarize themselves with the financial affairs of the issuer other than through its pub-

105. See the discussion of this early form of insurance company financing in Oglivie v. Knox Ins. Co., 63 U.S. (22 How.) 380, 387-88 (1860).

106. Undoubtedly the courts also found the equities of the subscriber in this kind of case far from compelling. Although the agent's assurances inight be characterized by the subscriber as a fraud, the facts shade easily into the general body of law concerning side agreements between agent and subscriber, and the closely related notions of bonus and discount shares, that the courts refused to protect. See Sawyer v. Hoag, 84 U.S. (17 Wall.) 610, 620-21 (1873); 1 W. CooK, supra note 99, $\$ \$ 135-38 ; 1$ V. Morawetz, a Treatise on the LaW of Private Corporations $\$ \$ 83$, 87 (2d ed. 1886); 2 id. \& 842 .

Most of these cases arose out of the initial capitalizations of smaller companies and involved subscriptions solicited through face-to-face transactions by corporate agents and promoters. The services of the investment banking industry were reserved for the bonds and preferred shares of the railroads and the larger industrial coinbinations. See V. CArosso, supra note 100, at 29-50. The courts may have feared that allowing the subscriber's own recollection and testimony concerning the agent's oral representations of the subscriber's liability, the amount of other capital committed, and the likely success of the venture to provide the basis for rescission would seriously jeopardize the integrity of stock subscriptions generally. $C f$. the Cook quotation supra at note 99. In addition, the courts may have been influenced by continuing notions of caveat emptor with respect to anyone who would purchase something as speculative as common stock. See Hawkins, supra note 102, at $141 ;$ \%. A. BERLE, CASES AND. MATERIALS IN THE LAW OF CORPORATE F!NANCE 236 (1930) ("Conservative people bought bonds. The common stockholder was regarded as a gambler who was content to take a chance.").

Some courts also disfavored shareholders by stiffening the elements for recovery such as reliance and a misrepresentation of fact. See 1 W. CooK, supra note 99 , $\$ \$ 135-65 ; 1$ V. MORAWETZ, supra note $106 \$ 8$ 94-108. For example, as an illustration of the principle that statements constituting opinions or promises (as opposed to representations of fact) will not provide a basis for rescission, Morawetz in his treatise notes that:

a statement made by an agent obtaining subscriptions for shares in a railroad company, to the effect that the proposed road would be built upon a certaim route or within a certain period of time, would not render a subscription made upon the faith of it voidable, though the stateinent be made with the intention to deceive, and the road be not built upon the route or within the time indicated.

1 V. MORAWETZ, supra, 898 , at 97 (footnote omitted). Morawetz cites 10 cases in support of this proposition. 
lished reports and the financial press. The class of creditors, on the other hand, although it includes many comparatively small claimants in the form of trade creditors and individual holders of the debtor's bonds and debentures, is likely to be dominated by large financial institutions. As a result, the comparative abilitics of the debt and equity classes to protect themselves from fraud and to rcpresent their interests vigorously im a bankruptcy proceeding may have flipflopped since the late nineteenth century. ${ }^{107}$

Second, the factual premise of the nineteenth century position, that a corporation's share capital was the basis for its credit, ${ }^{108}$ no longer fully describes how business creditors behave. The modern business creditor has much broader sources of insight into the corporation's financial condition ${ }^{109}$ and a more refined appreciation for the particular financial characteristics that reflect an ability to repay debt. Short-term creditors are far more concerned with the security underlying the loan and the corporation's short-run liquidity than its long-run capital structure. Trade creditors in particular typically place more emphasis on past experience with the debtor and its reputation in the commercial cominunity than on an analysis of its financial condition. ${ }^{10}$ Long-term lenders continue to look at a corporation's equity cushion, as measured by indicators such as the debt-equity ratio, as an important source of protection; but it has become only one of several factors in the lending decision. These lenders are necessarily futureoriented: they want to know whether the business corporation's prospects will allow it to generate ample cash flow to cover its debt service. As Bayless Manning has noted, the experience of the 1930s demonstrated to creditors that "enterprise debt is not ultimately paid out of

107. Congress has recognized the shifting characteristics of the shareholder and creditor classes and the resulting diminished need for the absolute priority rule. See H. R. REP. No. 595, 95th Cong., 1st Sess. 222 (1977), reprinted in 1978 U.S. CodE CoNG. \& AD. News 5963, 6181,

108. See supra note 101.

109. For 2 description of the primitive state of financial reporting practices in the last half of the nineteenth century and the reluctance of businessmen, stemming from an era of closely-held enterprise, to make financial information available to outsiders see $R$. FouLKE, supra note 100, at 12-23; Hawkins, supra note 102, at 135-45.

110. See B. Manning, supra note 18, at 91-95. For a good discussion of trade credit practices see Note, Eguilable Subordination of Shareholder Debit to Trade Creditors: A Reexamination, 61 B.U.L. Rev. 433, 442-43 (1981) and authorities cited therein. Bur cf. Jean, How Business Credit Grantors Rate Their Banks, J. CoM. BANK LENDING, Mar. 1982, at 40, 42 (indicating that most trade creditors obtain and enploy financial statement information but also stating, "Although both banks and the trade spread and thoroughly analyze entire financial statements to assess creditworthiness, their analysis of repayment ability is sometimes focused on different areas. For example, the trade is always repaid out of working capital while banks often analyze cash flow over extended periods to determine a coinpany's ability to repay long-term financing."). 


\section{balance sheet assets but rather out of operating profits."111}

Third, shareholders' equity accounts have lost much of their nineteenth century sanctity. This loss presumably represents the law's response to changes in the way creditors assess financial risk. The widespread adoption of low-par and no-par shares-an event initially perceived by inany as a serious threat to creditor protection ${ }^{12}$ - and the use of retamed earnings as a financing device ${ }^{113}$ have weakened the

111. B. MannING, supra note 18 , at 14. The views of lenders tend to corroborate Manning's statement. See Jean, supra note 110, at 42. A survey of senior lending officers conducted under the auspices of Robert Morris Associates, a trade group, obtained the following pertinent lenders' views of various attributes of term loans-defined for purposes of the survey as unsecured commercial loans with maturities from 3 to 10 years:

Obviously, in general, short term credit is repaid from seasonal movements, while term

loans depend upon realization of projected earnings in the majority of cases. . . . We have had some difficulty with term loans, particularly where they were essentially capital credits to busimesses with inadequate record-of earnings. Term loans are harder to analyze correctly masmuch as the primary einphasis has to be on profit projection rather than balance sheet analysis and I think it probably will always be true that there will be more hazard in the long term credits.

Term Loans, Bull. RoBT. MoRris Assocs., July 1957 Supp., at 11.

112. New York first allowed the use of shares without par value. This development, in 1912, brought directly into question the utility of the legal capital system as a response to the way creditors really behave. To many observers no-par stock signalled the law's wholesale abandonment of the protection previously afforded creditors through the trust-fund and holding-out theories. See Johnson v. Louisville Trust Co., 293 F. 857, 862 (6th Cir. 1923), cert. denied, 264 U.S. 585 (1924); A. Berle \& G. Means, The Modern Corporation and Private Property 254 (1932); Bonbright, The Dangers of Shares Without Par Value, 24 Colum. L. REv. 449 (1924); Cook, Srock Without Par Value, 7 A.B.A. J. 534, 534 (1921); Warren, The Progress of the Law: Corporations, 34 HARv. L. REv. 282, 286 (1921). By permitting the board of directors to allocate a portion of the amount paid for shares to "surplus", and thereby render it eligible for return to the shareholders, and by raising doubt about the shareholder's liability for watered stock, the acceptance of no-par produced results clearly inconsistent with the nineteenth century idea of nominal capital as a sacrosanct fund. No-par was defended on the grounds that the corporation's credit did not depend on its nominal capital; prospective creditors were much more interested in its present financial condition and the track record of its managenent. See Ballantine, Stockholders' Liability in Minnesota, 7 MinN. L. REv. 79, 89-90, 96 (1923); Goodbar, No-Par Stock-Its Nature and Use, 3 Miami L.Q. 1, 12-13 (1948); Rice \& Harno, Shares With No Par Value, 5 MinN. L. Rev. 493, 494-95 (1921); Stevens, Stock Issues Under the Uniform Business Corporation Act, 13 CoRnelL L.Q. 399, 411-12, 417-18 (1928); Report of Committee on a Uniform Incorporation Act, HaNDBOOK of Nat'l CONF. OF COMm'rs on UNiform State laws and Proceedinos of 30th ANN. CONF. 144 (letter of Arthur W. Machen, Jr., draftsman of the seventh tentative draft). The evolution of financial accounting practices and the increased willingness of busimesses to provide financial statement information facilitated this position, see supra note 109 (authorities cited), and it carried the day, both with the state legislatures and the businessmen. Corporate promoters and inanagers, who would presumably have little incentive to employ a financing device that would deter credit, made immediate and widespread use of no-par. See 1 A. Dewing, The Financial POLICY OF CORPORATIONS $59 \mathrm{n}$.f (5th ed. 1953) (table indicating authorized classes of par and nopar stock contained in new charters of large corporations for the period 1915-1932).

113. For an indication of the importance of retained earnings as a financing source see FED. RES. BuLL., Jan. 1982, at A36-A37, tables $1.47 \& 1.49$. For the years 1978 through 1980 the undistributed profits of United States corporations were \$95.7, \$117.6 and \$107.2 billion respectively. Total after-tax profits were $\$ 140.3, \$ 167.7$ and $\$ 163.2$ billion respectively, for an average 
creditor's technical right, under state law, to claim reliance on the full amount of the shareholders' equity account as a source of protection. For example, consider a shareholder who purcliases, for $\$ 49$, a share of a corporation whose capitalization consists of one million shares of $\$ 1$ par value stock. Its shareholders' equity, to use pre-1979 Model Business Corporation Act terminology, 114 is $\$ 1$ million in stated capital, \$26 million in capital surplus and $\$ 22$ million in earned surplus, for a total of $\$ 49$ million. 115 Under most contemporary state statutes, the only amount upon which the creditor is truly entitled to rely on as an equity cushion is the stated capital, equivalent to $\$ 1$ per share. 116 Thus, under

retention ratio of $68 \%$. By contrast, the annual gross proceeds from new issues of securites for the same period were \$47.2, \$51.5 and $\$ 73.7$ billion respectively.

114. Model Business CoRp. ACT 8 2(j), (l), (m) (1969 rev.) (repealed 1979).

115. The relative amounts of these accounts were derived from the last audited balance sheet of Equity Funding prior to its bankruptcy. The high proportion of surplus is not unusual for the contemporary corporation. See generally W. CarY, Cases and Materiais on Corporations 1484-85 (4th ed. unabr. 1969).

116. Provided the corporation is not insolvent at the time of or immediately after the distribution-in the equity sense of not being able to pay its debts as they come due, see MODEL. Business CoRp. ACT \& 2(n) (1969 rev.) (repealed 1979); CAL. CORP. CODE $\& 501$ (West 1977); N.Y. Bus. CoRp. LAW \& 102(a)(8) (McKinney 1963)-the entire $\$ 22$ million of earned surplus could be distributed to shareholders as a dividend. See MODEl. Business Corp. ACT 845 (1969 rev.) (amended 1979); CAl. CoRP. Code 8 500(a) (West 1977); Del. CODE ANN. tit. 8, \& 170(a)(1) (rev. 1974); N.Y. Bus. CoRP. LAw \& 510(a), (b) (McKinney 1963 \& Supp. 1982-83). Most states would also allow a distribution of the $\$ 26$ million capital surplus. See MODEL Bus. CoRP. ACT $\$ 46$ (rev. 1969) (amended 1979); DEL. CODE ANN. tit. 8, 8 170(a)(1) (rev. 1974); N.Y. Bus. CoRP. LAW 8 510(a), (b) (McKinney 1963 \& Supp. 1982-83); 6 . CAL. CORP. CODE 8 500(b) (West Supp. 1981) (requiring, in general, that after the distribution (1) tangible assets be at least 1.25 times liabilities and (2) current assets be at least equal to current liabilities). Thus, the only true equity cushion remaining is the $\$ 1$ million in stated capital.

Even this amount is not necessarily sacred. The corporation's board and shareholder could adopt resolutions reducing the par value of the shares to, for example, 106 per share and thereby reduce stated capital to $\$ 100,000$. The remaining $\$ 900,000$ becomes capital surplus eligible for distribution to shareholders. See MODEL BusINESS CORP. ACT $\$ \$ 88$ (e), 69, 70 (rev. 1969). (In 1979 section 58(e) was amended and sections 69 and 70 were repealed); $c f$. Del. CODE ANN. tit. 8. 88 242(a)(3),(b), 244(a)(4) (rev. 1974); N.Y. Bus. CoRP. LAw $\$ \$ 801(\mathrm{~b})(10), 802(a)(1)$ (McKinney 1963). For comments on the availability of capital reductions as a basis for distributions to shareholders see W. Cary \& M. Eisenderg, Cases and Materials on Corporations 1381-83 (5th ed. unabr. 1980); D. Herwirtz, Business Planning 350-52, $358-59$ (1966); B. Manning, supra note 18, at 67-68, 70. New amendments to the Model Business Corporation Act weaken this statutory protection even further by abandoning the concept of stated capital and permitting distributions to shareholders so long as (1). the corporation is not insolvent in the equity sense and (2) a balance sheet test, requiring post-distribution assets to be at least equal to liabilities plus liquidation preferences on any senior equity securities, is satisfied. MODEL BusINEss CORP. ACT \& 45(b) (1979).

Professor Clark has pointed out that, notwithstanding the above analysis, fraudulent conveyance law may preserve soine minimum equity cushion for creditors by permitting then to recover from shareholders any distribution leaving a corporation with "unreasonably small capital." Sce Unaform Fraudulent ConveYance ACT 85 (1918); 11 U.S.C. \& 548(a)(2)(B) (ii) (Supp. V 1981). This requirement, Clark argues, remains independent from and in addition to those provided by the legal capital statutes. Clark, supra note 74, at 55460. Compare CAL. CORP. CODE 
the strict logic of the reliance rationale, any securities law claim of the shareholder should be subordinated only to the extent it exceeds $\$ 48$.

Admittedly, many long-term lenders do not limit themselves to this minimal state-law protection against dissipation of the equity cushion and have developed customized contractual arrangements to limit the distribution of assets to shareholders. ${ }^{117}$ The parties to such agreements and indentures inay properly claim "reliance" on something greater than the state-mandated minimum capital, but this private contractual arrangement with the debtor provides hittle doctrinal support for mandating across-the-board subordination of securities law claims. ${ }^{118}$

Notwithstanding these historical changes, would the contemporary business creditor regard the subordination doctrine as a material source of protection? Most creditors probably would not, simply because subordination covers only priority in bankruptcy, a comparatively minor aspect of the value of equity capital to corporate creditors. The primary function of equity capital in the leveraged firm is to buffer the creditors against exposure to business risk by providing for a part of the corporation's value that inay be depleted by business losses without threatening the corporation's ability to pay creditors in full. As we have seen, the subordination doctrine does little to protect this cushion aspect of the debt-equity relationship because prior to bankruptcy, se-

\$ 506(d) (West 1977) (apparently adopting Clark's position) with MODEL Business CoRp. ACT 8152 (1979) (optional provision that legal capital rules supersede all other state law on distributions) and Committee on Corporate Laws, Changes in the Model Business Corporation ActAmendments 10 Financial Provisions, 34 Bus. LAw. 1867, 1889 (1979) (drafters' comment on MBCA \& 152). .

117. See American Bar Foundation, Commentaries on Indentures $401-421$ (1971); W. CARY \& M. EISENBERG, supra note 116, at 1391-95; B. MANNing, supra note 18, at 96-107; Kummert, State Statulory Restrictions on Financial Distributions by Corporations 10 Shareholders Part 1 , 55 WaSH. L. REV. 359, 395-96 (1980). On the frequency of such covenants see Castle, Term Lending-A Guide 10 Negotiating Term Loan Covenants and Other Financial Restrictions, $63 \mathrm{~J}$. CoM. BANK LeNDing, Nov. 1980, at 26, $32-33$ (reporting results of survey by Chemical Bank of 37 term loan agreements with industrial and transportation companies rated by Moody's; of these 23 [62\%] contained restrictions on dividends); Kummert, supra, at $374 \mathrm{n.63}$ (reporting results of survey of 100 corporations selected at random from Moody's Intistrial Mamual; of the 98 corporations that had long-term debt all but 12 had some form of restriction on cash dividends to shareholders); Smith \& Warner, On Financial Contracting: An Amalysis of Bond Covenants. 7 J. FIN. EcoN. 117, 131 n.28 (1979) (citing the findings of an unpublished Ph.D. thesis that out of a randoin sample of 100 industrial firms, all had a dividend restriciton on at least one debt instrument).

118. Presumably, no one would seriously argue that shareholders in a solvent corporation would be barred from collecting upon a securities law class action juidgment solely because payment of the judgment would cause the corporation to be in default under some of the provisions in its various loan agreements. If the croditors' contractually-based reliance is insufficient to permit them to immunize themselves against the risk of securities law claims in the case of the solvent corporation, there is no reason why the result should be different once the corporation enters bankruptcy. 
curities law claimants can withdraw value from the corporation at any time. ${ }^{119}$

The subordination doctrine actually removes only one class of business risks, securities law claims, froin the possible sources of competing claims in bankruptcy. Realistically, protection against this risk is unlikely to figure inaterially in the deliberations of a prospective lender. For a lender to receive any benefit from the subordination rule, three events have to occur: (1) the debtor must commit a fraud or some other securities violation on a scale that entitles its securityholders to obtain a judgment agamst it for a material ainount; (2) the debtor must become bankrupt; and (3) the securityholders must fail to discover and hquidate their claims prior to bankruptcy. If the typical prospective creditor views this combination a likely contingency of the debtor, it will not seek comfort within the confines of the subordination rule; it will refuse to inake the loan. 120

3. Conclusions About the Reliance Rationale. In sun, for the reliance rationale to afford a satisfactory basis for treating a creditors' risk of securities law claims against the debtor differently from risks of other competing claims over the course of a loan, one of two conclu-

119. See supra text accompanying notes 87-89.

120. Admittedly, some marginal lending decisions may be affected by the subordination doctrine's applicability. Consider a bank loan to a small, unproven company when the lender is willing to take the risk because of the prospects for future growth and business. The bank discovers that the company has committed "rechnical" violations of the registration or other requirements of state and federal securities law at the time of its initial capitalization, a not infrequent occurrence in companies lacking highly experienced securities counsel, see A. CONARD, CorPorations in Perspective 47 (1976); C. Israels \& G. Duff, When Corporations Go Public 52 (1962) (comment of D. Henkel); Bromberg, Curing Securities Violations: Rescission Offers and Other Techniques, 1 J. CoRp. L. 1, 13 (1975), with the result that those who purchased shares as a part of this capitalization have a statutory right to rescind and recover the money they paid, see Securities Act \& 12, 15 U.S.C. \& 771 (1976); Uniform Securities Act \& 410(a). The bank realizes that as long as the company's fortunes continue to climb the shareholders have no incentive to rescind, but in view of the company's youth and the riskiness of its business, the bank cannot rest assured that the prosperity will continue forever. Even here, however, the subordination rule is not clearly critical to the bank's ability to protect itself against shareholders' rescission claims. If the grounds for rescission involve only registration violations, the statute of limitations is relatively short; the period under the federal Securities Act is one year from the date of the violation. Securities Act \& 13, 15 U.S.C. $877 \mathrm{~m}$ (1976); of. Uniform Securities Act $\$ 410(c)$ (two years from sale). If the statute still has a substantial time to run, the bank may choose to foreclose securities law claims by insisting that the company make a rescission offer to potential claimants, a relatively common practice in other contexts. See generally Bromberg, supra. There is some doubt whether this practice is effective to extinguish the rights of those who fail to accept the offer. Compare UNIFORM SECURITIES ACT \& 410(e) (rights extinguished by nonacceptance); FEDERAI SECURITIES CODE 8 1727(g)(l)(1978) (similar) with Meyers v. C\&M Petroleum Producers, Inc., 476 F.2d 427 (5th Cir.) (no extinction of federal rights for failure to accept 10-day rescission offer, case may turn on the short time period as opposed to an unconditional offer of rescission), cert denied, 414 U.S. 829 (1973). Both the statute of limitations and the voluntary rescission offer provide the bank more protection than the subordination doctrine, which is triggered only in bankruptcy. 
sions must be made. Either the rationale reflects the implied understandings of both creditors and shareholders, or it lias a beneficial impact on the cost or availability of busmess financing. There is little evidence to support the first proposition. As to the second, any detrimental impact on the cost or availability of debt financing resulting from a rule of parity may be offset by a commensurate beneficial impact on the cost and availability of equity financing. Further, a realistic appreciation of the limited effect that the subordination doctrine has on the risks faced by prospective business lenders inakes it unlikely that the doctrine would have any material impact on most credit decisions. 121

\section{The "Best-of-Both-Worlds" Rationale.}

The second principal argument made in support of the subordination doctrine assesses the risks voluntarily assumed by a shareholder. In a leveraged firm equityholders accept a junior position in excliange for the exclusive right to all assets in excess of the amount necessary to satisfy the fixed claims of creditors. If the firm prospers, creditors cannot renounce their status and share this increased value with the equityholders. Supporters of subordination argue, therefore, that if the firm fails, equityholders should not be permitted to enploy the federal securities laws to participate on a par with creditors. Because this argument is concerned with the seeming unfairness of permitting shareholders to switch to creditor status, it will be referred to as the best-of-both-worlds rationale.

Like the reliance rationale, this argument lias a long history. As one of the leading American decisions of the late-nineteenth century put it: "[w]hen a corporation becomes bankrupt the teinptation to lay aside the garb of a stockholder, on one pretense or another, and to assume the role of a creditor, is very strong, and all atteinpts of that kind should be viewed with suspicion."122

Because of this concern, many of the early American courts, although phrasing their opinions in the conventional terms of lacles and

121. Consider Professor Shuchman's general comments:

[W] do not know too much about the actual impact on creditors' costs of most legislative changes that appear to increase legal risk in credit transactions, at least as regards those that are within the range gencrally attempted, excluding the usual extreme hypothetical changes. ... The potential risk in the bankruptcy law may only be realized in the relatively few loans that result in both default and bankruptcy; and the actual costs of the realized risk are diffeult to determine and probably not often calculated by lenders.

Shuchman, Theory and Reality in Bankruptcy: The Spherical Chicken, 41 Law \& Contemp. ProBs., Autumn 1977, at 66, 94 (footnotes omitted).

122. Newton Nat'l Bank v. Newbegin, 74 F. 135, 140 (8th Cir. 1896). 
similar equitable doctrines, ${ }^{123}$ required unusually rigorous diligence when faced with a shareholder's atteinpt to rescind postdated insolvency. ${ }^{124}$ This suspicion of shareholders who atteinpted rescission unay explain why these courts were nonetheless willing to allow sliareliolders to obtain relief if they had taken some initial step to rescind prior to the commenceinent of formal insolvency proceedings. ${ }^{125}$

Slain and Kripke do not focus on shareholder behavior, however. They focus on what they regard as two distinct risks inherent in the conflict between contract creditors and securities law claimants: (1) the risk of insolvency, from whatever cause; and (2) the risk of securities

123. See supra note 15 and accompanying text.

124. See Farrar v. Walker, 8 F. Cas. 1076, 1078 (C.C.E.D. Mo. 1875) (No. 4,679); Duffield v. E.T. Barnum Wire \& Iron Works, 64 Mich. 293, 301-03, 31 N.W. $310,314-15$ (1887) (affirming a lower court decision on a 2-2 vote); Dunn v. State Bank, 59 Minn. 221, 228-29, 61 N.W. 27, 28-29 (1894); Martin v. South Salem Land Co., 94 Va. 28, 52-56, 26 S.E. 591, 598-99 (1897). These authorities suggest that the rescinding shareholder had an affirmative duty to investigate the company's financial condition, including exercising his right to examine corporate books and records. See also In re Recording Devices Co., 1 F.2d 474, $476-77$ (S.D. Ohio 1924) (language to similar effect). But see Hinkley v. Sac Oil \& Pipe Line, 132 lowa 396, 409-10, 107 N.W. 629,634 (1906); Duffield v. E.T. Barnum Wire \& Iron Works, 64 Mich. at 306-07, 31 N.W. at 316 (dissenting opinion). As a result, a shareholder holding his shares for more than a few months after a fraud faced an almost insurmountable burden in proving that he had acted with the requisite promptness. By contrast, the traditional laches standard places the buyer under no general duty to investigate and requires him to take action only if sufficient facts come to his attention to put him on notice that an inquiry is needed. 3 L. Loss, Securities Regulation 1677 (2d ed. 1961); Friedman, Delay as a Bar 10 Rescission, 26 CoRNell L.Q. 426, $432-34$ (1941). Contemporary civil antifraud liability under the federal securities laws sets a comparable "inquiry notice" standard in determining when the statute of himitations period begins to run. See Cook v. Avien, Inc., 573 F.2d 685, $694-98$ (Ist Cir. 1978); Johns Hopkins Univ. v. Hutton, 488 F.2d 912, 917-18 (4th Cir. 1973), cert. denied, 416 U.S. 916 (1974); Dale v. Rosenfeld, 229 F.2d 855, 858 (2d Cir. 1956).

125. See Goess v. A.D.H. Holding Corp., 85 F.2d 72 (2d Cir. 1936); Hinkley v. Sac Oil \& Pipe Lime Co., 132 lowa 396, 410-12, 107 N.W. 629, 634-35 (1906); Fear v. Bartlett, 81 Md. 435, 32 A. 322 (1895); Savage v. Bartlett, 78 Md. 561, 28 A. 414 (1894); Gordon v. Ralston, 155 Ore. 310, 31516,62 P.2d 1328, 1330 (1936). Even the English courts, which lad adopted an absolute rule barring rescission after winding-up, see supra notes $10-12$ and accompanying text, made the same exception. Reese River Silver Mining Co. v. Smith, 4 L.R.-E. \& I. App. 64 (1869). In the American cases, the exception appeared to apply even if the issuer was insolvent at the time of rescission, so long as formal proceedings had not yet commenced. See Hinkley v. Sac Oil \& Pipe Line Co., 132 lowa at 410-12, 107 N.W. at 635; Fear v. Bartleth, 81 Md. at 444, 32 A. at 323 (dicta). But see Tennent v. City of Glasgow Bank, 4 App. Cas. 615 (1879) (Scot.) (rescission barred when shareholder brought suit prior to winding-up but after it had become pubhic knowledge that the issuerbank had stopped payment). Permitting the shareholder to rescind in these cases could decrease the recovery of contract creditors who may have relied upon his subscription. In this sense, the "best-of-both-worlds" concern-or more accurately the lack of it-supercedes the rehance concern. The lack of any best-of-both-worlds problem may also help explain Oppenheimer v. Harriman Nat'l Bank \& Trust Co., 301 U.S. 206 (1937). See supre notes 26-32 and accompanying text. The plaintiff in Oppenhelmer lad acknowledged and satisfied his statutory liability, thus he could not be hedging his bets at the expense of creditors by secking to participate as a general creditor. 
law violations. ${ }^{126}$ They argue that the absolite priority rule reflects the different degrees to which creditors and stiareholders assume the first risk and that there is no obvious reason for reallocating it through the mechamism of securities law claims. ${ }^{127}$ The traditional securities law remedies of rescission and deceit-based damages provide a basis for illustrating this potential reallocation of investment risk. The equitable remedy of rescission, which is encountered repeatedly im the historical development of the subordination doctrine, permits a defrauded shareholder to return to his pre-investment position by tendering his shares to the seller in return for the consideration paid. ${ }^{128}$ The common law tort action in deceit ${ }^{129}$ permits the shareholder to recover damages equal to the difference between the amount he paid for his shares ${ }^{130}$ and their true value at the time of purchase. To a considerable extent investors' statutory remedies under modern state and federal securitics laws are derived from these two basic forms of relief, so a problein exploring their effects will help assess the best-of-both-worlds reallocation concern raised by Slain and Kripke.

Suppose a group of promoters has recently organized Diversified Mining Company (DMC) around two assets, a copper mine and a silver mine, each valued on DMC's books at $\$ 500,000$. The promoters set the company's capitalization at $\$ 1$ million, consisting of 10,000 shares of coininon stock. Half the stock will be sold to the public at $\$ 100$ per share and half retained by the promoters. As it begins business, DMC has no liabilities.

126. See Slain \& Kripke, supra note 44, at 286-88; Kelce v. U.S. Fin., Inc., 648 F.2d 515, 520 (9th Cir. 1980), cert. denied, 451 U.S. 970 (1981); Jezarian v. Raichle (In re Stirling Homex Corp.), 579 F.2d 206, 214 (2d Cir. 1978), cert. denied, 439 U.S. 1074 (1979); H. R. REP. No. 595, 95th Cong., 1st Sess. 195 (1977), reprinted in 1978 U.S. CODE CoNG. \& AD. NEws 5963, 6156.

127. For the arguments concerning the second risk see infra text accompanying note 198.

128. See generally 1 F. HARPER \& F. JAMES, THE LAW OF TORTS \& 7.15, at 603-05 (1956); 3 L. LOSS, supra note 124, at 1626-27; W. PROSSER, HANDBOOK OF THE LAW OF TORTS 8105 , at $685-87$ (4th ed. 1971); RESTATEMENT OF RESTITUTION $\$ 8$ 8, 28 (1937).

129. See generally 1 F. HARPER \& F. JAMES, supra note 128, \& 7.15; 3 L. Loss, supra note 124, at 1628-30; W. PROSSER, supra note 128, $\$ 150$, at 685-87; RESTATEMENT (SECOND) OF TORTS $\S \$ 525-49$ (1976).

130. In some cases the shareholder could recover the amount the shares were represented to be worth if this were higher than the amount he paid. This raises the distinction between out-ofpocket and benefit-of-the-bargain damage measures in deceit actions. The first Restatement of Torts adopted the out-of-pocket rule and limited plaintiff' recoveries to the differenee between the amount paid for the security and its actual value, RESTATEMENT OF TORTs $\$ 549$ (a) (1938), on the grounds that deceit actions sounded in tort, the purpose of which was to compensate the victim for his actual loss. The vast majority of American courts, however, adopted the more generous benefit-of-the-bargain ineasure of recovery. As a result, the Restateinent (Second) of Torts permits this additional recovery in business transactions if proven with reasonable eertainty. RESTATEMENT (SECOND) OF TORTS 8549 (2) comment $g$ (1976); id, Note to Institute (Tent. Dran No. 11, 1965). 
DMC's public offering prospectus stated that each mine's $\$ 500,000$ valuation resulted from independent appraisals. The prospectus also contained glowing reports of the projected output of the mines, again purportedly on the basis of independent appraisals. In fact, although the statements about the copper mine are true, those about the silver mine are total falsehoods. The promoters purchased the silver mine for $\$ 5,000$ one month before forming the corporation and never bothered to obtain an independent appraisal because the property appeared worthless. The first year of the mines' operation confirms that the silver mine is worthless, and a precipitous and unexpected fall in the price of copper causes the copper mine, though productive, to become unprofitable. Its working capital exhausted, DMC ceases operations and enters bankruptcy. At this point Alphonse, an investor who purchased 100 shares of DMC stock in the public offering, learns of the misrepresentations and seeks to rescind and recover the $\$ 10,000$ he paid for his shares.

Consider Alphonse's economic position immediately before and after his purchase of stock. Before, lie had $\$ 10,000$ cash. After, he has shares representing a $1 / 100$ interest in a copper mine worth $\$ 500,000$ and a 1/100 interest in another piece of real estate worth no inore than $\$ 5000$, a total value of $\$ 5050$. As a result of the purchase, Alphonse suffers an immediate and tangible loss of $\$ 4950$. This "fraud loss" corresponds to the second of the two risks identified by Professors Slain and Kripke: the risk of securities law violations. The further erosion of Alphonse's investment because of the decline in the copper market is, on the other hand, a "busmess loss" that corresponds to the first of the risks identified by Slain and Kripke: the risk of insolvency.

If Alphonse obtains restitution of his full $\$ 10,000$ purchase price, he receives compensation for both of these losses. This would appear to permit Alphonse improperly to evade the risk of an uncertain copper market. Alphonse assumed the risk of loss resulting from that weak. market as a quid pro quo for the opportumity he had to benefit froin a favorable one. In short, allowing him to use the rescissory remedy to recoup this business loss along with his fraud loss would give Alphonse the best-of-both-worlds.

Alphonse may respond that he could not have given his full, cognitive consent to the risks of business loss inherent in DMC because he had invested on the basis of defective inforination. ${ }^{131}$ If Alphonse must bear the busmess loss portion of his total losses, the law has treated him

131. The SEC has made essentially this argument. See SEC REPORT ON BANKRUPTCY REV1SION, 1975 Senate Hearings supra note 3, at 759-60; SEC REPORT ON BANKRUPTCY REVISION, 1976 House Hearings supro note 3, at 2184-86. 
like an investor who voluntarily decided to pay $\$ 5050$ in exchange for a $1 / 100$ interest in a copper mine and a $1 / 100$ interest in nonmining real estate. But nothing indicates that Alphonse would have knowingly consented to this investment. Perhaps his investment interests lay primarily in silver and DMC seemed an attractive coinpany, notwithstanding its copper activities, because it appeared to offer a good "play" in silver. Alternatively, Alphonse may be an experienced securities analyst who concluded, on the basis of an empirical study of mining stocks, that copper and silver prices have a negative correlation and therefore considered DMC a unique opportunity for low-risk mining investment. In any case, holding Alphonse to his business loss treats him as consentimg to an investment perhaps very different from the one he thought he was making. Rescission avoids such treatment; it provides a remedy for loss of investment choice as well as any loss of investment value caused by securities fraud.

In Alphonse's case, the "cost" of any restitutional rehef he and other pubhic shareholders obtain will fall on nonrescinding shareholders-probably the promoters. Because the promoters induced Alphonse to make the DMC investment, the arguments in the preceding paragraph suggest that they, rather than Alphonse, should bear Alphonse's busimess loss. Rescission achieves this result as long as the promoters' own funds remain at risk.

Suppose, however, that after the public offering, DMC borrowed $\$ 500,000$ from a local bank and used the money to acquire and retire the promoter's stock. Now the cost of restitution will fall in part on the bank. This strengthens the argument that Alphonse should bear the portion of his losses attributable to business risks; although his consent to this risk was tainted, Alphonse did enjoy an opportunity for upside appreciation not available to the bank. This argument, based on the relationship between busimess loss and rescission, is the essence of Slain's and Kripke's objection to any reallocation of insolvency risk; it does not, however, make sense with respect to fraud losses.

Certainly Alphonse did not agree to the risk of being defrauded. ${ }^{132}$ Furthermore, recompensing his fraud losses causes no best-of-bothworlds problem. Because of the fraud, Alphonse suffered a direct and immediate loss of investment value at the time he purchased his shares. As previously suggested, allowing him to recover this $\$ 4950$ fraud loss will place him in the saine position as another inythical investor; Gaston, who knowingly invested $\$ 5050$ to purchase a $1 / 100$ interest in a company owning the copper mine and barren real estate. Alphonse's

132. Id 
opportunity for profit and exposure to loss were never any different from those of Gaston even though Alphonse's expectations were higher because of DMC's falsehoods; therefore, placing Alphonse in the same financial position as Gaston does not allow Alphonse to renounce any risk voluntarily assumed or provide him any unfair advantage vis-a-vis contract creditors. Rather, compensating Alphonse for this fraud loss merely assures that the net price he pays for the package of opportunity and risk he received is the same as what Gaston presuniably would have paid: $\$ 5050$. The traditional deceit remedy accomplishes this through its out-of-pocket measure of daniages. ${ }^{133}$

When the securities involved are actively traded in a public market, permitting Alphonse to recover his fraud loss but not his business loss also responds to another concern embraced by the best-of-bothworlds argument. Suppose that Alphonse never knew of the $\$ 500,000$ appraisal of the silver mine, or that lie knew of it but it did not affect his investment decision. ${ }^{134}$ Arguably, if he would have purchased the DMC shares in the absence of the fraud, permitting him to recover either his fraud loss or his business loss at the company's demise gives him a windfall.

Traditional tort law addresses this problem of causal connection between the fraud and the investor's decisionmaking by requiring objective proof of the materiality of the fraudulent statement and proof of the investor's subjective rehiance on it. ${ }^{135}$ Increasingly, however, courts have dispensed with individual reliance requirements, or have presumed them inet, subject to rebuttal, in cases involving publicly-traded securities by reasoning that the plaintiff relied on the general integrity of the market to assure a fair price. ${ }^{136}$ Two argunients support this

133. The text suggests that the out-of-pocket rather than the benefit-of-the-bargain rule provides the appropriate measure of investor participation. See supra note 130 . Active market transactions in a truly efficient market, see infra note 137, should eliminate the distinction between these two measures. The actions of inforned traders would bring the market price of the security into line with the value suggested by the issuer's representations to the market place. Whether or not a truly efficient market exists, creditors should not have to subsidize investors' unrealized expectations that the security was worth more than they paid for it.

134. This seems unlikely with a fraud as palpable as DMC's, but certainly possible in the more typical exainples of securities fraud by public corporations-such as premature recognition of income or inventory overvaluation-and the modern shareholder who has a variety of information sources and a wide spectrum of reasons for purchasing stock.

135. See REstatement (SECOND) OF TORTS $\$ 8537-38$ (1976); $q$. RESTATEMENT OF RESTITUTION $\$ \S 9(1)$, (2), comment $a$ (1937) (for purposes of restitution, fraud must be the "induceinent" for the transaction; innocent misrepresentation must also be material). The express remedies available under the Securities Act, in contrast, do not impose a direct rehance requirement. Securities Act $\S \S 11,12(2), 15$ U.S.C. $877 k, 771(2)$ (1976).

136. See Panzirer v. Wolf, 663 F.2d 365 (2d Cir. 1981), vacated as moot sub nom. Price Waterhouse v. Panzirer, 103 S.Cl. 434 (1982); Ross v. A.H. Robins Co., 607 F.2d 545, 553 (2d Cir. 
"fraud-on-the-market" theory.

First, many investors depend on the advice of professionals such as brokers, securities analysts, financial colummists and others in making imvestment decisions; thus although the plaintiff may not have relied directly on the fraudulent statement in question, he or she may be actimg on the recommendation of someone who did. Second, there is the efficient-market theory, which holds that the market price of a security impounds all of the publicly available information concerning its value. ${ }^{137}$

This latter point suggests that whether or not Alphonse personally relied on the fraud in making his investment decision, it injured him. Had DMC disclosed the true value of the silver mine, Alphonse would have paid no more than $\$ 5050$ for his shares because the collective actions of informed traders in the market would have tended to hold the price at that average level. Thus, giving Alphonse a damages award that places him in an equal financial position with Gaston represents a truly realistic ${ }^{138}$ reconstruction of the economic position he would have enjoyed but for the fraud.

The example of Alphonse and Gaston demonstrates that the bestof-both-worlds concern arises not so much from the rule of parity and securities law claims in general, but from the particular remedy of rescission. The early court decisions that developed the subordination doctrine dealt almost exclusively with a rescissory reınedy. ${ }^{139}$ Simi-

1979), cert. denied, 446 U.S. 946 (1980); Blackie v. Barrack, 524 F.2d 891, 906-08 (9th Cir. 1975), cert. denied, 429 U.S. 816 (1976); In re LTV Securities Litigation, 88 F.R.D. 134, 142-46 (N.D. Tex. 1980). See generally Fischel, Use of Modern Finance Theory in Securities Fraud Cases Involving Actively Traded Securities, 38 Bus. LAw. 1, 9-10 (1982); Note, The Fraud-on-the-Market Theory, 95 HARv. L. Rev. 1143 (1982). These cases have arisen under rule 10b-S, which otherwise requires plaintiffs to prove reliance when predicating liability on an affirmative misrepresentation.

137. This particular formulation of the efficient-markets hypothesis, that the information reflected by the price of the security imcludes all publicly available information, represents the "semistrong" version of the hypothesis. For general discussions of efficient-markets theory and the evidence supporting it see E. FAMA, FoundaTIONS OF FINANCE 133-68 (1976); J. LORIE \& M. Hamilton, The Stock Market-Theory and Evidence $70-97$ (1973); B. Malkiel, A RanDOM Walk Down Wall Street pt. 2 passim (2d ed. 1981); Fama, Efficient Capital Markets: A Review of Theory and Empirical Work, 25 J. Fin. 383 (1970). For discussion of the implications of the theory for securities law remedies see generally Fischel, Use of Modern Finance Theory in Securities Fraud Cases Involving Actively Traded Securities, 38 Bus. LAw. 1, 9-10 (1982); Pickholz \& Horahan, The SEC's Version of the Efficient Market Theory and its Impact on Securitles Law Liabilities, 39 WASH. \& LEE L. Rev. 943 (1982).

138. If anything the award is conservative in that the alternative assumption is that, absent the fraud, Alphonse would not have purchased the shares at all; in which case only rescission can reconstruct his prior economic position.

139. Several factors unay explain this. First, as in the case of Alplonse, rescission offers a prospect for greater recovery than deceit because it compensates both fraud and business losses. Early cases typically involved a fraud asserted defensively to avoid hability on a share subscrip- 
larly, Professors Slain and Kripke focus on rescission, as the introduction to their article and the references and examples they employ in their analysis indicate. Perhaps if the conflict between contract creditors and defrauded shareholders had arisen principally through assertion of deceit claims, the result would have been different. ${ }^{140}$ Rescission fails to require a causal link between the fraud and the victim's loss and thus permits a best-of-both-worlds choice. The deceit remedy of damages cures this problem by compensating the shareholder for fraud loss but not busmess loss and thereby prevents any after-the-fact renunciation of risk. Consequently, the inost direct and theoretically honest way to address the best-of-both-worlds concern is not through blanket subordination. Instead, securities law claims should be accorded parity, with their participation limited to an amount consistent with investors' out-of-pocket damages and the balance of the claim, if any, subordinated. ${ }^{141}$

tion. Rescission would excuse the shareholder from his subscription. A deceit remedy, on the other hand, would require the subscriber to honor his subscription, with the deceit claim representing either a set-off or, worse, a separate claim against the issuer's limited assets. Second, in Britain, the House of Lords held rescission a prerequisite to a deceit action. See Houldsworth v. City of Glasgow Bank, 5 App. Cas. 317 (1880) (Scot). Because the initiation of winding-up cut off the shareholders' rights to rescind, see supra notes 10-12 and accompanying text, it also cut off deceit actions. Third, in the United States, unliquidated deceit claims were generally held not "provable" under section 63a of the Bankruptcy Act, 11 U.S.C. \& 103(a) (1976), and thus could not participate in a straight bankruptcy, the form most of the early cases took. A rescission and restitution claim, on the other hand, plausibly sounded in quasi-contract, provable under section 63a(4), 11 U.S.C. 8103 (a)(4) (1976), as a claim founded on "a contract express or implied." Allegaent v. Perot, 466 F. Supp. 516 (S.D.N.Y. 1978); Cawthon v. BancoKentucky Co., 52 F.2d 850 (W.D. Ky. 1931); In re Bancunity Corp., 36 F.2d 595 (S.D.N.Y. 1929); see generally Note, Securities Claims in Bankruptcy: Provability and Priority, 53 N.Y.U.L. REv. 1056 (1978). The new Bankruptcy Code generally abandons the requirements of provability. See 11 U.S.C. \$\$502(a), 101 (4) (definition of "claim") (Supp. V 1981).

140. Few cases involved deceit actions, but at least one supports this notion. See Dorsey Mach. Co. v. McCaffrey, 139 Ind. 545, 552-53, 38 N.E. 208, 211 (1894). But see Dennis v. Thompson, $240 \mathrm{Ky} .727,729-30,43$ S.W.2d 18, 19-20 (1931) (applying rescission authorities to a deceit claim without considering the distinction).

141. As a practical matter, the amount of the shareholder's claim against publicly lield corporations may be limited to the out-of-pocket measure by the terms of the available federal securities law remedies. The antifraud remedy applicable to misstatements in registration statements, section 11 of the Securities Act, includes an affirmative defense reducing the plaintiff's damages by the amount of any loss in value that the defendant can prove is attributable to causes other than the misstatements. Securities Act $811(e), 15$ U.S.C. $877 \mathrm{k}(e)$ (1976). Thns, in the DMC hypothetical, if the defendants prove that a portion of Alphonse's loss was caused by the declines in the copper market, the amount of his damages will be decreased accordingly. Also, in the case of the omnibus antifraud remedy, rule 10b-5, courts have limited the plaintif to the out-of-pocket measure of damages when the claim is based on purchases of shares in the open market. Huddleston $v$. Herman \& MacLean, 640 F.2d 534, 553-56 (5th Cir. 1981), affd in part, rev'd in part on other grounds, 103 S.CL. 683 (1983); Green v. Occidental Petroleum Corp., 541 F.2d 1335, 1341-46 (9th Cir. 1976) (concurring opinion); Harris v. American Inv. Co., 523 F.2d 220, 224-27 (8th Cir. 1975), cerh denied, 423 U.S. 1054 (1976); Bonime v. Doyle, 416 F. Supp. 1372, 1384-86 (S.D.N.Y. 1976), 
Also related to the best-of-both-worlds concern is the doctrine of laches. At the heart of the concern is the defrauded shareholder's opportunity to retain his shares if, notwithstanding the fraud, the issuer prospers, but to rescind and demand the return of his investment if it does not. The equitable doctrine of laches responds directly to this concern by requiring the shareholder to decide promptly on discovering the fraud whether he wants to stay in or get out. ${ }^{142}$ Solne securities law remedies are subject to a laches defense, ${ }^{143}$ and there is no reason why it should not apply with equal force once the issuer enters bankruptcy. ${ }^{144}$

Laches does not completely solve the best-of-both-worlds problem, however, because it is triggered only when a fraud is or should have been discovered. Experience suggests that in cases in which the subordination doctrine could be applied, fraud coines to light only on the eve of bankruptcy, if not later. At that point shareholders do not hedge their bets to see whether the issuer recovers, but rather race to the courthouse, seeking to take the lead in any class action litigation. As the DMC problem deinonstrates, a successful action for rescission at

affd mem, 556 F.2d 554, 555 (2d Cir. 1977). The antifraud and nonregistration remedies created by Securities Act $\$ 12$, 15 U.S.C. $\$ 77(1)$ (1976), on the other hand, employ a rescission based measure of recovery. Bnt these remedies, like the equitable remedy of rescission, require contractual privity between plaintiff and defendant. Thus, they will not often be asserted against the publicly leld issuer by shareliolder plaintiffs.

142. For this reason, the laches doctrine functions as an anti-hedging or anti-straddle rule. See Slain \& Kripke, supra note 44, at 293.

143. Several courts predicating rescission on rule $10 \mathrm{~b}-5$ have held that the plamtiffs failure to be diligent in bringing suit bars any resort to the remedy. See Johns Hopkins Univ. v. Hutton, 488 F.2d 912, 915-18 (4th Cir. 1973), cert. denied, 416 U.S. 916 (1974); Baumel v. Rosen, 412 F.2d 571, 574-75 (4th Cir. 1969), cert. denied, 396 U.S. 1037 (1970); Royal Air Properties, Inc. v. Smith, 312 F.2d 210, 214 (9th Cir. 1962); see also Estate Counseling Serv., Inc. v. Merrill Lynch, Pierce, Fenner \& Smith, Inc. 303 F.2d 527 (10th Cir. 1962), in which the court, holding that the plaintiffs actions amounted to an election to rescind, stated:

Where parties have the right to rescind, they cannot delay the exercise of that right to determine whether avoidance or affirmance will be more profitable to them. This is particularly true where the transaction is one of a speculative nature. . . . In the transaction herein involved it would doubtlessly have been more advantageous for the appellant to have had the benefit of claiming a rescission of the contract if a loss was imminent, and to disclaim the rescission if a profit was apparent.

Id. at 532 .

On the other hand, although the nature of the relief sounds in rescission, the Court of Appeals for the Ninth Circuit has held that the defense of laches does not apply to actions under section 12 of the Securities Act; only the statute of limitations bars such suits. Straley v. Universal Uranium \& Milling Corp. 289 F.2d 370, 372-73 (9th Cir. 1961). Of course, a preclusion of rescission, if laches does apply to a cause of action, will not affect a plaintiff's right to damages. Baumel v. Rosen, 412 F.2d at 575 .

144. Slain and Kripke suggest that the equitable nature of bankruptcy jurisdiction improves the technical case for applying the laches doctrine because it undermines the argument that laches should not apply to a remedy at law. Slain \& Kripke, supra note 44, at 293 n.108. 
this point, whether or not viewed as prompt with respect to discovery of the fraud, permits shareholders to deflect the business risks of their investment. As the DMC problem also shows, holding shareholders to their out-of-pocket damages solves this problem. Even assuming that shareholders become aware of a fraud prior to insolvency, they can collect this measure of damages and still continue to bet on the issuer by retaining their shares. Therefore, permitting an out-of-pocket recovery does not represent a reward for hedging at the expense of creditors. For these reasons, limiting recoveries to out-of-pocket damages responds better to the best-of-both-worlds problem than does the laches doctrine. Limiting recovery eliminates the best-of-both-worlds problem because no better world exists for the shareholder to choose.

\section{Creditors as Innocent Nonparties to the Fraud and the "Revolution in Securities Regulation."}

The two preceding sections cover the theories traditionally advanced in support of subordination, but some lesser rationales remain. Although not articulated as clearly as the rehance and best-of-bothworlds rationales, these arguments played a role in the acceptance of the subordination doctrine. Language in soine of the early court opinions ${ }^{145}$ suggests the following line of reasoning. Generally, defrauded shareholders have the right to seek recovery from the assets of the issuer and other persons responsible for the fraud. In insolvency, however, innocent creditors succeed to the beneficial interest in the issuer's assets. Because these creditors, unlike the issuer, were neither parties to the fraud nor responsible for it, its consequences should not "bind". them. Perhaps similar reasoning underlies Slain's and Kripke's contention that creditors should not bear any portion of the risk of illegal securities issuance because the stock was not offered to them. ${ }^{146}$ In any event, this reasoning implies that defrauded shareholders' claims against the assets of an issuer deserve deferral to those of innocent creditors, and that shareholders should seek their recovery from others directly responsible for the fraud, such as the issuer's officers, directors and accountants.

The two sections that follow evaluate this argument from different perspectives. Section 1 examines its substantive logic. Section 2 considers the argument as one part of a larger adverse reaction to the expansion of securities law liability during the 1960s and early 1970s.

145. See, eg., Howard v. Glenn, 85 Gq. 238, 260-61, 11 S.E. 610, 611-12 (1890); Saffold v. Barnes, 39 Miss. 399, 402 (1860); Moosbrugger v. Walsh, 96 N.Y. Sup. Ct. 564, 568, 35 N.Y.S. 550, 552 (App. Div. 1895); Dettra v. Kestner, 147 Pa. 566, 579, 23 A. 889, 890 (1892).

146. Slain \& Kripke, supra note 44, at 288; see also supra text accompanying note 126. 
1. The Inconsistency of the "Innocent Creditors" Argument. The premise that fraud should not "bind" innocent, nonparty creditors has no doctrinal support. Any person with debt or equity clains against an issuer necessarily stands subject to all coinpeting and senior claims that either have arisen or may arise against the issuer by the actions of its agents. The basic principles of authority and respondeat superior establish the issuer's responsibility and hability for the fraud perpetrated by its agents, just as in other tort or contract cases. That the actions of the agent were wrongful or unlawful does not alter their attribution to the issuer. ${ }^{147}$ In this sense fraud "binds" innocent creditors in exactly the saine way as does liability for personal injuries inflicted by the negligent conduct of an issuer's truck drivers or the illadvised decisions of its management to expand into unprofitable lines of business.

When fraud victims recover a judgment against a solvent issuer, the recovery is not at the expense of the issuer except in the most abstract sense, but its common shareholders. ${ }^{148}$ When a modern publiclyheld corporation is involved, any attempt to treat these shareholders as less "innocent" or inore responsible for the fraud than corporate creditors is unjustified. In theory, perhaps the shareholders may be charged with responsibility because they elect the board of directors, which in turn appoimts the officers and other agents. In reality, however, public shareliolders of a corporation usually have little voice in who the managers are or how they behave; a large creditor is likely to have much more control, particularly as the corporation edges toward insolvency. For most public shareholders and creditors alike the only meaningful opportunity for exercising choice of management lies in the so-called "Wall Street rule": the decision whether to invest in the issuer in the first place and whether to get out if the investment becomes unsatisfactory. Fraud taints this choice equally for equity and debt.

Another possible ground for distinguishing antifraud recovery at the expense of corporate creditors from that at the expense of share-

147. See Sharp v. Coopers \& Lybrand, 649 F.2d 175, 184 (3d Cir. 1981), cert. denied, 455 U.S. 938 (1982); RESTATEMENT (SECOND) OF AGENCY \&\& 249, 257-58, 261-62 (1957); cf. id. \& 231 ("An act may be within the scope of employment although consciously criminal or tortious.").

148. Judge Friendly alluded to this problem in his concurring opinion in Texas Gulf Sulfur:

As has been well said. . . "One source of perplexity as to the appropriate bounds of the civil remedy for misleading filings is that any remedy imposed against the issuer itself is indirectly imposed on all holders of the common stock, usually the most important segment of the total eategory of investors intended to be protected." Cohen, Truth in Securi. ties Revisiled, 79 HARv. L. REv. 1340, 1370 (1967) . . . . [L]arge judgments, [are] payable in the last analysis by innocent investors, for the benefit of speculators and their lawyers. ...

SEC v. Texas Gulf Sulfur Co., 401 F.2d 833, 866-67 (2d Cir. 1968) (en banc) (Friendly, J., concurring), cert. dentied, 394 U.S. 976 (1969). 
holders is that some shareholders, at least im theory, enjoy an opportunity to benefit from the fraud. If fraud increases the market price of an issuer's shares to $\$ 50$ when their true value is $\$ 30$, then shareholders benefit because they can sell out at the higher price. But not all will. Suppose that when the price reaches $\$ 50$, one-half sell out but the remaining shareholders hold their shares. The fraud is then discovered and the price falls back to $\$ 30$. Continuing shareholders unust now bear not only that loss but also their portion of the issuer's liability to their defrauded fellow shareholders who purchased at $\$ 50$, in effect costing the contimuing group an additional $\$ 10$ per share. Telling then that this is fair because they, too, had an opportunity to sell out at a higher price is not likely to satisfy them.

Justifying subordination of shareholders' fraud claims against an issuer in bankruptcy on the related ground that shareholders have recourse against other defendants also implies a nonexistent distinction between situations in which the issuer is solvent and those in which it is insolvent. The same defendants exist regardless of whether bankruptcy proceedings have begun. If anything, bankruptcy weakens any argument for constraining the fraud plamtiffs to nonissuer defendants. The Supreme Court's adoption of a scienter standard for liability under rule $10 \mathrm{~b}-5^{149}$ narrows the class of permissible defendants to those active in the fraud. Sometimes "outsiders" such as accounting or brokerage firms bear fraud liability, but nore often the principal nonissuer defendants are members of the issuer's management. Their personal wealth frequently depends on the fortunes of the issuer. The issuer's insolvency and the expenses of the fraud and bankruptcy litigation make these defendants poor targets for successful execution of large judgments. ${ }^{150}$

2. Subordination as a Reaction to the "Revolution in Securities Regulation." As Congress and the federal courts fill in the various elements of private recovery under the securities laws, they presumably focus on the ordinary case in which the economic burden of a recovery falls on the cnlpable party. Thus, motives of penalizing the violator may share equally with the objective of defining the appropriate cir-

149. Ernst \& Ernst v. Hochfelder, 425 U.S. 185 (1976).

150. See, e.g., Paltrow, Goldblum Now in Consulting and on Parole, Wall St. J., Mar. 22, 1982, at 31, col. 3 (comment of attorney for Equity Funding's shareholders that at least five investigations conducted during the litigation failed to turn up evidence that Goldblum, Equity Funding's chairman, had significant assets other than Equity Funding stock); Notice of Proposed Voluntary Dismissal of Class Action, Jezarian v. Csapo, No. 72 Civ. 1671 (DBB) (S.D.N.Y. Mar. 3, 1982) (advising class menbers that named plaintiffs seek dismissal of action against the senior officers of Stirling Homex Corp. because none of those defendants appeared able to satisfy a judgment for a significant amount). 
cumstances for compensating the victim. To the extent that contemporary private securities law remedies go beyond a strictly compensatory objective, $\mathrm{m}$. the interests of creating an in terrorem deterrent as a supplement to governmental enforcement, ${ }^{151}$ perhaps the "bite" of these remedies should not apply to the bankrupt issuer's creditors. ${ }^{152}$ This theory comports with the general bankruptcy doctrine that claims for fines, penalties, and punitive damages should not participate on a par with other claims of general creditors. ${ }^{153}$

Subordination proponents may well have been influenced by this reasoning because of trends in securities law at that time. The Slain and Kripke article was dated May 1973; the report of the Bankruptcy Commission was released in July 1973. This comcides with the high-water mark of opportunities for recovery under the federal securites laws, especially rule $10 \mathrm{~b}-5 .{ }^{154}$ Some decisions suggested that even persons who did not actually purchase or sell a security in response to the fraud, but merely failed to take advantage of an opportunity to purchase or sell, or had indirect involvement in a purchase or sale, could recover under that rule. ${ }^{155}$ Others implied that a plaintiff did not necessarily need to prove scienter, that recovery might be available based on the defend-

151. Courts and commentators differ on whether the laws embody such a policy. Compare Globus v. Law Research Serv., Inc., 418 F.2d 1276, 1288 (2d Cir. 1969), cert. denied, 397 U.S. 913 (1970); Brief for Securities \& Exchange Commission as Intervenor, Feit v. Leasco Data Processing Equip. Corp., 332 F. Supp. 544 (E.D.N.Y. 1971) quoted in Bishop, New Problems in Indemnifying and Insuring Directors: Protection Against Liability Under the Federal Securities Laws, 1972 DUKE LJ. 1153, 1162; Shulman, Civil Liability and the Securities Act, 43 YALE L.J. 227, 253 (1933) (all of which assert that the probable primary objective of civil liability under the 1933 Act is to coinpel compliance) with Green v. Occidental Petroleum Corp., 541 F.2d 1335, 1341-46 (9th Cir. 1976) (Sneed, J., concurring) (discussing need to limit measure of 10b-5 damages to the portion of the plaintiff's loss proximately caused by the violation); Blackie v. Barrack, 524 F.2d 891, 906 (9th Cir. 1975) ("The 10b-5 action remains compensatory ... ."), cert. denied, 429 U.S. 816 (1976); Bishop, Understanding $D \& O$ Insurance Policies, Harv. Bus. Rev., Mar.-Apr. 1978, at 20, 21 (purpose of liability under federal securities laws is primarily to compensate victims rather than to punish violators); Exchange Act $\S 28(a), 15$ U.S.C. $\$ 78 b b(a)$ (1976) (no recovery under Exchange Act in excess of "actual damages" on account of the violation).

152. Consistent with the analysis in the preceding subsection of the text, this objection applies when the issuer is solvent and the shareholders bear the cost of any recovery. Because the officers and directors responsible for the fraud may be criticized by the board or the shareholders for subjecting the issuer to liability, imposing such liability on a solvent issuer may also deter the individuals actually responsible for the fraud.

153. Bankruptcy Code $\$ 726(a)(4), 11$ U.S.C. $\$ 726$ (a)(4) (Supp. V 1981).

154. Discussing private actions under the rule in 1975 , Justice Rehnquist characterized them as "a judicial oak which has grown from little more than a legislative acorn," Blue Chip Stamps v. Manor Drug Stores, 421 U.S. 723, 737 (1975), which "presents a danger of vexatiousness different in degree and kind from that which accompanies litigation in general." $/ d$ at 739.

155. See Manor Drug Stores v. Blue Chip Stamps, 492 F.2d 136 (9th Cir. 1973), rev'd, 421 U.S. 723 (1975); Eason v. General Motors Acceptance Corp., 490 F.2d 654 (7th Cir. 1973), cert. denied, 416 U.S. 960 (1974). 
ant's negligence. ${ }^{156}$ Finally, some decisions raised the possibility that rule $10 \mathrm{~b}-5$ could remedy breaches of fiduciary duty by corporate management if these breaches involved the purchase or sale of a security. ${ }^{157}$

It was also suggested at about this time that the private offering exemption from registration under the 1933 Act $^{158}$ would apply only when the offerees possessed insider status with respect to the issuer. ${ }^{159}$ Thus, anyone not possessing that status who purchased securities im a nonregistered offering would have an automatic right to rescind under section 12(1) of the 1933 Act unless another exemption happened to apply. ${ }^{160}$ Finally, the SEC generated considerable concern about the potential breadth of hability under the federal securities laws by suggesting in National Student Marketing that an attorney, by failing to disclose that his chent had violated the securities laws, became hable for the violation himself. ${ }^{161}$ In 1973, the ABA's Section of Corpora-

156. See Hochfelder v. Ernst \& Ernst, 503 F.2d 1100, 1114-15 (7th Cir. 1974), rev'd, 425 U.S. 185 (1976); White v. Abrams, 495 F.2d 724, 734-36 (9th Cir. 1974); City Nat'l Bank v. Vanderboom, 422 F.2d 221, 229-30 (8th Cir.), cert. denied, 399 U.S. 905 (1970); see also Ellis v. Carter, 291 F.2d 270, 274 (9th Cir. 1961).

157. See Bailes v. Colonial Press, Inc., 444 F.2d 1241, 1245-46 (5th Cir. 1971); Rekant v. Desser, 425 F.2d 872, 880, 882 (5th Cir. 1970); Schoenbaum v. Firstbrook, 405 F.2d 215 (2d Cir. 1968) (en banc), cert. denied, 395 U.S. 906 (1969); Pappas v. Moss, 393 F.2d 865, 869-70 (3d Cir. 1968); Dasho v. Susquehanna Corp., 380 F.2d 262, 269-70 (concurring opinion) (7th Cir. 1967); see also Hooper v. Mountain States Secs. Corp., 282 F.2d 195, 202-03 (5th Cir. 1960), cert. denied, 365 U.S. 814 (1961); and two later cases, Green v. Santa Fe Indus., 533 F.2d 1283, 1291 (2d Cir. 1976), rev'd, 430 U.S. 462 (1977); Marshel v. AFW Fabric Corp., 533 F.2d 1277, 1281 (2d Cir.), vacated, 429 U.S. 881 (1976).

158. Securities Act $\$ 4(2), 15$ U.S.C. $\$ 77 d(2)$ (1976).

159. These suggestions stemmed largely from two Fifth Circuit decisions. In Hill York Corp. v. American Int'l Franchises, Inc., 448 F.2d 680 (5th Cir. 1971), the court stated that limiting the offerees to sophisticated lawyers and busimessnen would not by itself establish an exenuption; the offerees must in addition possess the type of information that registration would have provided. Id. at 690. Then, in SEC v. Continental Tobacco Co., 463 F.2d 137 (5th Cir. 1972), the court stated that mere disclosure of the same type of information as is contained in a registration statement did not necessarily render the offering exempt, and implied that the offerees must have a "relationship" to the issuer which allows them independent access to such information. Id. at 15862. This opinion, coupled with language in the SEC's brief in the case, caused serious concern within the securities bar about the continued availability of the exemption for outside financing.

160. Professors Slain and Kripke invoked this concern over the expanded availability of section 12(1) rescission in making their case for subordination. To denionstrate the "inequity" of allowing rescinding shareholders to participate on a par with general creditors, they presented a hypothetical derived from yet another Fifth Circuit private offering case, Henderson v. Hayden, Stone Inc., 461 F.2d 1069 (5th Cir. 1972), involving a sale of securities to an experienced investor who managed a personal investment portfolio valued at several million dollars. The hypothetical raised the possibility that a sophisticated investor with full access to registration information could rescind and share with contract creditors siniply because the issuer could not carry the burden of proof that each of the other offerees possessed comparable sophistication and access. Slain \& Kripke, supra note 44, at 263-65.

161. Complaint at I 48, SEC v. National Student Mktg. Corp., [1971-1972 Transfer Binder] Fed. Sec. L. Rep. (CCH) I 93,360 (D.D.C., conplaint filed Feb. 3, 1972). 
tion, Banking and Busmess Law titled these and other developments the "Revolution in Securities Regulation." 162 Although over the next few years the United States Supreme Court and the SEC would reverse many of the trends that underlay this description, ${ }^{163}$ these developments were unforeseen when Professors Slam and Kripke and the Bankruptcy Commission began to advocate the subordmation doctrine.

Throughout this period, and continuing to the present, an inportant aspect of the expansion of federal securities law liability to attain regulatory goals has been a broadening of the sorts of statements and representations that are considered actionable. The various antifraud provisions contained in the laws prohibit not only outright falsehoods but also statements that may be literally true but are nontheless misleading. ${ }^{164}$ The SEC and the courts have employed these provisions to control situations that fall short of "fraud" im the more traditional and colorful sense conjured up by the promoter's liability cases at the turn of the century. For example, one court held that a registration statement and prospectus created section 11 liability by failing to describe in clear terms the amount and the implications of a proposed takeovertarget insurance company's excess reserves. 165 Other courts held disclosure materials misleading because important facts, although discernible from a reading of the materials as a whole, were in effect "buried" when they sliould have been "highlighted" or given "similar emphasis" to a related statement. ${ }^{166}$ These holdings reveal a willingness by courts

162. This was the title of an ABA-sponsored National Institute in October 1973, the proceedings of which are published in 29 Bus. LAw., March 1974 (Special Issue). Among the papers were "Are There Limits to Rule 10b-5?", "The Securities Class Action for Damages Comes of Age (1966-1974)", and "Federal Regulation of Internal Corporate Affairs." Professor Kripke concluded the proceedings and cited the SEC's position that securities law claims should be entitled to parity in bankruptcy as an example of its "hubris" and "tunnel vision." Id at 185.

163. See Transamerica Mortgage Advisors, Inc. v. Lewis, 444 U.S. 11 (1979); Touche Ross \& Co. v. Redington, 442 U.S. 560 (1979) (both limiting the power of federal courts to fashion inplied private rights of action); Santa Fe Indus., Inc. v. Green, 430 U.S. 462 (1977); Emst \& Ernst v. Hochfelder, 425 U.S. 185 (1976); Blue Chip Stamps v. Manor Drug Stores, 421 U.S. 723 (1975) (all limiting private actions under rule 10b-5); Securities Act \& 4(6), 15 U.S.C. \& 77d(6) (Supp. V 1981) (enacted Oct. 21, 1980) and Securities Act Regulation D, 17 C.F.R. $\$ \$ 230.501$-.506 (1982) (expanding the limited offering exemptions).

164. This language comes froin Securities Act $\& 17(a)(2), 15$ U.S.C. $\$ 77 q(a)(2)(1976)$, but the other antifraud provisions are worded comparably. The provisions prohibit "any untrue stateunent of a material fact" and "any omission to state a unaterial fact necessary in order to make the statements made, in light of the circumstances in which they were unade, not misleading." I5 U.S.C. \& 77q(a)(2) (1976).

165. Feit v. Leasco Data Processing Equip. Corp., 332 F. Supp. 544, 564-66 (E.D.N.Y. 1971) (criticizing use of "turgid prose to enshroud the occasional critical revelation in a morass of dull, and-to all but the sophisticated-useless financial and historical data").

166. Mills v. Electric Auto-Lite Co., 403 F.2d 429, $432-34$ (7th Cir. 1968), rev'd on the issue of causation, 396 U.S. 375 (1970); Gould v. American Hawaiian S.S. Co., 331 F. Supp. 981, 994-96 (D. Del. 1971), rev'd on other grounds, 535 F.2d 761 (3d Cir. 1976); Kohn v. American Metal 
to employ the antifraud provisions to improve the overall quality of disclosure as well as to remedy outright fraud.

Consider also the possible consequences of management misconduct uncovered in bankruptcy. Suppose that the bankrupt, a publicly. held corporation, has assets of $\$ 100$ million, contract creditor claims of $\$ 150$ million, and had sold shares to the public in a registered offering at an aggregate price of $\$ 12$ million. ${ }^{167}$ Creditors' lawyers discover that the bankrupt's president and principal shareholder had, for several years before the public offering, caused the bankrupt to advance funds to his wholly-owned corporation while successfully concealing this activity from the bankrupt's directors. Although lie repaid most of the advances within a few weeks and the outstanding amount never exceeded $\$ 1.5$ million dollars, at the time of the bankruptcy the president owed $\$ 1$ million in advances. General bankruptcy law would allow the bankruptcy estate to recover the advances, together with reasonable interest, for the benefit of the general creditors. The public shareholders, however, may argue that the president's concealment of the advances defrauded them, and demand repayment of their entire $\$ 12$ million investment in the bankrupt issuer, an argument predicated on expansive interpretations of the disclosure requirements of the securities laws. ${ }^{168}$

Climax, Inc., 322 F. Supp. 1331 (E.D. Pa. 1971), modified, 458 F.2d 255 (3d Cir.), cert. denied, 409 U.S. 874 (1972); cf. Gerstle v. Gamble-Skogmo, Inc., 478 F.2d 1281, 1297 (2d Cir. 1973) ("While 'corporations are not required to address their stockholders as if they were children in kindergarten.' Richland v. Crandall, 262 F. Supp. 538, 554 (S.D.N.Y. 1967), it is not sufficient that overtones might have been picked up by the sensitive antennae of investment analysts."); Robinson v. Penn Central Co., 336 F. Supp. 655, 657 (E.D. Pa. 1971)(inessage in proxy statement "too well encoded to be meaningful"). In commenting on the Seventh Circuit's conclusion in Mills that a proxy statement's failure to point out that the majority shareholder had selected and elected the directors of its subsidiary was a material omission, 403 F.2d at 432-34, a popular securities casebook notes: "Who any shareholder with enough education to sign a proxy card would assume had selected the directors elected by the majority shareholder, the court didn't suggest." R. JENNINGS \& H. MARSH, SECURITIES REgULATION 929 (4th ed. 1977). Co-editor Marsh, it may be worth recalling, was chairman of the Bankruptcy Commission and the principal proponent of the subordination rule. See supra note 44 and infra note 169.

167. The facts of this hypothetical approximate the situation that gave rise to In re Franchard Corp., 42 S.E.C. 163 (1964) and Fox v. Glickınan Corp., 253 F. Supp. 1005 (S.D.N.Y. 1966).

168. The failure to disclose the advances could be actionable under two theories. Paragraph (e) of Item 402 of Regulation S-K (codified at 17 C.F.R. \$ 229.402(e) (1982)), requires disclosure of the advances, a requirement incorporated by reference in several SEC forms. For an illustration of a court's willingness to employ the item requirements of SEC disclosure forms to reach matters of misconduct, see United States v. Fields, 592 F.2d 638 (2d Cir. 1978), cert. denied, 442 U.S. 917 (1979). Or the disclosure could be required to make other of the issuer's statements not misleading. See Maldonado v. Flynn, 597 F.2d 789, 796-98 (2d Cir. 1979); SEC v. Jos. Schlitz Brewing Co., 452 F. Supp. 824, 829 (E.D. Wis. 1978); Rafal v. Geneen, [1972-1973 Transfer Binder] Fed. Sec. L. Rep. (CCH) 993,505 (E.D. Pa. May 8, 1972); Cooke v. Teleprompter Corp., 334 F. Supp. 467 (S.D.N.Y. 1971). Despite the relatively small dollar amounts involved in the hypothetical-1.5\% of assets-the activity might nevertheless be "material" because it bears on 
Ironically, creditors could be worse off for having discovered the president's self-dealing if the resulting securities law claims against the bankrupt receive parity with their claims.

Concern over such expanding securities law liability may have influenced the proponents of subordination. ${ }^{169}$ The subordination doctrine, lowever, provides a poor solution to these concerns because it affords no basis for distinguishing the case involving a "technical" or "creative" theory of liability from the one involving outright fraud or falsehoods. Furthermore, the broadened interpretations of what is "material" and "misleading" have typically emerged from SEC enforcement actions or froin private derivative actions or suits for equitable relief based on statements in the proxy voting context, rather than from actions for damages based on statements made in the imvestment context. Courts willing to find a statement actionable in the proxy voting context, in the interest of improved corporate governance or quality of disclosure, might not be so imclined in the investment context. ${ }^{170}$ More importantly, proof that a statement is materially misleading does not mean that a plaintiff can prove that it damaged him. ${ }^{171}$ Thus, fears

the integrity of management. See In re Franchard Corp., 42 S.E.C. 163, 169-75 (1964); SEC v. Jos. Schlitz Brewing Co., 452 F. Supp.824, 829-30 (E.D. Wis. 1978); SEC v. Kalvex, Inc., 425 F. Supp. 310,315 (S.D.N.Y. 1975); REPORT OF THE S.E.C. ON QUESTIONABLE AND ILLEGAL CORPOrate Payments and Practices, 94th Cong., 2d Sess. 15 (1976).

169. The deliberations of the Bankruptcy Commission provide evidence of this influence. At one point in the discussion, Chairman Marsh "empliasized that the number of stockholders' claims [in bankruptcy] might greatly increase because the substantive law authorizing them was continuing to expand and because the Commission members had decided to make all claims provable in liquidation." See supra note 139. In response, Congressman Wiggins, another member of the Commission, "questioned the merit of juggling the Bankruptcy Act to accomodate what is said by some to be bad law. Minutes of the Bankruptcy Commission, Feb. 22-24, 1973, at 37.

170. For recognitions that information material in the proxy voting setting may not be material in the investunent setting, see Ferrara, Starr \& Stemberg, Disclosure of Information Bearing on Management Integrity and Competency, 76 Nw. U.L. REv. 555, 559-60, $607-09$ (1981); Address by Ray Garrett, Jr., entitled "The Uses of Disclosure," at 6, National Investor Relations Institute (Sept. 30, 1975) (on file at the library of the SEC, Washington, D.C.); Sommer, The Slippery Slope of Materiality (pt. 1), N.Y.L.J., Dec. 15, 1975, at I, col. 2; cf. REPORT OF THE S.E.C. ON QUESTIONable and Illegal Corporate Payments and Practices, 94th Cong., 2d Sess. 22 (1976) ("In attempting to determine whether a specific fact is material there is no litinus paper lest. Each case normally presents unique combinations of facts, and the consideration whether particular information should be disclosed necessarily depends on the context in which the question arises.")

171. Many of the cases discussed in this section involving monetary relief that resulted in a final judgment produced comparatively little for the plaintiffs. In Feit v. Leasco Data Processing Equip. Corp., 332 F. Supp. 544, 584-88 (E.D.N.Y. 1971), damages were reduced to rcflect the decline in the stock market generally and recovery was limited to those persons who both accepted the exchange offer and then sold the stock they received during narrow interval in mid-1969 (about one year after the exchange); in Gould v. American Hawaiian S.S. Co., 535 F.2d 761, 783. 84. (3d Cir. 1972), damages were set at $\$ 1.79$ per share on shares worth $\$ 41.75$ at the time of the merger, and in Mills v. Electric Auto-Lite Co., 552 F.2d 1239 (7th Cir.), cert. denied, 434 U.S. 922 (1977), the court ultimately held that the plaintiffs had proven no damages. 
motivating subordination may far exceed any actual chance of a fraud recovery.

These concerns suggest that the better way to ensure that creditors do not bear the costs of any deterrence is to require a strict causal nexus between the securities violation in question and the anount of the securityholder's claim entitled to parity in bankruptcy. The out-ofpocket measure of damages suggested in the last section as the answer to the best-of-both-worlds problein embodies such a causation requirement and assures that only misstatements that are material in a traditional, economic sense produce recovery. Only that kind of misstatement can cause an out-of-pocket loss.

\section{Allocating the Fraud Loss Between Debt and Equity HOLDERS}

Part II demonstrated that the arguments traditionally advanced in support of subordination do not justify discriminating against securities law claims by contemporary shareholders to the extent those shareholders seek only out-of-pocket damages. This part addresses the problem from a different perspective: who should bear the losses in investinent value caused by securities law violations, or, as Slain and Kripke would put it, the risk of illegality in securities issuance? ${ }^{172}$ Using a numerical example, this part concludes that permitting securities law claimants to participate on a par with general creditors to the extent of out-of-pocket fraud losses produces the fairest allocation of the overall fraud loss among the various claimants of the bankrupt.

\section{A. The Basic Industries Corporation Example-Background.}

Assume that Basic Industries Corporation (BIC) is a firm manufacturing a "fad" product with a cyclical demand. For simplicity assume that each investor purchases BIC securities at the beginning of a cycle and that each investor intends to hold his shares for one cycle. Also, each investor expects that, at the end of the cycle, BIC will liquidate, repay its debt, and distribute its remaining assets to its shareholders. For simplicity in this example, these investors are homogeneous. On the basis of BIC's publicly available financial reports, they have uniform expectations about its performance; they are risk neutral; 173 and they require a $20 \%$ expected return on their investments in BIC

172. Slain \& Kripke, supra note 44 , at $286,288$.

173. "Risk" is used here in the sense employed in contemporary financial theory to mean volatility of returns. Risk neutral investors will treat equally two securities with an expected return of $20 \%$, even though one will yield $20 \%$ as an absolute certainty and the second has a $50 \%$ probability of yielding $10 \%$ and a $50 \%$ probability of yielding $30 \%$. 
securities for the period. ${ }^{174}$

Necessarily, these prospective investors can only estimate the future value of BIC at the end of its life using available information and assumptions about its performance, the industry, and the economy as a whole during the period. To quantify this valuation process, assuine that the investors make four alternative predictions about these conditions. Under the most optimistic assumption, the investors project that BIC will have a total value of $\$ 48$ million at the end of the cycle, and they estimate that this assuinption has a $20 \%$ probability of coming true. Their second prediction, shghtly less optimistic, projects a final value of $\$ 36$ million with a $30 \%$ chance of occurrence. The third prediction sets BIC's final value at $\$ 24$ million, with a probability of occurrence of $30 \%$. The fourth prediction assumes a $\$ 12$ million final value and a $20 \%$ probability.

\section{TABle I: INVestor Value Assumptions}

$$
\text { (millions of dollars) }
$$

\begin{tabular}{|c|c|c|c|}
\hline Outcome & Prediction & $\begin{array}{l}\text { Assumed } \\
\text { Probability }\end{array}$ & Value of Firm at its End \\
\hline \#1 & Very Optimistic & 0.2 & $\$ 48.0$ \\
\hline \#2 & Mildly Optimistic & 0.3 & $\$ 36.0$ \\
\hline \#3 & Mildly Pessimistic & 0.3 & $\$ 24.0$ \\
\hline$\# 4$ & Very Pessimistic & 0.2 & $\$ 12.0$ \\
\hline
\end{tabular}

This estimation process, illustrated in Table I, yields an "expected" final value, based on the published financial data and the alternative predictions, of $\$ 30$ million. ${ }^{175}$ Thus BIC's present value as the period begins is $\$ 25$ million $-\$ 30$ million discounted at the $20 \%$ rate of return the investors desire.

\section{B. BIC's Equity and Debt Values.}

Given this background, suppose that at the beginning of the manufacturing period BIC's original owners decide to refinance the entire

174. None of these assumptions, made solely for the purpose of facilitating presentation and analysis, should affect the substantive legal conclusions that follow from the example. For examples of similar models used to depict the allocation of the firm's value between different clesses of its securityholders, see W. KLEIN, Business OroANIzATION AND FinaNCE, ch. 4 passim (1980); Miller, The Wealth Transfers of Bankruptcy: Some Illustrative Examples, 41 LAw \& CoNTEMP. - PROBS., Autumn 1977, at 39; see also infra note 177.

175. The term "expected value," used in its conventional statistical sense, designates the central tendency of a random variable, here the end-of-period value of the firm. Put simply, it is the weighted average of the four alternative projected values, with the weights equal to the probability of cocurrence of each: $(\$ 48$ million $\times .2)+(\$ 36$ million $\times .3)+(\$ 24$ million $\times .3)+(\$ 12$ million $X .2)=\$ 30$ million. 
firm by selling new securities to the public. In public offerings they sell $\$ 15$ million in principal amount of non-interest-bearing debentures, maturing at the end of the period, and one million shares of common stock. From the purchasing investor's viewpoint, based on B1C's published information, the expected value of the debentures at the end of the period is $\$ 14.4$ million, rather than their face value of $\$ 15$ million, because BIC may well default if the most pessimistic prediction comes true. Therefore, the debentures have a present value of $\$ 12$ million. The resulting expected value of the equity is $\$ 15.6$ million, or $\$ 15.60$ per share, with a present value of $\$ 13$ million, or $\$ 13$ per share.

\section{Table II: Apparent Value of BIC Securities}

(millions of dollars)

\begin{tabular}{|c|c|c|c|c|c|}
\hline Outcome & Prediction & Probability & $\begin{array}{l}\text { Firm } \\
\text { End } \\
\text { Value }\end{array}$ & $\begin{array}{l}\text { Debt } \\
\text { End } \\
\text { Value }\end{array}$ & $\begin{array}{c}\text { Equity } \\
\text { End } \\
\text { Value } \\
\end{array}$ \\
\hline $\begin{array}{l}\# 1 \\
\# 2 \\
\# 3 \\
\# 4\end{array}$ & $\begin{array}{l}\text { Very Optimistic } \\
\text { Mildly Optimistic } \\
\text { Mildly Pessimistic } \\
\text { Very Pessimistic }\end{array}$ & $\begin{array}{l}0.2 \\
0.3 \\
0.3 \\
0.2\end{array}$ & $\begin{array}{l}\$ 48.0 \\
\$ 36.0 \\
\$ 24.0 \\
\$ 12.0 \\
\end{array}$ & $\begin{array}{l}\$ 15.0 \\
\$ 15.0 \\
\$ 15.0 \\
\$ 12.0 \\
\end{array}$ & $\begin{array}{l}\$ 33.0 \\
\$ 21.0 \\
\$ 9.0 \\
\text { Zero } \\
\end{array}$ \\
\hline $\begin{array}{l}\text { Probabilit } \\
\text { of all Ass } \\
\text { Present V }\end{array}$ & $\begin{array}{l}\text { yeighted Average } \\
\text { imed Outcomes... } \\
\text { alue of Assumed Av }\end{array}$ & & $\begin{array}{l}\$ 30.0 \\
\$ 25.0\end{array}$ & $\begin{array}{l}\$ 14.4 \\
\$ 12.0\end{array}$ & $\begin{array}{l}\$ 15.6 \\
\$ 13.0\end{array}$ \\
\hline
\end{tabular}

Now assume that BIC's financial statements used in the public offering contain several misrepresentations. If public investors liad known the true situation, they would have revised their assessment of BIC's end value because their inore pessimistic predictions would have liad a greater probability of being accurate. This revised assessment of the true state of the firm is depicted in Table III. Like Alphonse in the Diversified Mining liypothetical, BIC's debtholders and equityholders have actually acquired interests in a very different firm from the one they thought they were acquiring. Because BIC's real present value was only $\$ 18$ million, absent the fraud, presumably the investors would have paid only that amount for its debentures and shares. By paying $\$ 25$ million instead, the investors incurred an immediate loss im investment value of $\$ 7$ million-a $\$ 7$ million "expected fraud loss." Note that the existence of this expected loss does not mean that the investors will necessarily suffer an actual loss on their investment. As the last column of Table III indicates, there is a $20 \%$ chance the firm will flourishOutcomes \#1 and \#2-and achieve a final worth of either $\$ 48$ million or $\$ 36$ million at the end of the period, in which case the loolders of the debentures would realize an actual return of $25 \%$, and the equi- 
tyholders a return of either $154 \%$ or $62 \%$. As Table III indicates, despite this possible outcome, both classes of investors still incurred an immediate loss of value when they purchased their securities because the fraud caused them, like Alphonse, to overpay for the investment opportumities they actually received.

\section{Table III: Comparison of Assumed BIC Values and True BIC VALUES}

(millions of dollars)

\begin{tabular}{|c|c|c|c|c|c|c|}
\hline Outcome & Prediction & $\begin{array}{l}\text { (Fraud) } \\
\text { Assumed } \\
\text { Probability }\end{array}$ & $\begin{array}{l}\text { End } \\
\text { Value }\end{array}$ & $\begin{array}{l}\text { End } \\
\text { Debt } \\
\text { Value }\end{array}$ & $\begin{array}{l}\text { End } \\
\text { Equity } \\
\text { Value }\end{array}$ & $\begin{array}{l}\text { (Fraud Disclosed) } \\
\text { True } \\
\text { Probability }\end{array}$ \\
\hline $\begin{array}{l}\# 1 \\
\# 2 \\
\# 3\end{array}$ & $\begin{array}{l}\text { Very Optimistic } \\
\text { Mildly Optimistic } \\
\text { Mildly Pessimistic } \\
\text { Very Pessimistic }\end{array}$ & $\begin{array}{l}0.2 \\
0.3 \\
0.3 \\
0.2\end{array}$ & $\begin{array}{l}\$ 48.0 \\
\$ 36.0 \\
\$ 24.0 \\
\$ 12.0 \\
\end{array}$ & $\begin{array}{l}\$ 15.0 \\
\$ 15.0 \\
\$ 15.0 \\
\$ 12.0 \\
\end{array}$ & $\begin{array}{l}\$ 33.0 \\
\$ 21.0 \\
\$ 9.0 \\
\text { Zero } \\
\end{array}$ & $\begin{array}{l}0.1 \\
0.1 \\
0.3 \\
0.5\end{array}$ \\
\hline \multicolumn{3}{|c|}{$\begin{array}{l}\text { Assumed Probability-Weighted } \\
\text { Average Outcomes } \ldots \ldots \ldots \ldots \ldots \ldots \ldots \\
\text { Less True Probability-Weighted } \\
\text { Average Outcomes } \ldots \ldots \ldots \ldots \ldots \ldots \ldots\end{array}$} & $\$ 30.0$ & $\$ 14.4$ & $\$ 15.6$ & \\
\hline \multicolumn{3}{|c|}{$\begin{array}{l}\text { Expected Fraud Loss } \ldots \ldots \ldots \ldots \ldots \ldots \\
\text { Present Value of Fraud Loss } \ldots \ldots \ldots \ldots \ldots \\
\text { BIC's True Present Values ................... }\end{array}$} & $\begin{array}{l}\$ 8.4 \\
\$ 7.0 \\
\$ 18.0\end{array}$ & $\begin{array}{lc}\$ & .9 \\
\$ & .75 \\
\$ 11.25\end{array}$ & $\begin{array}{l}\text { \$ } 7.5 \\
\text { \$ } 6.25 \\
\text { \$ } 6.75\end{array}$ & \\
\hline
\end{tabular}

\section{Allocation of the Expected Fraud Loss.}

1. No Securities Remedies. If the investors have no securities law remedies, the result is the allocation depicted in the next-to-last line of Table III. Clearly, both debtholders and equityholders suffer as a result of the fraud. Under the revised probabilities, a 50\% risk of insolvency actually exists, in which case the debtholders would receive only $\$ 12$ million on their claims, equivalent to $\$ .80$ on the dollar; thus the end-of-period expected value of these securities falls from $\$ 14.4$ million to $\$ 13.5$ million. ${ }^{176}$ The effect on the equity is much harsher: with only a $20 \%$ chance that the firm will prosper, and a $50 \%$ chance that it will fail and leave the equityholders with nothing, the true probabilityweighted future value of the equity drops froin $\$ 15.6$ million to $\$ 8 . I$ million. ${ }^{177}$

176. $(\$ 15$ million $\times .1)+(\$ 15$ million $\times . \mathrm{I})+(\$ 15$ million $\times .3)+(\$ 12$ million $\times .5)=\$ 13.5$ million.

177. To increase the illustrative value of these conclusions, an attempt was made to assign realistic numerical values to the parameters of the hypothetical. The debt-equity ratio is approximately one-to-one, and the net effect of the fraud reduces the expected value of the firm by $28 \%$. Two numerical values, however, have been chosen to highlight the differences between parity and subordination. First, the default risk on the BIC debentures is $4 \%$ (a $20 \%$ risk of default multipled by a $20 \%$ loss upon default). Second, BIC faces a $40 \%$ probability that the final value of the entire firm will vary by $60 \%$ from its expected value. Both of these probabilities seem quite high. For 
2. Securities Remedies Funded by Non-Issuers. Assume now that the investors have securities law remedies, and that these remedies lie against defendants other than the issuer-against BIC's promoters, for example - so that adequate assets to fund these remedies will exist no matter what the true end-of-period value of BIC. A deceit remedy, as noted earher, awards investors damages equal to the difference between the price paid for the security and the value the investor actually received. ${ }^{178}$ For purchasers of BIC stock this means total damages of $\$ 6.25$ per share measured as of the time of purchase or $\$ 7.50$ per share at the end of the period. ${ }^{179}$ In effect, the securities laws give them, im heu of the more attractive security they thought they bought, a package consisting of one share of the stock as it actually is and the right to a check for $\$ 7.50$ at the end of the period. ${ }^{180}$ Although such a remedy allows the shareholders to receive something even if the company fails, it does not allow them to evade a busmess risk they voluntarily assumed, which is the best-of-both-worlds concern. ${ }^{181}$ The shareholders consented to receive a zero return if BIC fails as a part of a package

example, in terms of a realistic measure of an expected default risk on debt, the annual rate of loan-loss projections for the country's largest banks in the second quarter of 1982 ranged between $0.62 \%$ and $0.23 \%$ of total loans. This excludes Continental lllinois Corp., which experienced an unusually high $3.03 \%$ loss as a result of loans purchased through the failed Penn Square Bank in Oklahoma. Bennett, Continental Illinois Challenge, N.Y. Times, Aug. 2, 1982, at DI, col. 3. Generally, the selection of these highlighting parameters should lave no impact on the substantive analysis; in the few instances in which it does, there has been an attempt to note this impact in the discussion.

178. This figure corresponds to the present value of the fraud loss shown on the next to last line of Table Ill; it reflects an out-of-pocket measure of deceit damages. The distinction between an out-of-pocket and benefit-of-the-bargain measure, see supra note 138, has no relevance in the BIC problem because of the assumption that BIC investors paid prices equal to the values of the securities as represented. Cf. supra note 141.

179. This end-of-period figure of $\$ 7.50$ per share equals basic deceit damages of $\$ 6.25$ per share plus prejudgment interest at the rate of $20 \%$. Securities law claims generally allow such prejudgment interest. Some statutory remedies provide for it directly. Securities Act $\& 12,15$ U.S.C. \& 77(1) (1976); Uniform Securities Act \& 410(a) (1958). For other remedies, such as the implied private right of action under rule 10b-5, cours have treated the award of prejudgment interest as discretionary. See Ross v. Licht, 263 F. Supp. 395, 411 (S.D.N.Y. 1967); Speed v. Transamerica Corp., 135 F. Supp. 176, 194-201 (D. Del. 1955), affd, 235 F.2d 369 (3d Cir. 1956); see also Federal Securities CODE § I723(c) comment (1978). For indications that a suit for rescission or a tort action for deceit allows prejudgment interest see RESTATEMENT OF RESTITUTION \& 156 (1937); RESTATEMENT (SECOND) OF TORTS \& 913(1)(b) (1977).

180. For ease of computation, the text and notes that follow assume that the equityholders assert their securities law claims at the end of the period and that they may claim prejudgment interest, so that end-of-period deceit damages amount to $\$ 7.50$ per share and a restitutional recovery umounts to $\$ 15.60$ per share. If the shareholders cannot receive prejudgment interest, either as a result of the substantive law creating the claim or the Bankruptcy Code, see 11 U.S.C. $\$ 726(a)(5)$ (Supp. V 1981), then the equityholders will bear an even greater portion of the total fraud loss vis-a-vis contract creditors than the amonnt computed in the text.

181. See supra text accompanying notes $122-44$. 
presenting a $20 \%$ risk of insolvency and a $20 \%$ probability of returning $154 \%$ on their investunent; the true BIC investinent opportunities and risks are quite different. The law cannot exactly replicate the investment opportunities and risks that these shareholders thought they had consented to, but the deceit remedy does the next best thing by creating a substitute set of opportunities and risks-the package consisting of stock and a check for $\$ 7.50$ of comparable value. ${ }^{182}$

182. The deceit remedy effectively creates a new set of four alternative outcomes and associated probabilities for the end-of-period value of the equity. The alternative outcomes are the values of the equity under Outcomes \#1 through \#4 in Table III, increased in each case by the $\$ 7.5$ million aggregate deceit remedy, and the associated probabilities are the true BIC ones as set out in the last column of Table III. The result is a package with the same expected value- $\$ 15.60$ per share-as the BIC stock investors, under the influence of the fraud, thought they bought.

(per share basis)

The Stock Investors

Thought They Bought

\begin{tabular}{|c|c|c|}
\hline Outcome & $\begin{array}{l}\text { Assumed } \\
\text { Probability }\end{array}$ & $\begin{array}{l}\text { Expected } \\
\text { End Value } \\
\text { of Equity }\end{array}$ \\
\hline \multirow[t]{2}{*}{$\begin{array}{l}\# 1 \\
\# 2 \\
\# 3 \\
\# 4\end{array}$} & $\begin{array}{l}.2 \\
.3 \\
.3 \\
.2\end{array}$ & $\begin{array}{l}\$ 33.00 \\
\$ 21.00 \\
\$ 9.00 \\
\$-0\end{array}$ \\
\hline & 1.0 & \\
\hline
\end{tabular}

Probability-Weighted

Average End Value

\section{True BIC Stock}

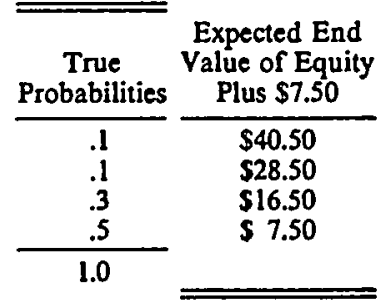

.... $\quad \$ 15.60$

This analysis assumes that the investor can recover damages with a deceit theory even under Outcomes \#1 and \#2 if he has a gain on his BlC shares. The logic of out-of-pocket damages, which measure the plaintiffs loss as of the time of purchase, clearly allows such recovery. See Jacobs, The Measure of Damages in Rule 10b-S Cases, 65 GEo. L.J. 1093, 1156 n.339, 1158 (1977). Courts might not often make such awards, however, because shareholders lolding appreciated stock are less likely to bring suit, and the fraud may simply go unnoticed. The difficulties in isolating and proving the damage caused by the fraud, coupled with the fact that the plaintiffs have benefitted from the transaction being challenged, will also pose significant obstacles to recovery. See, eg., Harris v. American Inv. Co., 523 F.2d 220, 225-27 (8th Cir. 1975), cert. denied, 423 U.S. 1054 (1976); Bonime v. Doyle, 416 F. Supp. 1372, 1384-86 (S.D.N.Y. 1976), affd mem., 556 F.2d 554, 555 (2d Cir. 1977) (cases look to price of security after fraud revealed as evidence of its value at time of purchase); see also FEDERAL SECuRITIES CODE \& 1708(b)(1) (1978); RestaTEMENT (SECOND) OF TORTS \& 549 coniment (c), lst I (1976); I F. HARPER \& F. JAMES, supra note 128, at 600.03 (cases discussed). When plaintiffs seek relief under the federal securities laws, some courts may also take the position that a plaintiff incurring no monetary loss cannot receive relief. See Morse v. Peat, Marwick, Mitchell \& Co. (In re Investors Funding Corp. Securities Litigation), 523 F. Supp. 563, 566-68 (S.D.N.Y. 1980); Abrahamson v. Fleshner, 392 F. Supp. 740, $746-$ 49 (S.D.N.Y. 1975), rev'd in part on other grounds, 568 F.2d 862, 868-69 n.9 (2d Cir. 1977), cert. denied, 436 U.S. 905,913 (1978).

If, however, shareholders uncover BIC's fraud before the end of its period, so that share prices fall from $\$ 13.00$ to $\$ 6.75$ (see Table III), and then rise to $\$ 33.00$ or $\$ 21.00$ as Outcoune \#1 or \#2 emerges, a shareholder who retained his shares throughout the period might recover notwithstanding his gain. See Harris v. American Inv. Co., 523 F.2d 220, $227-28$ (8th Cir. 1975) (rule 10b5 out-of-pocket damages allowed because plaintiff made a "second investunent decision" to hold 
As the Diversified Mining problein illustrated, rescission works differently. It permits investors, at the end of the period, to elect either to retain BIC shares or receive their purchase price- $\$ 15.60$ per share including prejudgment interest. Naturally investors will choose the alternative more valuable under the particular outcome: they will choose to retain their stock if Outcoines \#1 or \#2 occur, but rescind if Outcomes \#3 or \#4 occur. This option actually increases the expected value of investors' stock holdings from the $\$ 15.60$ per share represented by the stock above to $\$ 17.88$, the expected value of the stock-plus-rescission package. ${ }^{183}$ This $\$ 2.28$ increase represents, in effect, a dollarand-cents quantification of the best-of-both-worlds benefit the investor derives from being able to employ rescission to renounce the business risk inherent in his BIC shares. ${ }^{184}$

3. Securities Remedies in the Real World-Subordination. Now eliminate the somewhat unrealistic assumption that non-issuer defendants' assets will fully fund any securities law remedies. Examine instead how these remedies, coupled with the subordimation or parity rules, allocate the total fraud-caused investment loss between debt and equity investors. Under the subordination rule, the debtholders are entitled to receive their full contract claims of $\$ 15$ million before any assets may be distributed to securities law claimants. Thus, in the example, no matter what the remedy, the true expected and present value of the

shares after fraud; the performance of the shares after this decision had no bearing on the measure of his damages), cert. denied, 423 U.S. 1054 (1976); accord, Sirota v. Solitron Devices, Inc., 673 F.2d 566, 577 (2d Cir.), cert. denied, 103 S.Ct. 86 (1982); Cant v. A.G. Becker \& Co., 379 F. Supp. 972, 975 (N.D. Ill. 1974). But see Note, Reaping the "Fruits of an Unrealized Speculation": May a Buyer Who Profis from a Transaction also Recover Damages Under Rule 10b-5, 33 RUTGERS L. REV. 973 (1981); Securities Act $\$ 811($ e), 12, 15 U.S.C. $\$ 877 k(e), 771$ (1976) (express remedies under the Securities Act would restrict a plaintiff to his monetary loss).

If a plaintiff's deceit-type damages include only monetary loss because of the authorities discussed in this footnote, the expected value of the stock-plus-damages package decreases from $\$ 15.60$ per share to $\$ 13.83$ per share.

183. This expected value was computed on the following set of investor's options to retain his shares when profitable and rescind when not:

\begin{tabular}{ccc} 
Outcoune & Probability & Expected Equity Value \\
\cline { 2 - 2 } & .1 & $\$ 33.00$ (retain) \\
$\# 2$ & .1 & $\$ 21.00$ (retain) \\
$\# 3$ & .3 & $\$ 15.60$ (rescind) \\
$\# 4$ & .5 & $\$ 15.60$ (rescind) \\
\hline 1.0 & & \\
\hline
\end{tabular}

Probability-Weighted

Average Equity Value .................... 17.88

184. The result of this benefit is that the expected value of the investor's holdings actually increases as a result of the fraud. Given the costs associated with asserting and collecting on any legal reinedy, however, the fraud will not often produce a net benefit for equityliolders. Still, equityholders should probably not be permitted to enjoy any best-of-both-worlds benefit, eveu if it exists only in theory, at the expense of contract creditors lield to their fixed claims. 
debentures and equity necessarily remain the same as computed under the assumption that the shareholders have no securities law remedies. ${ }^{185}$ The expected value of the debentures declines from $\$ 14.4$ million to $\$ 13.5$ million and the expected value of the equity plummets from $\$ 15.6$ million to $\$ 8.10$ million. Analyzed in terms of an allocation of the expected fraud loss between the debt and equity classes, the subordimation doctrine causes equity to bear $\$ 7.5$ million- $-89.3 \%$ of the total $\$ 8.4$ million expected loss-while debt bears only $\$ 0.9$ million$10.7 \%$. In terms of the present value of these securities at the time of purchase, the stock purchasers immediately lose $\$ .49$ of every dollar invested, compared to only $\$ .06$ of every dollar for the debenture purchasers.

\section{Table IV: Allocation of Expected Fraud Losses Under the SUBORDINATION DOCTRINE}

(millions of dollars)

\begin{tabular}{|c|c|c|c|c|}
\hline & $\begin{array}{c}\text { Expected } \\
\text { Value } \\
\text { Loss }\end{array}$ & $\begin{array}{l}\text { Present } \\
\text { Value } \\
\text { Loss }\end{array}$ & Allocation & $\begin{array}{c}\text { Loss per } \\
\text { Dollar Invested }\end{array}$ \\
\hline $\begin{array}{l}\text { Debentures } \\
\text { Stock }\end{array}$ & $\begin{array}{l}\$ 0.90 \\
\$ 7.50 \\
\end{array}$ & $\begin{array}{l}\$ 0.75 \\
\$ 6.25 \\
\end{array}$ & $\begin{array}{l}10.7 \% \\
89.3 \% \\
\end{array}$ & $\begin{array}{r}6.254 \\
49.084 \\
\end{array}$ \\
\hline IC As a Who & $\$ 8.40$ & $\$ 7.00$ & $100.0 \%$ & $28.00 €$ \\
\hline
\end{tabular}

Keep in mimd that this fraud loss remains separate and distinct from risks of business loss, risks also born principally by equity purchasers as traditional corporate law expeets. This may be illustrated as follows. If the worst case scenario, Outcome \#4; occurs, the total business loss is $\$ 9.6$ million-the true expected value of BIC, $\$ 21.6$ million, less its expected value under Outcome \#4, $\$ 12.0$ million-is placed on debtholders and equityholders in the amounts of $\$ 1.5$ million and $\$ 8.1$ million respectively. ${ }^{186}$ Adding the subordination doctrime makes equityholders lose a total of $\$ 15.60$ per share, composed of the $\$ 7.50$ fraud

185. This result occurs because the class of BIC's current equityholders and the clats of its securities law claimants are identical. Further, it assumes that the fraud remains hidden until the . end of the period. Suppose, for example, that Outcome \#4 occurs and the fraud is then detected. Under a subordination rule, whether the equityholders assert claims for deceit or for rescission, the holders of debentures are entitled to the full $\$ 12$ million-the same result as if no remedies existed. If, however, the fraud surfaces and the remedies are asserted earlier in the period, while the firm remains solvent, the result is clearly difierent.

186. Business loss as used here is the risk purchasers of BIC debentures and stock would have assumed if the true condition of the firm had been disclosed. As the fourth line from the bottom of Table III indicates, they would have paid for and received securities with expected values of $\$ 13.5$ million and $\$ 8.1$ million respectively. Under Outcome \#4, the full $\$ 12$ million would go to the debtholders resulting in respective losses of $\$ 1.5$ million and \$8.1 million. 
loss, incurred at purchase because of the less valuable investment opportunities they receive, plus the business loss of $\$ 8.10$ at the firm's demise.

\section{Table V: Allocation of Fraud and Business losses- OUTCOME \#4}

(millions of dollars)

\begin{tabular}{|c|c|c|c|c|}
\hline & $\begin{array}{l}\text { Expected } \\
\text { Fraud Loss }\end{array}$ & $\begin{array}{l}\text { Business } \\
\text { Loss }\end{array}$ & $\begin{array}{l}\text { Total } \\
\text { Loss }\end{array}$ & $\begin{array}{l}\text { Total Loss as } \\
\text { Percent of Investor's } \\
\text { Expected Values Before } \\
\text { the Fraud was Known }\end{array}$ \\
\hline $\begin{array}{l}\text { Debentures } \\
\text { Stock }\end{array}$ & $\begin{array}{l}\$ 0.90 \\
\$ 7.50\end{array}$ & $\begin{array}{l}\$ 1.50 \\
\$ 8.10 \\
\end{array}$ & $\begin{array}{l}\$ 2.40 \\
\$ 15.60 \\
\end{array}$ & $\begin{array}{r}16.7 \% \\
100.0 \% \\
\end{array}$ \\
\hline BIC As a Whole & $\$ 8.40$ & $\$ 9.60$ & $\$ 18.00$ & $60.0 \%$ \\
\hline
\end{tabular}

These conclusions belie any argument that, because both equityholders and creditors were defrauded, holding both classes to their contractual priorities should equalize the effect of the fraud. The BIC example demonstrates that because the subordination doctrine permits debtholders to participate in bankruptcy up to the full $\$ 15$ million face value of their claims, the effects are not equal. ${ }^{187}$ Instead, the subordination doctrine shifts the overwhelming portion of the risk of securities fraud to the junior securityholders in the interests of immunizing the senior class.

4. Results Under a Rule of Parity. Now consider the impact of a rule of parity on fraud loss allocation. If BIC becomes insolvent, a deceit remedy permits shareholders to assert claims totalling $\$ 7.5$ milhon in the bankruptcy. Under a parity rule, the firm's assets of $\$ 12$ million apply pro rata to these claims and the debenture claims of $\$ 15$ million, with the result that $\$ 8$ million goes to debtholders and $\$ 4$ million to equityholders. Rescission, in contrast, permits equityholders to assert a $\$ 15.6$ million claim if Outcoine \#4 occurs. If Outcoine \#3 occurs, the equityholders may also prefer to rescind because their rescission claim of $\$ 15.6$ million is greater than their residual equity claim of $\$ 9$ million. Thus, in Outcoine \#3, even though the firm's assets allow it to pay debtholders in full, a parity-plus-rescission rule will lead equi-

187. Even though the fraud does have an impact on the debentures because it increases by 2.5 times the probability of insolvency (Outcoine \#4), the debtholders receive soine antifraud protection through their entitlement to claim the full $\$ 15$ million face amount of their securities in the bankruptcy - an amount greater than the expected value of the debentures even for the firm as fraudulently represented. See Table III. This entitlement provides the debtholders with something akin to a "built-in" deceit claim, which serves to deflect most of the fraud loss to the equityholders, and will occur whenever the debt securities are issued or acquired at par or a discount. 
tyholders to rescind and assert claims rcndering the firm insolvent. The resulting distributions appear below:

\section{Table VI: Distributions in Rescission or Deceit Using a RUle OF PARITY \\ (millions of dollars)}

\begin{tabular}{|c|c|c|c|}
\hline & Outcome & $\begin{array}{l}\text { Distributions } \\
\text { to Debentures }\end{array}$ & $\begin{array}{l}\text { Distributions } \\
\text { to Equity }\end{array}$ \\
\hline Rescission & \#3 & $\$ 11.76$ & $\$ 12.24$ \\
\hline Rescission & $\# 4$ & $\$ 5.88$ & $\$ 6.12$ \\
\hline Deceit (Out-of-Pocket Damages) & \#4 & $\$ 8.00$ & $\$ 4.00$ \\
\hline
\end{tabular}

Not surprisingly, both rescission cases distribute more value to the equity than to the debentures because the face anount of the equityholders' rescission claim is greater than the debtholders' contract claim.

Tables VII and VIII further analyze the impact of these two remedies and the parity rule on the allocation of investinent value and fraud loss. ${ }^{188}$ Rescission-plus-parity would reallocate the $\$ 18$ million true beginning-of-period investinent value of BIC so that debtholders would receive ouly $\$ 7.89$ million while the equityholders would receive $\$ 10.11$ million-as opposed to the amounts of $\$ 11.25$ million and $\$ 6.75$ milhon, respectively, under the subordination rule. ${ }^{189}$ Deceit-plus-parity, on the other hand, produces a reallocation of $\$ 9.58$ million to debt and $\$ 8.42$ million to equity. These results confirm our earlier conclusion that rescission, not the parity rule, is the source of the best-of-bothworlds concern.

188. These tables are based on the distributions to the two classes under the four alternative outcomes, as set forth below. The numbers below reflect the actual distributions to each class; in cases in which the face amount of claims exceeds available assets, the face amounts of the claims appear in parenthesis.

\begin{tabular}{|c|c|c|c|c|c|}
\hline \multirow[b]{3}{*}{ Outcome } & \multicolumn{3}{|c|}{$\begin{array}{c}\text { Distributions } \\
\text { (millions of dollars) }\end{array}$} & & \\
\hline & \multirow[b]{2}{*}{ Probability } & \multicolumn{2}{|c|}{$\begin{array}{c}\text { Decert } \\
\text { (OUT-OF-POCKet DaMage }\end{array}$} & \multicolumn{2}{|c|}{ Rescission } \\
\hline & & Debentures & Equity & Debentures & Equity \\
\hline \#I & .1 & $\$ 15.0$ & $\$ 33.0$ & $\$ I 5.0$ & $\$ 33.0$ \\
\hline \#2 &.$I$ & $\$ 15.0$ & $\$ 21.0$ & \$I5.0 & $\$ 21.0$ \\
\hline$\# 3$ & 3 & $\$ 15.0$ & \$ 9.0 & SI1.76(\$15.0) & $S 12.24(\$ 15.6)$ \\
\hline$\# 4$ & 5 & S $8.0(\$ 15.0)$ & S 4.0657 .50 & S $5.88(\$ 15.0)$ & S $6.12(515.6)$ \\
\hline
\end{tabular}

189. See last line of Table III. 


\section{TABle VII: Reallocation of InVestment Value Through ANTIFRAUD REMEDIES (millions of dollars)}

\begin{tabular}{|c|c|c|c|}
\hline \multicolumn{4}{|c|}{ (millions of dollars) } \\
\hline Rescission & Firm as a Whole & Debentures & Equity \\
\hline BIC True Expected Value & $\$ 21.60$ & $\$ 9.47$ & $\$ 12.13$ \\
\hline BIC True Present Value & $\$ 18.00$ & $\$ 7.89$ & $\$ 10.11$ \\
\hline \multicolumn{4}{|c|}{ Deceit (Out-of-Pocket Damages) } \\
\hline B1C True Expected Value & $\$ 21.60$ & $\$ 11.50$ & $\$ 10.10$ \\
\hline BIC True Present Value & $\$ 18.00$ & $\$ 9.58$ & $\$ 8.42$ \\
\hline
\end{tabular}

In terms of the more important statistic, the allocation of expected fraud loss, Table VIII indicates that a coinbination of rescission and a parity rule would allocate the greater share of this loss (58.7\%) to debtholders. Measured by the present value of their securities at the time of purchase, the debtholders immediately lose $\$ .34$ on every dollar invested, but the equityholders lose only \$.22. A combination of deceit damages and parity, in contrast, shifts more of the expected fraud loss to debtholders than does the subordination rule, but equityholders still bear the greater share of this loss-about $66 \%$ of the whole, or $\$ .35$ on the dollar at the time they purchase their shares, compared to $\$ .20$ on the dollar for debtholders. ${ }^{190}$

190. These results also illustrate a point made in section B of Part II during the discussion of the reliance rationale. The section concluded that because of the collection of events necessary to trigger the benefits of the subordination doctrine, adoption of the parity rule would not typically alter the behavior of prospective lenders at the time of the credit decision. Suppose BIC's prospective investors believe that, despite their efforts to investigate BIC, sone material probability of fraud against thein remains. In theory, they could estimate this probability and take it into account in deternining how nuch to pay for BIC securities. The price of the securities will then reflect this "expected fraud discount" and investors will anticipate that by holding a diversified portfolio they can, on average, offset their occasional fraud losses with the collective discounts realized on all their purchases. To quantify this investor anticipation, assume that before any disclosures of the actual fraud, BIC investors estimate the probability of fraud at $10 \%$ and correctly predict the actual value of the firm if their suspicions prove accurate. Under the subordination rule, investors should then agree to pay $\$ 11.925$ million for the BIC debentures:

(millions of dollars; debenture values from Table III)

\begin{tabular}{|c|c|c|c|c|}
\hline & Probability & $x$ & Present Value of Debentures & $=$ Totals \\
\hline $\begin{array}{l}\text { No Fraud } \\
\text { With Fraud }\end{array}$ & $\begin{array}{l}0.9 \\
0.1\end{array}$ & $\begin{array}{l}x \\
x\end{array}$ & $\begin{array}{l}\$ 12 \\
\$ 11.25 \text { (subordination rule) }\end{array}$ & $\begin{array}{l}=\$ 10.8 \\
=\$ 1.125\end{array}$ \\
\hline
\end{tabular}

Combined Weighted Average-

$\$ 11.925$

Under the parity rule, on the other hand, provided securities law claims in bankruptcy are limited to out-of-pocket losses, the debenture purchasers would agree to pay $\$ 11.758$ million:

(millions of dollars; debenture values from Table III) 


\section{TABle VIII: Reallocation of Fraud Loss Through ANTIFraud REMEDIES}

\begin{tabular}{|c|c|c|c|c|}
\hline \multirow[b]{2}{*}{ Rescission } & \multicolumn{3}{|c|}{ (millions of dollars) } & \multirow[b]{2}{*}{$\begin{array}{l}\text { Expected Loss } \\
\text { Per Dollar } \\
\text { Invested }\end{array}$} \\
\hline & $\begin{array}{l}\text { Loss in } \\
\text { Expected } \\
\text { Value }\end{array}$ & $\begin{array}{c}\text { Loss in } \\
\text { Present } \\
\text { Value }\end{array}$ & Allocation & \\
\hline $\begin{array}{l}\text { Debentures } \\
\text { Equity }\end{array}$ & $\begin{array}{l}\$ 4.93 \\
\$ 3.47 \\
\end{array}$ & $\begin{array}{l}\$ 4.11 \\
\$ 2.89 \\
\end{array}$ & $\begin{array}{l}58.7 \% \\
41.3 \% \\
\end{array}$ & $\begin{array}{l}34.25 \notin \\
22.23 \uparrow \\
\end{array}$ \\
\hline Firm As A Whole & $\$ 8.40$ & $\$ 7.00$ & $100.00 \%$ & $28.00 €$ \\
\hline \multicolumn{5}{|c|}{ Deceit (Out-of-Pocket Damages) } \\
\hline $\begin{array}{l}\text { Debentures } \\
\text { Equity }\end{array}$ & $\begin{array}{l}\$ 2.90 \\
\$ 5.50\end{array}$ & $\begin{array}{l}\$ 2.42 \\
\$ 4.58 \\
\end{array}$ & $\begin{array}{l}34.5 \% \\
65.5 \%\end{array}$ & $\begin{array}{l}20.17 \uparrow \\
35.23 \uparrow\end{array}$ \\
\hline Firm As A Whole & $\$ 8.40$ & $\$ 7.00$ & $100.0 \%$ & 28.006 \\
\hline
\end{tabular}

Once illustrated in this manner, the deceit-plus-parity solution to the allocation of fraud loss of insolvency seems the most equitable.

\section{Some General Policies and the Allocation of Fraud-Caused Loss.}

Allowing shareholders to participate in bankruptcy as general creditors to the extent of their rescission claims causes contract creditors to bear the greater proportionate share of losses in investinent value caused by fraud. This solution to the bankruptcy probleen is, therefore, easily rejected. It is difficult, however, to find any sound policy basis for concentrating that loss almost exclusively on shareholders, the effect of a subordination doctrine. After all, no one consents to be defrauded or consciously assumes the risk of such loss. Given the absence of any truly consensual arrangement among investors governing allocations of the fraud loss, distributing it evenly would seein the fair-

\footnotetext{
\begin{tabular}{|c|c|c|c|c|}
\hline & Probability & $x$ & Present Value of Debentures & $=$ Totals \\
\hline $\begin{array}{l}\text { No Fraud } \\
\text { With Fraud }\end{array}$ & $\begin{array}{l}0.9 \\
0.1\end{array}$ & $\begin{array}{l}x \\
x\end{array}$ & $\begin{array}{l}\$ 12 \\
\$ 9.58 \text { (parity-plus- } \\
\text { deceit rule) }\end{array}$ & $\begin{array}{l}=\$ 10.8 \\
=\$ 0.958\end{array}$ \\
\hline
\end{tabular}

Combined Weighted Average-

$-\$ 11.758$

Thus, the parity rule reduces the present value of the debentures by only $\$ 167$ thousand or $1.4 \%-$ a one-time reduction in market value, not a reduction of $1.4 \%$ on the debentures' annual return. Furthermore, keep in mind that this is predicated on a $10 \%$ probability of a fraud that would overvalue BIC from $\$ 21.6$ million to $\$ 30$ million and create a $50 \%$ chance of default. Few reasonable investors would consider purchasing BIC deht securities given this prediction, whether a subordination or parity rule was in force. Reducing the estimated probability of fraud to, for example, one percent, which seems inuch more realistic, causes the parity rule to affect the expected value of the debentures by only $0.14 \%$ of their market value. Similarly, reducing the probability of default to a more realistic number-recall that even in the case of the hypothetical BIC firm this probability was set at a relatively high $20 \%$-further dilutes the effect.
} 
est solution, and a result consistent with the general bankruptcy dictates of parity. Indeed, several arguments may be advanced that such a result promotes sound corporate law policy.

1. The Policy of Shared Benefits and Risk Spreading. As discussed earlier, Slam and Kripke's response to this poimt argues that only creditors deserve special protection against the risk of fraud because they, unlike the shareholders, were not offered the stock. ${ }^{191}$ On a policy level, this position fails to acknowledge that the risk of fraud inheres in the issuer's access to the public capital inarkets, when investors necessarily lack open, firsthand access to information about the state of the issuer's financial affairs. All who deal with the public corporation, not just the purchasers of its common stocks, enjoy the benefits flowing from this market access. Indeed, the ability of the firm to use this access to expand its capital well beyond the limited personal resources of its entrepreneurs has been a crucial factor in the development of inodern large-scale corporations, froin which both institutional lenders and trade creditors alike derive substantial portions of their business opportunities. There should be nothing shocking, therefore, in having these creditors bear a portion of the resulting cost.

The BIC example demonstrates how allowing defrauded shareholders to participate as general creditors in bankruptcy to the extent of out-of-pocket damages acknowledges the societal costs of public markets by distributing fraud losses more broadly among all persons holding financial claims against a firm. ${ }^{192}$ Again, this risk is distinct from

191. Slain \& Kripke, supra note 44 , at 288 ; see also supra text accompanying notes $126 \& 146$. Slain and Kripke specifically contemplated only securities claims arising from the initial offering, but presumably wonld agree to extend their argument to claims based on open market transactions. These will probably be the source of most claims against an issuer. Trading market claims bear this distinction for three reasons: first, in the case of publicly held corporations, more investors acquire their securities in trading transactions than in primary or secondary offerings; second, new offerings registered under the 1933 Act likely present decreased risk of fraud because of the involvement and investigation by outsiders, such as underwriters, attorneys and accountants, stimulated by their exposure to hability under Section 11 of that Act, 15 U.S.C. \& 77k (1976); third, as a result of the reduced threshold of culpability under section 11 -the defendants' burden of establishing their own due diligence as opposed to the plaintifis' burden of establishing defeudants' scienter under rule $10 \mathrm{~b}-5$-the defrauded investors have a better chance to recover a substantial portion of their claims from outsiders and will rely less on the assets of the bankrupt issuer.

Particularly in these contexts, Slain and Kripke's point secms lost: shareholders cannot possibly deserve all the risk of fraud loss simply because they are the victims; or because "but for" their purchases, no securities violations could occur. In the BIC example, the debtholders and the shareholders purchased their securities under the infuence of the same inisstatements; there is, therefore, no obvious reason for distinguishing between the two classes on a causation basis.

192. The precise allocation of the fraud loss among the various classes will depend on all the facts, including the overall riskiness of the issuer's business, the relative amounts of debt and equity, and the magnitude of the fraud measured by its impact on the expeeted value of the issuer. in every case. however limiting shareholders to a deceit measure of damages should assure that 
risks of business loss, to which equityholders will still be exposed first. For example, in BIC's case, recall that the deceit-plus-parity combination of rules applied in insolvency would distribute $\$ 8$ million on the debentures and $\$ 4$ million on the equity. This allows a recovery of $\$ .556$ on the dollar by debtholders to $\$ .256$ on the dollar by equityliolders. ${ }^{193}$

2. The Policy of Optimal Loss Spreading. Spreading the expected fraud loss broadly has much to recommend it. The modern law of tort and vicarious liability embraces the wisdom of spreading and distributing risks of loss as a central tenet, reflecting a belief that the economic dislocation and personal suffering incurred when a smgle individual loses $\$ 10,000$ is typically greater than that incurred when 1000 individuals lose $\$ 10$ each. ${ }^{194}$ Neither the equity nor the creditor class approaches homogeneity. Although there are many large institutional equityholders, and small trade creditors and public debtholders, creditors are more likely to be "institutional" and, therefore, better able to redistribute the loss among their clientele than are sharelolders. At a minimum, the equity class of most public corporations will include

creditors will never bear a greater proportionate share of the loss; at most, their share per dollar invested will be equal. Although as yet unproven for all values, this point seems intuitively correct.

The recovery of any amounts from nonissuer defendants in the litigation may, however, distort the allocation of the total fraud loss among the classes. For example, suppose that a class action against BIC's former owners produces a settleinent of $\$ 4.4$ million, enough to pay in full both the remaining deceit claims of the equityloolders (\$7.5 million minus the $\mathbf{\$ 4 . 0}$ million recovered in the BIC reorganization) and the debtholders' deceit claims of $\$ 0.9$ million (see Table III). This leaves the debtholders bearing the full remaining amount of the fraud loss: the equityholders have recovered their out-of-pocket losses in full, but the debtholders have recovered a total of only $\$ 8.9$ million, considerably less than the $\$ 12$ million they would have received under even the most pessimistic outcome without fraud. To rectify this problem, the allocation in the class action must reflect the distribution in the reorganization. One effective way to do this is to subrogate the debtholders to the equitylolders' claims for amounts distributed in reorganization. Thus, in the class action the debtholders would have subrogation claims of \$4 million in addition to their $\$ 0.9$ million deceit claims, and would thereby receive $58.3 \%$ of the $\$ 4.4$ million settlement proceeds, or $\$ 2.57$ million. The equityholders would receive the remaining $\$ 1.83$ million. An alternative procedure for coordinating the recoveries in the reorganization and the class action was applied and upheld in the Equity Funding case. See Chemical Bank v. Confino (In re Equity Funding Corp. of America Securities Litigation), 603 F.2d 1353, 1363-67 (9th Cir. 1979).

193. The figures in the text reflect a recovery by the debentures of $\$ 8$ million on securities with an expected value of $\$ 14.4$ million, and by the equity of $\$ 4$ million on securities with an expected value of $\$ 15.6$ million.

194. See G. Calabresi, The Cost of Accidents, ch. 4 passim (1970) ("The justification found most often among legal writers today for allocation of accident losses on a nonfault basis is that accident losses will be least burdensoine if they are spread broadly among people and over time." Id at 39); P. ATIYAH, Vicarious LlabiLtTY in THE LAW OF TORTS 22-28 (1967); W. ProsSER, supra note 128, at 22-23, 459; Douglas, Vicarious Liability and Administration of Risk 1,38 YALE L.J. 584, 584-85 (1929); Laski, The Basis of Vicarious Liability, 26 YAle L.J. 105 (1916); Smith, Frolic and Detour (pt. 1), 23 CoLUM. L. REV. 444, 456 passim (1923). 
many individuals, such as present and former einployees, with savings and financial status closely linked to the fortunes of the issuer. Such individuals stand in an extremely poor position to bear the entire fraud loss on top of the business loss that inheres in their equity status. ${ }^{195}$

3. The Policy of Promoting Investor Confidence. Closely related to these concerns is the problem of investor confidence in the securities markets. Promoting such confidence has been an important policy goal of modern securities regulation. ${ }^{196}$ The failure of any large public corporation undermines that confidence, but spectacular fraud-related collapses such as those of Equity Funding, Westec, or Four Seasons carry with thein a special potential for harm. ${ }^{197}$ Many of the investors involved in such a collapse may exit feeling vulnerable to corporate insiders generally, and a cloud of suspicion may attach to similar companies. Telling the defrauded shareholders that they must shoulder the entire fraud loss so that large banks and other creditors may recover most of their loans will not advance any goal of restoring investor confidence. Admittedly, giving the shareholders twenty cents on the dollar for their losses under a rule of parity may not leave thein fully satisfied, but it is better than foreclosing their participation altogether, as would typically occur under the subordination doctrine.

195. The experience with the absolute priority rule demonstrates a tendency to preserve some participation for shareholders and other junior classes. Even in the face of strict contractual priorities that foreclose any doctrinal basis for doing so, reorganization plans have allowed junior classes, such as shareholders, to deflect a part of their business losses by participating in the reorganized bankrupt. The source of this flexibility is that the participation of eacl class necessarily depends on the value assigned to the securities it receives. In making this valuation under the absolute priority rule, courts have declined to use market value or "cash equivalency," instead computing an intrinsic or reorganization value based on capitalization of the debtor's projected future earnings. See Blum, The Law and Language of Corporate Reorganization, $17 \mathrm{U}$. CH. L. REv. 565, 566-83 (1950); Brudney, The Investment-Value Doctrine and Corporate Readjustments, 72 HARv. L. REv. 645, 672-75, 677-79 (1959). A considerable leeway exists in selecting the appropriate capitalization rate and estimating future earnings. This allows an opportunity, within limits, to choose values rationalizing the particular reorganization bargain struck by the classes. The higher the valuation of the debtor's securities as a whole, the greater the opportunity for junior classes to participate. See V. Brudney \& M. Chirelstein, Cases and Materials on CorpoRATE FINANCE 138-39 (2d ed. 1979) (citing various authorities for the proposition that consistent overvaluations occur in railroad reorganizations and, perhaps, in Chapter $X$ proceedings). In addition to the authorities cited by Brudney and Chirelstein, see E. ALTMAN, Corporate BankRUPTCY IN AMERICA 98-104 (Muntz TV reorganization), 113-20 (Green River Steel Corp. reorganization), 133 (common stockholders participated in 40 out of 90 reorganizations studied) (1971). But see Calkins, Corporate Reorganization Under Chopter $X-A$ Post-Mortem, J. FiN., June 1948, at 19.

196. See; e.g., Sargent, The SEC and the Individual Investor: Restoring His Confidence in the Market, 60 VA. L. REv. 553 (1974); Symposium, Insider Trading in Stocks, 21 Bus. Law. 1009, 1010 (1966) (remarks of William L. Cary).

197. See Sargent, supra note 196, at 583. 
4. The Policy of Private Fraud Deterrence. Further, by shifting some portion of fraud loss exposure to creditors, a parity rule inay promote the deterrence and detection of securities fraud. Once again, although sweeping generalizations about the relative institutional characteristics of creditors and shareholders may not always hold true, many creditors are in a better position than shareholders to protect against fraud. In the parlance of contemporary torts theory, creditors are generally the most efficient loss avoiders ${ }^{198}$ with respect to the risk of securities fraud. There are two reasons for this, both of which involve "monitoring costs." 199

First, large creditors have inore financial incentive to engage in monitoring activities such as review of the issuer's books and records and conversations with present and former managers. In theory, present and prospective financial claimants against the firm will engage in monitoring so long as the cost of monitoring remains less than the anticipated gam it produces for the claimant in reducing the claimant's expected risk of fraud loss. ${ }^{200}$ This necessarily bestows a competitive advantage on those with large claims or the means to coordinate the activities of several claimants so as to spread monitoring costs. Given the current state of corporate finance and the economics of lending, the claims of lenders tend to be more concentrated than the claims of shareholders. ${ }^{201}$ As a result, shifting some expected fraud loss to creditors, a class often likely to include institutions with large scale claimssuch as a lending consortium dealing with the issuer through a lead bank-202 should increase the overall level of monitoring. ${ }^{203}$

198. See generally, G. CALABRESI, supra note 194, at 135-73.

199. The term comes from Jensen \& Meckling, Theory of the Firm: Managerial Behavior, Agency Costs and Ownership Structure, 3 J. Fin. ECON. 305, 308 (1976).

200. This is essentially an extension of Judge learned Hand's famous $P, B$, and $L$ formulation of the duty of reasonable care in United States v. Carroll Towing Co., 159 F.2d 169 (2d Cir. 1947).

201. This is not true for all creditors. For example, trade creditors' holdings are probably no more concentrated than those of shareholders. Nevertheless, more concentrated claimants tend to belong to the creditor class.

202. A class of debtholders who possess the means to act collectively through an indenture trustee also fits this assumption. In practice, however, indenture trustees may tend to be more "passive" than direct lenders with respect to involvement in the issuer's affairs.

203. Some large-stakes claimants such as institutional investors, may reside among the issuer's shareholders as well, and shifting some fraud losses to creditors may appear to decrease the monitoring incentive of such large shareholders. For several reasons, however, this shift probably will not decrease these shareholders' overall level of beneficial inonitoring. First, even imder the rule of parity, such shareholders still bear a greater proportional share of expected fraud loss. Second, in few public corporations will the stakes of any single shareholder or coordinated group of shareholders equal that of the principal lenders. Third, if the institutional investors do detect a serious risk of fraud, their likely response under either a parity or subordination rule will be to evade the risk by selling their shares. This does little to directly reduce expected fraud losses-aside from the market effects of sales on the trading price of shares-it simply passes them on to others. 
Second, creditors-and more particularly lenders-probably possess better access to issuer information. Most shareholders can obtain only the issuer's pubhshed financial reports and the output of securities analysts. Lenders, on the other hand, can commonly bargain for contractual rights to deinand additional information from the borrower and to inspect its books, records, and facihities. ${ }^{204}$ Particularly if the financial condition of the borrower begins to deteriorate, the flow of financial information to lenders will typically go well beyond that available to the public or to most shareholders. ${ }^{205}$

Consider how these theoretical perspectives on monitoring inay work in practice. At the time of the initial securities offering, the creditor and shareholder classes probably have similar inonitorimg positions because most prospective shareholders, in effect, rely on the underwriters to perform the monitoring on their behalf. Underwriters have the financial incentive inherent in large-scale claims: they face liability under section 11 of the Securities Act up to the full offering price of the securities unless they can prove they diligently investigated the issuer's affairs. In addition, in the course of putting the offering together the managing underwriter will typically acquire a strong fauniliarity with the issuer's busmess and its prospects and will enjoy access to its books and records.

The disparity in monitorimg abilities arises after the distribution of the securities. In post-distribution trading, which includes the bulk of inost share transactions, the only direct monitoring on the shareholders' behalf occurs through securities analysts acting on public information and through the issuer's internal and outside auditors. Rule 10b-5 provides the basis for securities law liability in this setting and the rule requires that the defendant have acted with scienter. As a result, at this stage, there is no duty to investigate that can be enforced through shareholders' securities law remedies. In this context, lenders unight

Finally, in those cases in which particular shareholders do have stakes in the issuer greater than the lenders, they are likely to be directly involved in management. In that case, their incentives to monitor do not depend entirely on the expected fraud loss exposure of their holdings; their potential personal liability as aiders and abettors also provides some substantial incentives.

204. 'Rights of additional information and inspection are generally broader in the case of loans and privately placed debt than in the case of publicly held debt. See AMERICAN Bar Foundation, Commentaries on INDENTURes 328-40 (1971); Course Materials, ABA National Institute on Analyzing, Negotiating and Drafting Term Loan Agreements (N.Y. Sept. 2930, 1977) (discussion of financial and business information covenants); Nassberg, Loan Documentation: Basic But Crucial, 36 Bus. LAw. 843, 851, 894-97 (1981).

205. This supplies an additional reason why lenders will generally be in a more effective inonitoring position than shareholders: lenders can legally have access to nonpublic information. The issuer's selective disclosure of such information to its large institutional shareholders, on the other hand, would violate rule $10 \mathrm{~b}-5$. 
well acquire information that leads them to suspect that the issuer's financial condition is weaker than its public reports indicate. Until the issuer discloses the true picture its shares will continue to trade at inflated prices generating new securities law claims with each trade. A parity rule provides these lenders with a direct financial incentive, otherwise lacking, to act on their suspicions and, if true, to pressure the issuer into making corrective disclosures that will cut off the further competing securities law claims. ${ }^{206}$

\section{CONCLUSION}

The objective of this article has been to consider what, in theory, is the appropriate status for securities law claims in corporate bankruptcy. Part II examined the arguments traditionally tendered for subordinating these claims and concluded that, to the extent the claims represent compensation for the securityholder's out-of-pocket fraud losses, subordination is not justified. Part III concluded that allowing the securityholder to participate as a general creditor to the amount of these losses results in the fairest and the soundest allocation of the total fraud loss. In sum, no good reason supports the Bankruptcy Code's subordination treatment of securities law claims in section 510(b).

206. See, eg., In re Carter, SEC Release No. 34-17597, [1981 Transfer Binder] FED. SEC. L. REP. (CCH) I 82,847 (S.E.C. Feb. 28, 1982), in which the issuer's banks knew for several months that its disclosure of its deteriorating financial condition was inadequate. After the banks raised this issue with their counsel and the issuer's management, management disclosed the information. The bid price of the issuer's stock immediately fell from \$13 to \$3. 